\title{
The Tostan story: Breakthrough in Senegal ending female genital cutting
}

Population Council

Follow this and additional works at: https://knowledgecommons.popcouncil.org/departments_sbsr-rh

Part of the Community-Based Research Commons, Gender and Sexuality Commons, International Public Health Commons, Maternal and Child Health Commons, Obstetrics and Gynecology Commons, Public Health Education and Promotion Commons, and the Women's Health Commons How does access to this work benefit you? Let us know!

\section{Recommended Citation}

"The Tostan story: Breakthrough in Senegal ending female genital cutting," FRONTIERS Report. Cairo: Population Council, 2000. 


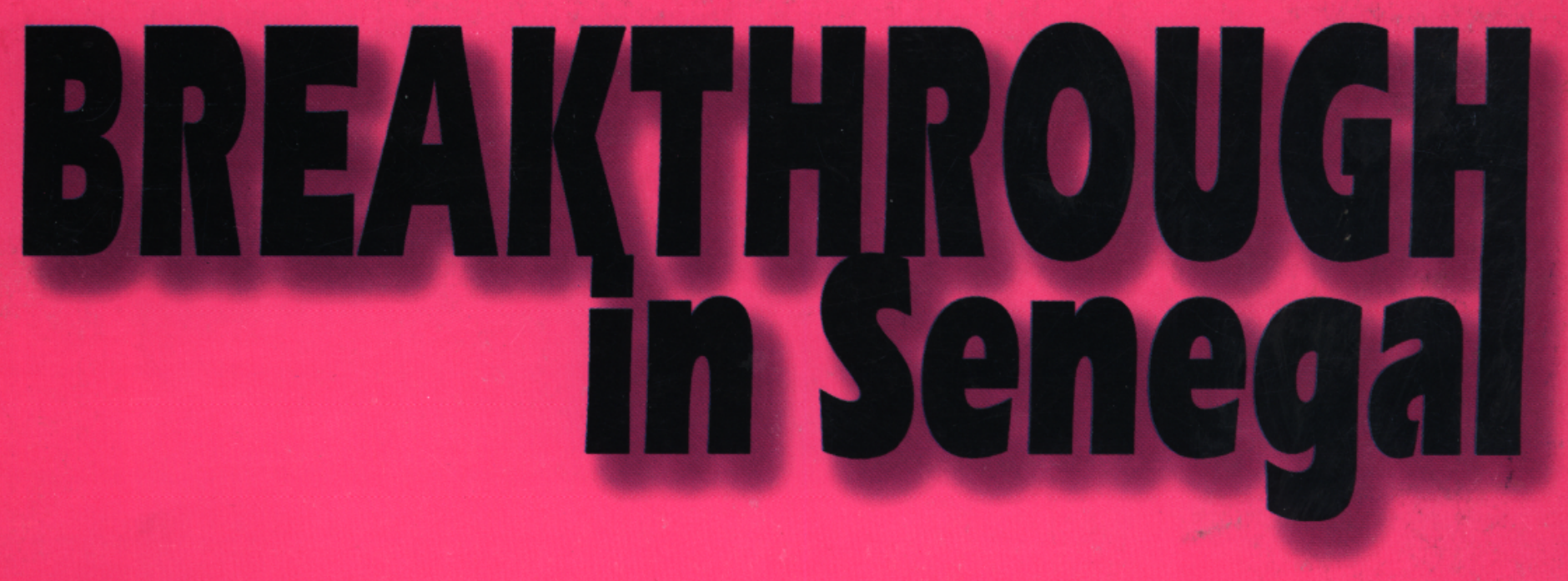

\section{ENDING}

female Genital Cutting

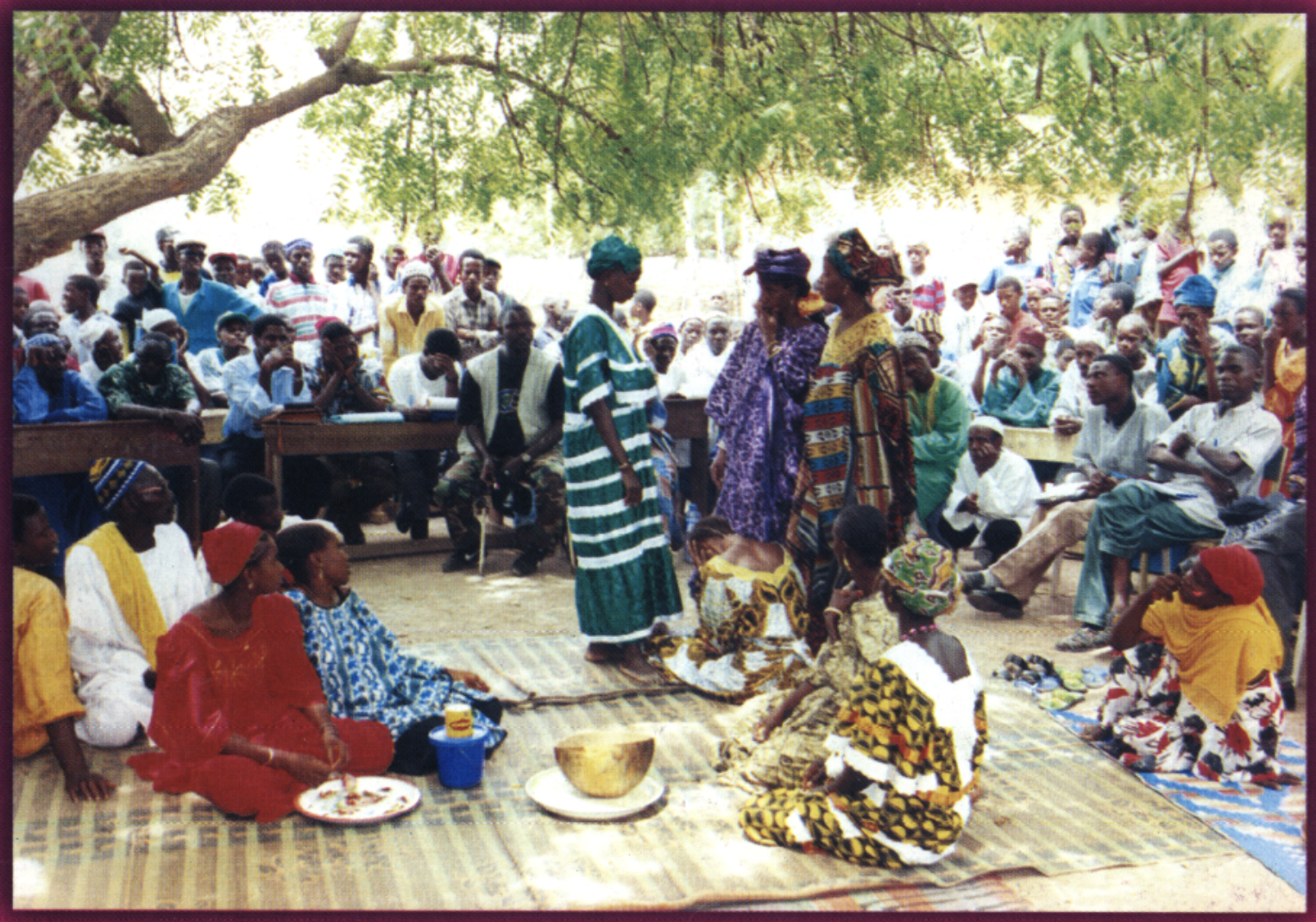




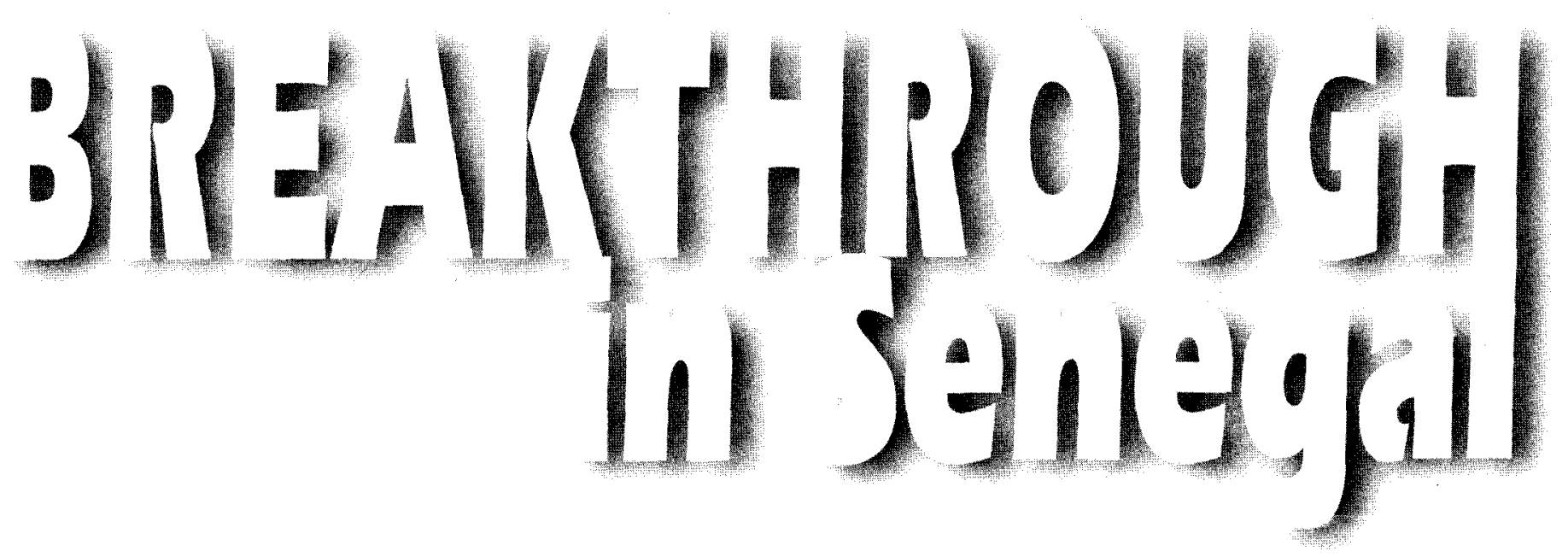

\section{THE PROCESS THAT ENDED Female Genital Cutting IN 31 VILLAGES}

Report Funded by : AFRICA OPERATION RESEARCH

\& TECHNICAL ASSISTANCE/PROJECT II POPULATION COUNCIL 


\section{ACKNOWLEDGMENTS}

Without the continued moral, intellectual and financial support of UNICEF Senegal over the past ten years, Tostan would never have been able to experiment and implement the Tostan basic education program. UNICEF received contributions from the Governments of Canada, Norway, the Netherlands and Germany to support the Tostan Women's and Girls' Education Programs.

We would also like to thank the American Jewish World Service (AJWS) which funded the development and implementation of Modules 7 and 8 of the Tostan program (1994-99).

USAID funded the educational training of 14 Non Governmental Organizations in the region of Kaolack (1987) and the experimental pilot program on "Non Formal Education in Rural Senegal" in Saam Njaay (1982-85).

The Wolof say: "Bu lëg lekkee alóom, war na gërëm coy." (If the hare is eating the fruit from the tree, he should thank the birds.) The positive results TOSTAN has achieved would not have been possible without the support of the following individuals: David Shear, Director of USAID Senegal from 1981-1985 who supported the beginnings of the TOSTAN program in the village of Saam Njaay and understood the importance of culture for development; Denis Caillaux, UNICEF Representative in Senegal from 1988-1990 whose vision propelled the program from dream to reality; Samir Sohby, UNICFF Representative in Senegal from 1990-1998 who greatly contributed to the program as he defended and navigated it through mercurial waters; Dr. Deborah Fredo from the Institute for Popular Education (IEP) in Mali who has enriched our program throughout the years; Professor Ndioro Ndiaye, Minister of Women, Children and Family (1987-95) who first requested the Tostan program; Aminata Tall, Minister of Literacy and the Promotion of National Languages (1990-93); Mamadou Ndoye, Minister of Basic Education (1993-98) and Aminata Mbengue Ndiaye, Minister of the Family, Social Action and National Solidarity.

Gerry Mackie provided great insight and innovative theory to our experiences related to ending Female Genital Cutting. Maître Sidiki Kaba and Shula Koenig reinforced our work in Human Rights Education.

President Abdou Diouf has fought for the end of Female Genital Cutting in Senegal by encouraging educational activities and public discussion in all villages. He vigorously promoted the recent law to end FGC.

TOSTAN would also like to thank Mrs. Hillary Rodham Clinton who is closely following the movement to end FGC and whose public support of the efforts of the men and women involved in this struggle have made an important difference.

An expression of deep gratitude goes to the late Professor Cheikh Anta Diop, spiritual father of the TOSTAN basic education program. His immeasurable contributions to the philosophy and development of our program have born fruit in hundreds of villages throughout Senegal.

TOSTAN would finally like to thank the Population Council for their support in helping us share our experience with others. 


\section{TABLE OF CONTENTS}

I. INTRODUCTION

II. PART ONE: THE TOSTAN PROGRAM

- $\quad$ THE TOSTAN BASIC EDUCATION PROGRAM MODULES 1-6

- THE TOSTAN CONTINUED EDUCATION PROGRAM MODULES 7 - 8

III. PART TWO: ENDING FGC IN 31 SENEGALESE VILLAGES

- A DESCRIPTION OF WHAT HAPPENED

- $\quad$ A TABLE OF EVENTS IN THE ENDING OF FEMALE GENITAL CUTTING IN 31 VILLAGES

IV. PART THREE: REFLECTING ON WHAT HAPPENED

- $\quad$ ELEMENTS FROM THE TOSTAN PROGRAM THAT LED TO THE END OF FEMALE GENITAL CUTTING IN THE 31 VILLAGES

- $\quad$ other factors CONTRIBUting to the END OF FGC

- LESSONS LEARNED FROM THE TOSTAN EXPERIENCE 
"In the Mandinka ethnic group, Ngir-Ngiro is a "rab", a spirit which attacks women who dare to break through the silence and speak of any suffering or negative effects related to their experience with Female Circumcision. In fact, women are told never to discuss anything related to what they have learned or undergone during this ceremony, the consequences being quite serious: for example, mental illness, paralysis, or even death. This is why women have never dared to speak about Female Circumcision, especially to someone who is not initiated.

I think the biggest merit of the TOSTAN education program is that the discussions in class and the public declarations helped to show women that Ngir-Ngiro doesn't exist any more and will not harm them as they once thought. Then breaking the silence allowed the women to understand the importance of ending this practice, a practice which, they learned to their surprise, is the source of suffering, psychological problems and death."

\author{
Daouda Ndiaye \\ Master of the "Juju" / Traditional healer \\ Specialist in Local Knowledge
}

"No, I have never heard of Ngir-Ngiro. But in fact we have other spirits similar to him in our traditions which have kept us Pulaar women silent throughout the years. In fact, I think women everywhere in the world have known some form of "Ngir-Ngiro" which keeps them from talking about troubling issues, don't you think so?"

\title{
Fatou Lala Baldé
}

President of the Women's Group

Medina Cherif 


\section{Introduction}

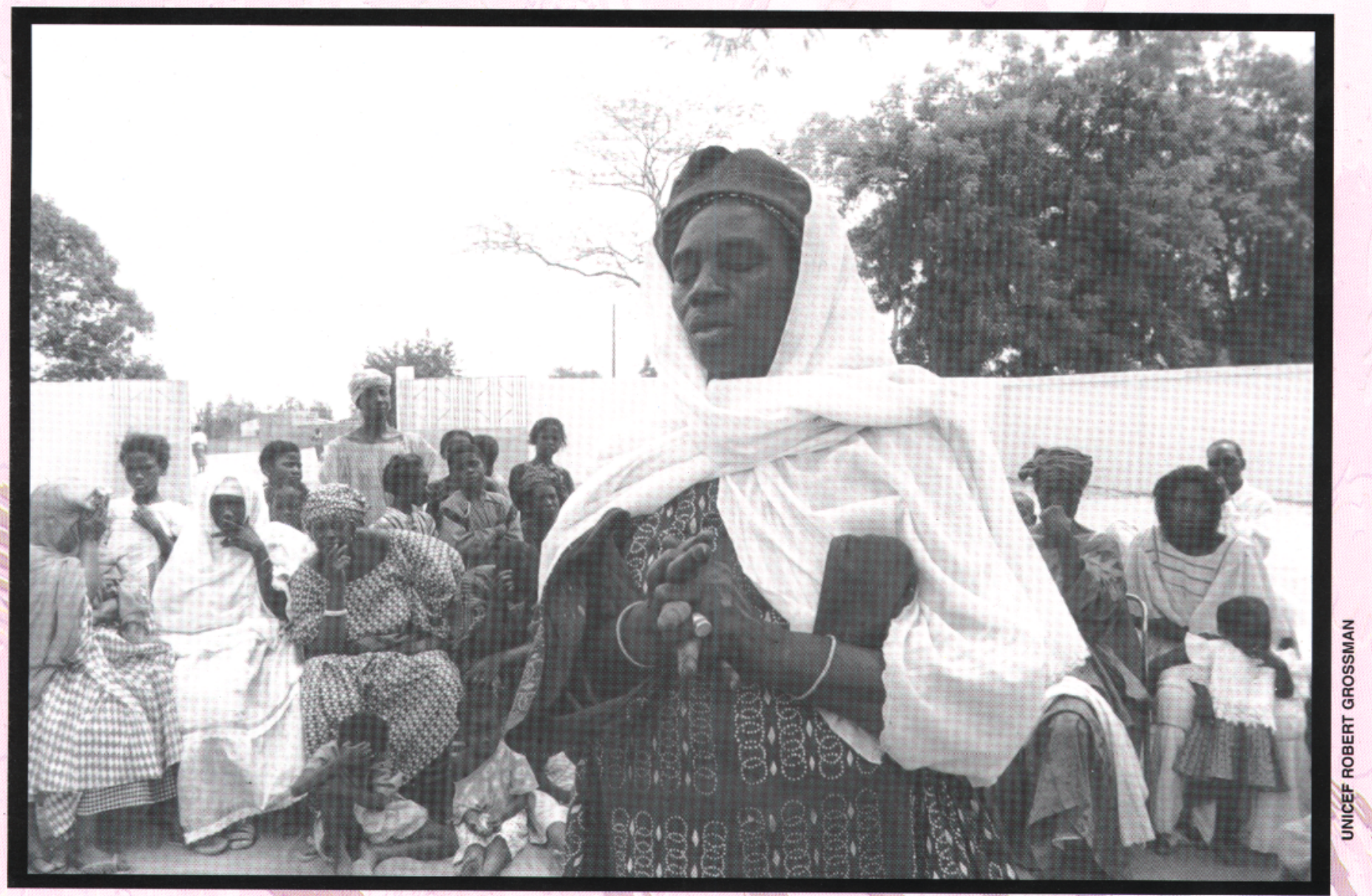

Maïmuna Traoré, President of the women's group at Malicounda Bambara makes a solemn appeal to villagers to promote girls' and women's health.

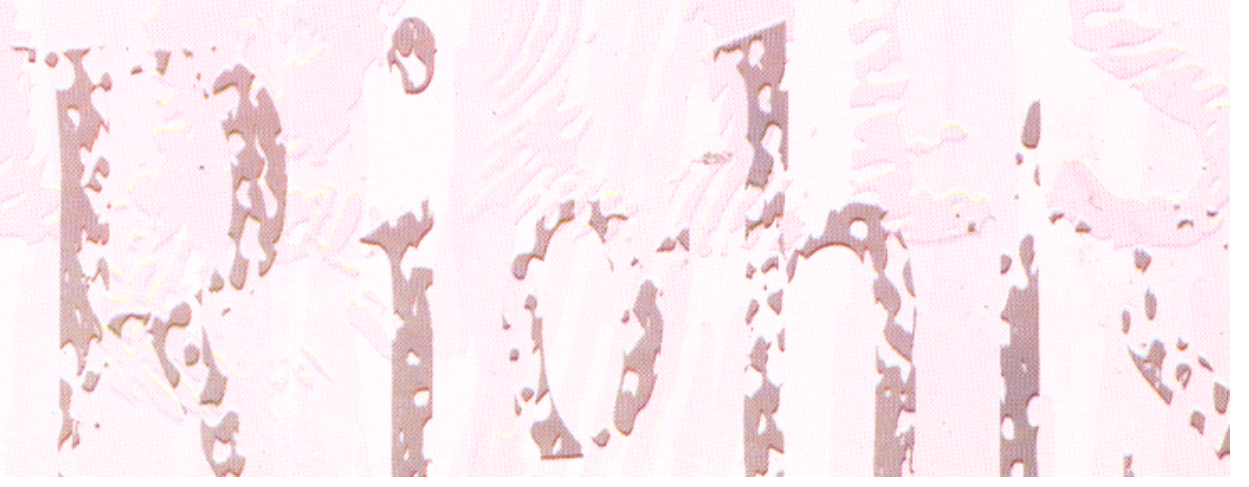


On July 31, 1997, forty determined village women invited twenty Senegalese journalists to the village of Malicounda Bambara to make an historic announcement. They, their husbands, the village chief and the religious leaders had made the decision to end the practice of Female Genital Cutting in their Bambara community. They made their decision, they explained, following the implementation of the Tostan basic education program in their village. They cited Human Rights Articles and talked of the negative consequences this practice can have on the health of girls and women. They performed a play in which a Bambara girl dies from hemorrhaging following the painful operation. They appealed to other villagers throughout Senegal to follow their example.

No one could have been more surprised upon first learning about their decision then Tostan, since ending Female Genital Cutting in communities practicing this tradition had not been one of the specific objectives of the education program. Yet this same decision quickly spread from Malicounda, to Nguerigne Bambara, to Keur Simbara, to 10 more villages in the region of Thiès and then to 18 villages in the region of Kolda. It soon became apparent that elements of the Tostan basic education program were indeed fundamental to the ending of this practice which has persisted for centuries, despite outside efforts over the past years to abolish such a dangerous and harmful operation.

This paper is an attempt by those who lived through these events to share the experience with others. Tostan believes it was the entire education program integrating cognitive, technical and psycho-social skills, which led to the pledge of Malicounda. We believe there can be no shortcut. To make this decision here, as well as elsewhere, women must have a sense of their own rights and those of all women. They must have confidence, self-respect and competence in the skills of decision-making and advocacy, as well as accurate health information. Therefore, in Part 1, the paper explains the Tostan education program before discussing the specific issue of Female Genital Cutting.

Part 2 is a description of what happened in the process of ending FGC in 31 Senegalese villages.

Part 3 analyzes the contributing factors in the villagers' decision to end FGC and indicates lessons learned from the Tostan experience.

At a time when there has been little reduction in the numbers of women ending Female Genital Cutting in 28 African countries, when different programs and strategies have rarely succeeded in making an impact on the number of women still practicing FGC despite laws abolishing the tradition, the Tostan experience does indeed represent a breakthrough. It is our hope that an understanding of the process described in this document will contribute to elaborating better and more positive strategies and actions for the future. There is also an added advantage: the education. 
program described has led to new leadership for thousands of women in rural areas, empowerment, increased democracy and a definite improvement of socio-economic conditions.

We have not attempted to make this a theoretical paper, but rather one that reflects the richness and intensity of the social transformations which Tostan witnessed and participated in over the past two years. It is dedicated to the courageous women of Malicounda who dared to break through the silence, to publicly say no, to choose health and life for a future generation of young African girls. 


\section{PART ONE}

\section{The Tostan Education}

\section{Program}

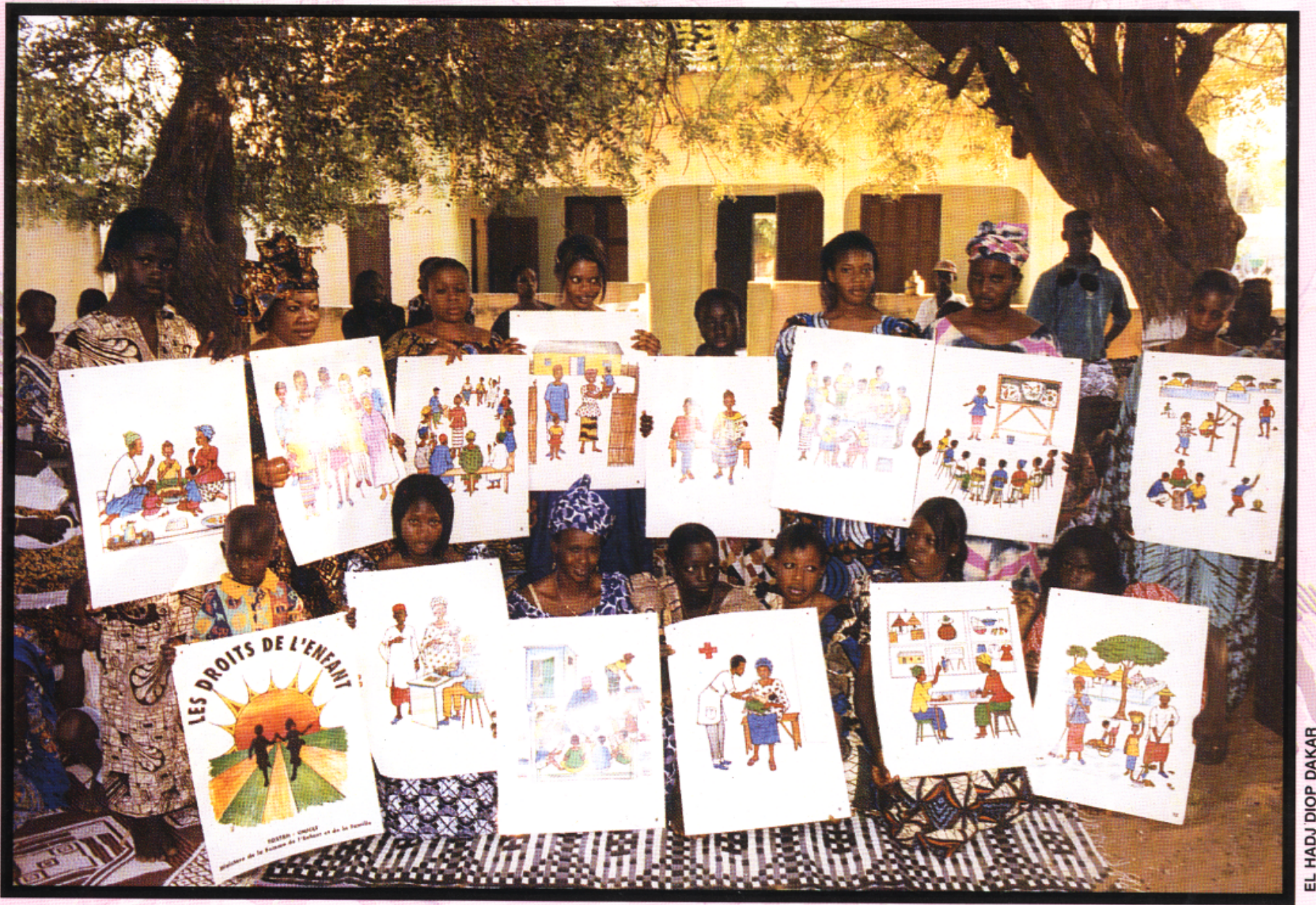

The class in Ngaparu displays the flip-charts Tostan developed for discussions on children's rights, Module 8.

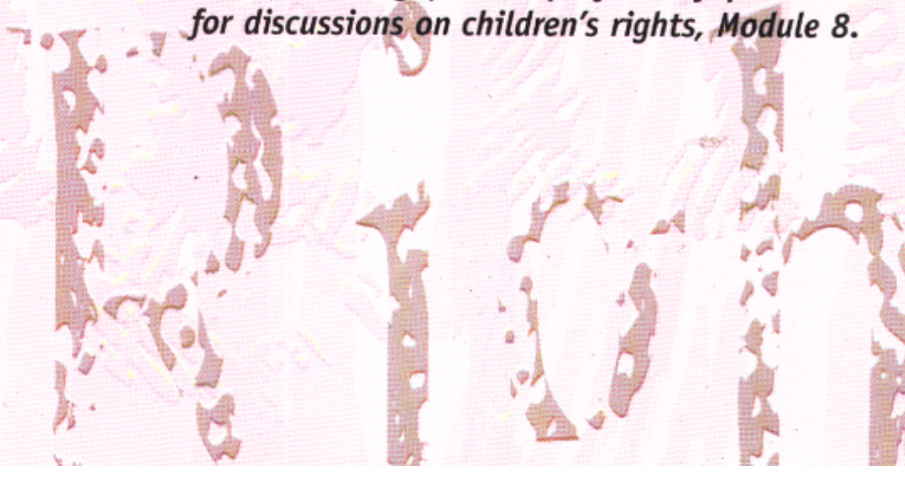




\section{THE TOSTAN BASIC EDUCATION PROGRAM: MODULES 1 THROUGH 6}

\section{INTRODUCTION TO THE PROGRAM}

Testan, which means Breakthrough in Wolof, is an international NonGovernmental Organization based in Senegal, West Africa. The Tostan education program includes a basic program of six modules and four continued education modules. It was developed with the philosophy that literacy skills alone are not sufficient to prepare learners for active participation in the social, political, economic and cultural decisions related to the development of their community and ultimately their country. Tostan therefore promotes an integrated approach to learning which offers a comprehensive curriculum in national languages not only for reading, writing, and math but also for improving life skills and the socio-economic conditions of participants. The use of innovative pedagogical techniques inspired by African traditions and local knowledge has contributed to making the sessions relevant, lively, and participatory. Tostan has now implemented both its adult and its adolescent program in more than 350 villages in nine different regions of Senegal and done training on the program for more than 25 Non-Governmental Organizations. The program has received excellent internal and external evaluations from educational experts and international organizations such as UNESCO, the Canadian International Development Agency, UNICEF, the Club du Sahel, and USAID.

\section{BACKGROUND OF THE PROGRAM}

The Tostan Basic Education Program has its roots in a center created for Senegalese children in 1976 - the "Demb ak Tey" (Yesterday and Today) Resource Center in Dakar. The goal of the center was to promote non-formal education for Senegalese children by giving them access to books, theater, puppetry, games and art activities based on their traditions and in the national language spoken by $71 \%$ of the population, Wolof. A Senegalese actor and specialist in oral traditions, Bollé Mbaye, and an American educator who had attended the University of Dakar and was working for the American Pcace Corps, Molly Melching, started the Center under the auspices of the Ministry of Culture of the Government of Senegal.

The Demb ak Tey Center expanded its activities to reach out to thousands of other Senegalese children with a two hour children's radio program in Wolof, aired weekly from 1978 through 1982. The major focus of the broadcast was children in rural Senegal, their activities and interests. Messages on health, the environment and other community development issues were included in the stories, songs, games, and theaters. This effort to give children access to more information and knowledge through use of cultural traditions was extremely popular. Both children and adults listened regularly to the program and used it as a forum for discussions in their villages.

Encouraged by these results and in an effort to expand on the idea of using 
cultural traditions for developmental and educational purposes, the Demb ak Tey Center moved in 1982 to a small village of 300 people, Saam Njaay, 10 kilometers from Thiès. The collaborative efforts of the villagers and the education team to improve living conditions in Saam Njaay led to what is now popularly termed "participatory development". Education classes became the force behind change in the community because they allowed all age groups to meet, discuss and find solutions to their particular problems. Learners used their reading and writing skills to do feasibility studies, write letters, and submit projects in Wolof, then successfully implement and manage them. From 1982 through 1985, many of these projects were funded and the villagers were involved in a process of problem-solving, participatory research, project planning, organization, management, and evaluation. By sharing and analyzing experiences, all participants in the project contributed to creating a major curriculum innovation for the teaching of literacy and community development in Africa.

Inspired from this experience, project originators developed a four-module program which was tested in 1987-8 in 42 villages in the Kaolack region in both the Wolof and Serer languages.

Then, with support from UNICEF and the Minister of Social Development, the team expanded the program to six modules from 1988 through 1991 and created an educational NGO in 1991 called Tostan which, in Wolof, means "Breakthrough". UNICEF and the Government of Senegal immediately recognized the potential of this new program in national languages to ensure a brighter future for Senegalese people, particularly women and children and in laying the foundations for a sustainable, "deeper" development.

The modules were rewritten and retested to better meet the needs of rural women and were implemented in Wolof, Pulaar, Serer and Mandinka to constitute a six module basic program.

\section{GOALS, OBJECTIVES AND STRATEGIES OF THE PROGRAM}

The program's goal is to improve the educational situation of villagers, particularly women, which consequently improves their living conditions and those of their children. Its objectives are:

a) to reduce illiteracy in Senegal;

b) to promote self-development through the use of adapted educational materials; and

c) to offer a model basic education program.

Four major strategies are considered necessary for achieving successful results :

\section{- A QUALITY COMPREHENSIVE EDUCATION PROGRAM} WITH AN INTEGRATED APPROACH TO LEARNING

No basic education program in national languages existed in Senegal in 1987. Although in the past many literacy projects were developed for teaching basic reading, 
writing and math, these were often implemented with insufficient teaching materials, training and supervision of teachers. Nonetheless, donor agencies and the government had spent large sums of money on literacy efforts during the 1970s and 1980s in the hope of reaching thousands of villagers. Unfortunately, few participants remained several months after classes began; those who did finish soon lost their new skills through disuse. Moreover, the literacy teaching was not being perpetuated by the newly literate with their illiterate neighbors and relatives.

Projects that did have some success in teaching the basic literacy skills soon ran up against new problems. While women were spending weeks learning the difference between "short a", "long a", and the "a with an accent", one out of every four children under five was dying in rural Senegal. As the educational specialist, Abdun Noor, pointed out in 1982: "Although literacy training is not interchangeable with basic education, many planners have conceived it as such. They have associated the need for literacy training with the objective of spreading developmental knowledge, when in fact they should have linked the need for a fuller, basic education with development. To this way of thinking, literacy training soon became an absolute prerequisite for acquiring knowledge that would lead to development. In the absence of a comprehensive, widespread motivation to acquire literacy skills, the literacy campaigns mounted by planners of this opinion turned into iron gates, barring the attainment of the developmental knowledge that the learner so urgently need for survival in an ever more highly competitive and economic world. This narrow view of education and development, albeit well intentioned, ultimately proved self-defeating." I

Tostan realized, then, the need for a comprehensive program that would simultaneously teach literacy and the "knowledge that would lead to development": for example, content that teaches essential life skills such as problem solving, health promotion, hygiene, women's health, child care, management, leadership, human rights, and natural resource management. Tostan sought to adapt the best educational methods and techniques and combine them in a quality program addressing the needs of a multitude of learners in rural Africa. Unlike functional literacy programs which link literacy content almost solely to specific occupational needs and the particular environment of the learner, the Tostan program was developed in a much wider context to reinforce any type of socio-economic activity leading to the well-being of the family and community.

\section{- A PROGRAM ACCESSIBLE TO WOMEN LEARNERS}

Both UNICEF and Tostan agreed it would be necessary to adapt the program to the specific needs and learning preferences of rural Senegalese women.

Ensuring that the program was appealing and relevant to rural women meant doing further research with learners to understand and reinforce Senegalese women's "ways of knowing and learning". It involved rewriting and retesting the program to take into account the fact that most village women have never been to primary school and are rarely exposed to letters and numbers in their environment.

\footnotetext{
${ }^{1}$ Noor, Abdun. 1982 Managing Adult Literacy Training, UNESCO. Prospects Quarterly Review of Education, Vol XII No, 2 . p. 165.
} 
The major subjects chosen as "basic" information were discussed with former female participants and often changed to better meet their needs.

The conception team also took into account that women all over the world learn better using an approach based on intimacy, narrative, nurturing, interdependence, and contextual thought. The vocabulary in national languages used by the women to describe their learning experiences and their perception of methodologies was integrated into the training guides and learners' books. ${ }^{2}$

Tostan also analyzed the 18 month time period for the program which provided that classes be held three times a week. Although longer than most literacy projects, the majority of village women maintained that coming to class every other day was essential to assuring sustained learning. Since most of them had never been to school, the day between classes allowed them the time needed to discuss, assimilate, and practice the new knowledge they learned during each two hour session. It also allowed a greater participation of women since the flexible time schedule allowed them to continue their other household and village activities. ${ }^{3}$

\section{- $\quad$ A PROGRAM WHICH COULD BE USED BY OTHER ORGANIZATIONS AND AFRICAN COUNTRIES}

To reach large numbers of participants, Tostan knew the curriculum would have to be easily accessible and comprehensible to all users. For this reason, detailed session guides were written in all national languages for trainers and village facilitators. Training seminars were provided for each of the modules, assuring practice and discussion of all the materials before their use. The Wolof, Pulaar, Mandinka and Serer languages were used for Senegal, but French and English editions will be necessary for other African countries interested in making adaptations of the program in their local languages.

\section{- $\quad$ A PARTICIPATORY APPROACH TO PROMOTE SELF- DEVELOPMENT}

"Participatory" was a key concept in the development and education vocabulary in 1988, but few projects actually put participatory theory into practice. While functional literacy helped people acquire better skills for carrying out specific tasks, rare were examples of literacy classes leading participants to critical analysis

\footnotetext{
${ }^{2}$ Much of this research was done by Deborah Fredo of the Center for International Education at the University of Massachusetts.

${ }^{3}$ The CIDA evaluation states: "The TOSTAN program is a complete program. After 18 months and six modules, the new literate has consolidated initial skills and is ready to continue training above and beyond the sphere of basic education. He or she can, if interested, at that point learn a new language or attend other trainings related to new themes." p. 68 "The TOSTAN methodology has turned out to be extremely adapted to the realitics of the milieu and to the learning rhythm of the villagers, both men and women." p. 74
} 
necessary for social transformation. Trainers would spend hours lecturing on how to be participatory as future village teachers sat in rows like school children, nodding off to sleep. Most of these teachers themselves had only several years of schooling. Without other models, guides, or stimulating materials, they could only apply the familiar passive and teacher-centered models in their own classrooms.

Tostan strove to create a basic education program which could help to empower villagers and assure equal access to information and resources at the community level. This was done through development of dynamic, interactive literacy materials for teachers and learners and use of cultural traditions. It meant creating truly participatory curriculum and training methods for trainers, village facilitators, and learners. Experience with the program had shown that village facilitators needed a well-tested, research-action oriented curriculum presenting examples of different participatory techniques. From this curriculum, facilitators were eventually able to create theory by extracting and analyzing the different pedagogical processes they found most successful in their classes. Through further participatory research with learners, they were then able to apply these theories to create new materials and approaches in order to address other issues relevant to the villagers, helping to transform the local environment.

\section{PROGRAM CONTENT, METHODOLOGY, AND ORGANIZATION}

\section{- PROGRAM CONTENT: MODULES 1 THROUGH 6}

The content of each of the six modules of the basic program was chosen in collaboration with former learners, particularly women, and with constant reference to the basic needs of Senegalese villagers throughout the country. Studies of rural Senegal indicated that problems of water, health, hygiene, the environment and rural migration were the priority issues confronting the majority of the populations. ${ }^{4}$ The villagers not only wanted to discuss these issues, they also needed technical information presented in a way that would help them make decisions and find solutions to these problems.

Thus, problem-solving skills are introduced in Module 1 so that participants can continually use them throughout the program. Learners master a basic process through use of examples, drawings and games. This process involves:

1. identifying and analyzing the problem

2. studying adapted solutions (based on available financial, material and human resources, as well as the time factor)

3. planning the solution (what activities need to be accomplished? for each activity : when does it need to be completed? who is responsible? what human, material and financial resources are necessary? and what are the possible obstacles?

4. implementing the solution

5. cvaluating the results - did we eliminate the problem?

\footnotetext{
${ }^{4}$ UNICEF and the Government of Senegal, 1991. Analyse de la Situation de la Femme et de l'Enfant au Sénégal,
} 
The pre-literacy book in Module 1 allows learners to practice reading and writing skills and reinforces the discussions of each session. The participants also learn to read, write and analyze numbers one through nine. They are indirectly introduced to addition and subtraction through the use of sets, helping to build a base for learning more advanced math operations in Module 2. The math workbook they receive is used from Modules 1 through 5.

In Module 2, participants learn technical information about the transmission of germs and the positive effects of good personal and village hygiene, then actually practice the problem-solving process in relation to hygiene in their own village. Small groups from the class form research teams to identify and analyze the major health and hygiene problems of their area and logether seek solutions to the problem. They implement the solutions using their own resources and then, together, evaluate the results.

Participants receive a reading book in Module 2 with texts that reinforce the theme for the module. This book is used from Modules 2 through 4 . Learners also begin to analyze the sentences, words, syllables, and letters of the texts. They receive and read an illustrated health booklet on the transmission of germs. In math, they learn addition and subtraction as well as large numbers.

Module 3 introduces pertinent health information relating to the two major causes of death in children under 5: dehydration and illnesses resulting from lack of immunization. Social mobilization activities assure that the learning process remains active and relevant to their environment.

Participants continue the reading process, always beginning and ending their Iessons with the study of text. They also receive two health booklets on the Oral Rehydration Solution and Immunizations. At the end of Module 3, the learners are able to do addition and subtraction with carry-over.

Module 4 teaches basic financial and material management for all types of village projects. This module is introduced at a time when learners have already assimilated the math and literacy notions necessary to fill out the documents involved in good bookkeeping.

Participants finish their reading book and the analysis of the letters of the alphabet in Module 4. Multiplication skills are introduced during this module.

In Module 5, learners discuss notions of leadership and group dynamics. Through lively case studies related to their own experiences, they reflect on traditional leadership and ways to bring about effective changes for the future.

During the fifth module, the participants learn a "writing process", which helps them to demystify the act of producing a text. Working alone or with partners, learners create a variety of texts including letters, newspaper articles, projects, poetry and short stories. The "writers' workshop" held every two weeks is an exciting activity for the participants as they "make public" their works. This process also deepens the participants knowledge of the grammar, orthography and punctuation of their language.

In math, learners review their math skills through solving concrete word problems, but also learn division.

Module 6 helps villagers in making decisions for income-generating or other types of projects for their village groups. Using games, flip charts and theaters, the participants understand the need for feasibility studies before undertaking projects that 
could lead to economic disaster.

All math and reading skills are used by participants when they choose and do their feasibility studies.

\section{- PROGRAM METHODOLOGY}

\section{Reading and Writing Approaches}

In many literacy projects in Senegal and West Africa, the literacy session involves village educators leading a discussion on an issue of interest to the villagers, then having the learners summarize the discussion with a sentence. Afterwards, the teacher focuses on a key word in the sentence, then a syllable, and finally the letter to be learned that session. Most teachers, influenced by traditional methods of teaching reading and lacking stimulating curriculum guides, spend long periods in the classroom working on letter repetition and syllable combination. In most of these projects, no real reading takes place until months after the project begins. ${ }^{5}$ This method for teaching reading skills has a major disadvantage: it focuses on sounds and letters (or syllables) which are abstractions and have no meaning to participants.

Tostan educators found that women in particular had a great deal of trouble when letter repetition and syllable combination were emphasized. During evaluations, participants were so busy deciphering letters, they had no idea what the text meant, even though it was written in their mother tongue. Word recognition methods also had the disadvantage of isolating elements of text and not teaching language as the women have spoken it all their lives.

For these reasons, Tostan decided to expand on and enrich the literacy methods experimented with in Saam Njaay where almost no emphasis was put on phonics. The method used is influenced by a "whole language" approach in which the participans. first understand what text is by being exposed to real texts, not just isolated fragments of language such as words and syllables. Learners also participate from the beginning in creating texts, then are able to read them because they are familiar with the content.

Eventually, however, the villagers also learn to "decode" through non-formal techniques such as learning an alphabet song, much like alphabet songs of other countries. The rhythmic music is adapted from traditional African songs. Because participants have already read text and words when they learn the song, auditory perception and discrimination of letters soon follow. They use a mixed reading method from Modules 2 through 4, which combines the whole language approach with the study of sentences, words, syllables, and letters.

The focus in reading sessions however is always on comprehension. During Module 1, learners are read to during each session and themselves create and read texts. At Tostan, "post-literacy", begins on the first day of class! Learners are also exposed to books from the beginning sessions. Thus, motivation plays an important role in the learning process as they quickly understand the goal of literacy learning.

Writing is introduced in the beginning sessions, first through pre-literacy skills

\footnotetext{
${ }^{5}$ See Melching, Molly, 1986. Evaluation of the 1985 ENEA/Cooperatives Literacy Project,. A Report to USAID/Senegal.
} 
and then by writing meaningful words and text. By the end of the first module, learners can read and write their names, the name of their village, and have even written correspondence with the help of the facilitator!

With these methods, the majority of participants are able to read and write fluently by the end of the third or fourth module. ${ }^{6}$

\section{Math methods}

The sessions used to teach numeration and basic math skills were adapted from methods introduced at the Institute of National Languages in Mauritania. This Institute was created in 1979 with the goal of introducing national languages to the educational system. Their approach to teaching math was innovative because it placed great emphasis on mathematical language and logic. Thus, the notion of "base" as the foundation of all written or oral numeration was introduced from the beginning sessions. The study of "base 10" allowed participants to understand the first step in math learning: using the concrete (objects) to understand the semi-abstract (drawing of the objects used) and the abstract (numbers). This, in fact, is a well-known pedagogical principle in math teaching which normally should be practiced at all stages of written numeration and for the four basic math operations - addition, subtraction, multiplication and division. However, this important process is often ignored in many math programs as the learner tries to assimilate new concepts.

Tostan did further research in theory and practice based on the Mauritanian experience. On a theoretical level, Tostan trainers studied local knowledge of counting and math in the Senegalese environment, compared written and oral numeration. studied problems of syntax in oral numeration and their transposition in written numeration, and developed a connection between numeration using base 10 . Participants learn math using the three important steps of math learning : the concrete, the semi-abstract, and the abstract. ${ }^{7}$

On a practical level, Tostan adapted the math method to the rural environment and particularly sought to facilitate math learning for women. The detailed session guides cover all four basic math operations including multiplication and division. Each module includes 10 math sessions. and moves from counting and the meaning of addition and subtraction in Module 1 to the more difficult skills in each consecutive module. The math lessons are always tied to practical skills needed for community development. For example, after the learners master numbers from 10 to 100 ) (using base 10) in Module 2, they immediately learn how to use the calendar and tell time. At this point, the community develop agents working on project implementation in the village encourage learners to practice their new skills outside the classroom by asking them to plan activities using agendas and calendars. Tostan also incorporated math games conceived and tested in villages to encourage frequent practice of basic concepts.

\footnotetext{
${ }^{6}$ The CIDA evaluation states: "Despite differing levels of the facilitators, we nonetheless observed the capacity of all participants to read in their national language and to do the math operations corresponding to the advancement of the math programme in their center." (Evaluation done before the end of Module 3 in all classes) p. 4 !.

7Bah, Amadou. 1993. An Introduction to the TOSTAN Numeray'

Methodology. A report submitted to UNICEF.
} 


\section{Presenting Community Development Themes}

Methods for teaching most subjects presented in the Tostan program was inspired by the experience of trainers and learners at the Demb ak Tey Center and in the village of Saam Njaay. The pedagogical premise of a given subject is that villagers first need to: a) look at and analyze what they or other villagers are doing now and understand why they are doing it in a non-judgmental manner; b) receive new, relevant and often technical information in a way they can comprehend the message; c) work as a group to process the information and decide if it is relevant to or can improve their situation. Never are the villagers told what to do; they are, however, given pertinent knowledge that will allow them to make intelligent, informed decisions.

This knowledge is presented using traditional forms of African culture including proverbs, stories, theaters, games and songs. Often, several steps using diverse participatory techniques are involved in the learning process:

Step 1 - Becoming familiar with the new information. Technical knowledge presented in a way that learners can understand.

Colorful flip charts, pictures, participants' stories, theaters, or songs are used to encourage assimilation of new knowledge during the first sessions when a subject is presented. Participants discuss their ideas about the topic and the facilitator involves the participant in the learning process through constant reference to their own experiences. There is in-depth presentation of new technical information which can help give participants much of the information they need to make intelligent decisions. Facilitators encourage in-depth dialogue among the participants to assure that differing opinions may be aired. Superstitions and traditional beliefs related to the subject are brought up and discussed openly.

\section{Step 2 - Reinforcing the new knowiedge}

During the next learning sessions, participants review and better assimilate the new information learned through games or theater.

\section{Step 3 - Using literacy skills to reinforce knowledge}

Participants receive books or write articles, stories, poems or songs discussing what they have learned. Because they are familiar with the information, it is easier for them to read and write texts.

\section{Step 4 - Making a difference in the community}

During the following sessions, learners plan strategies for helping to assure that their new knowledge be shared in the community and put into practice. They analyze obstacles to achieving positive social transformation and identify key actors in the process. They also may role play to practice their advocacy skills with other members of the community or government officials.

\section{Step 5 - Sharing the knowledge with others - Learners become facilitators}

The participants learn to present the new information themselves by using the flip-charts, theaters or other images. They are then encouraged to present the flip chart to members of their family, neighborhood organizations, or in other villages. 
They also are encouraged to read and discuss their books or the texts they have written with many other people. This fifth step leads to a sense of empowerment on the part of the learners who suddenly realize that they are capable of communicating important, life-saving messages using techniques which capture the interest of their audience. They demystify the role of the teacher and grasp the fact that they also can make an important difference in their environment. This gives them the confidence to identify other problems of the community and develop new materials for solving those problems.

\section{Using Social Mobilization Activities}

Tostan also realized the importance of using social mobilization activities to reinforce the education classes. One village facilitator, for example, is a local religious leader and president of the association of imams (religious leaders of the Muslim religion) in his arca. His strong belicf in education for development has led him to organize meetings and educational activities in other Tostan villages to reinforce the idea that learning in local languages is a positive force in rural Senegal. Because he is a highly respected individual, people respond with great enthusiasm to his visits.

Tostan has sponsored theater, poetry and debate sessions in national languages in many villages. Traditional musicians, singers, poets and actors have visited classes to recite poetry or present plays in national languages, then lead discussions on the often controversial messages of the plays or poems. Villagers attend the sessions in great numbers. As one village father declared: "After listening to several poems, I knew I was going to have to change!"

Public debate and deliberation on class issues is essential to bringing about social transformation at the community level. For this reason, social mobilization activities are necessary as follow-up to class learning.

\section{Evaluation Methodology}

\section{Baseline studies}

Before beginning an education program within a community, Tostan implements a base-line study in collaboration with a significant number of the members of the community in order to establish a reference for comparison at the end of the program.

\section{The management information system}

Important information on the development of the program is organized in a system which allows evaluators to store and easily provide information to decision makers in the program. This information is collected throughout the modules of the program. The system consists of monthly standardized forms which are filled out by facilitators, trainers, and coordinators. They also complete evaluation tables for the different modules with an assessment of student progress. These sheets include questions such as: How many participants are in the program? How many participants are at level 0 or 1 (the lowest levels) at the beginning of the program? How many participants are men and how many women? Where do participants live and work? What are their test scores? Did anyone drop out during the module? If so, why? etc.

The information gathered from these questionnaires allow the staff and trainers to react rapidly to solve any problems related to absences or poor results in a 
given area (math, reading, themes, etc.).

\section{Naturalistic evaluation}

As a substitute for more formal models of program evaluation, Tostan also uses a "naturalistic" approach which takes into account the values of the participants since these values will be used as the criteria for making judgments. Also, the structure used to collect and analyze the information may change during the evaluation process. This evaluation is closer in spirit and approach to Tostan philosophy since it gives a better indication of how the participants themselves are experiencing the program. In group interviews, for example, learners evaluate the training modules, the content, the pedagogical approach and the materials used. These assessments help participants understand that the program is for them, thus their feedback is crucial to program designers. As Janet Kelly comments: "One great motivator, especially in something as challenging as adult basic education, is for learners to clearly see and feel their own growth. Standardized tests do not measure growth in self-esteem, life skills, empowerment, community involvement, and self-confidence, nor do they truly measure the literacy skills that adult learners make in many programs." 8 Thus, the structured or non-structured group discussions allow participants to reflect on their own behavioral changes as well as changes brought about in their homes or environment due to their new knowledge and activities. The anecdotes related by participants are particularly important as they often reveal important changes in attitude or behavior.

Tosian also asks the facilitators and trainers to observe and record their impressions of learners' progress as much as possible. The trainers in one region decided, on their own, to interview people from other villages surrounding the Tostan class villages to find out their impressions of program impact on the neighboring villagers.

Each participant is also interviewed individually in order to check on his or her progress during the module. This evaluation tool may serve, aside from assessment needs, as a means to gather stories related to learning. Finally, the evaluators themselves become evaluation tools since they are in constant interaction with the milieu and the learners. The evaluators try to be creative and imaginative, and invite the participants to be so as well.

Since the Tostan program uses a pedagogical approach based on specific objectives for each module, it is quite easy to administer short "tests" at the end of each module. The students are not "graded", as a grading system can negatively effect the motivation and morale of the adult learner. Rather they participate in an assessment of their work with the trainer and facilitator present to evaluate if the objectives set are "achieved", "in progress", or "not achieved".

When the class results are presented to the trainers, facilitators, and participants, it serves as a basis for a sharing of ideas as to why there are certain problems, how to overcome them, and what new goals learners want to set for themselves and the class for the upcoming module. Thus, the "summative" evaluations for each module become "formative" evaluations which allow for midstream monitoring and at the same time encourage trainers, facilitators and participants to do assessments on a regular basis.

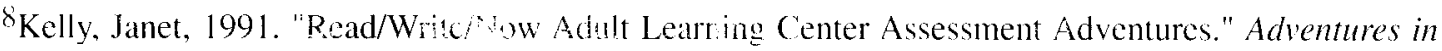
Assessment, Volume Y. SABES. P. 17.
} 


\section{- PROGRAM ORGANIZATION}

The Tostan Basic Education Program includes six modules of learning. Each module covers 24 sessions and lasts two months. Each session is designed to last approximately two hours. Based on their work schedules, the learners choose the days and time when they will meet for class, but normally most classes meet 3 times a week, every other day. In the second class session, they also establish their own rules for the way in which the classes should be organized and together define the role of the facilitator and learners. The objectives for the program are outlined during the first class session and the objectives for each module are also discussed before each module. During the rainy season, learners generally only meet once or twice a week but during the dry season ( 8 months of the year), many classes create study groups to meet outside of their 6 hours of class sessions to review and practice new information.

After the trainings held before each module, the trainer makes regular visits to the classes in the villages to which he has been assigned. One trainer can normally cover 10 to 13 villages located close to one another. The trainer helps village facilitators review the sessions for the upcoming week and attends classes to assure there are no major problems. He or she meets with local development agents to coordinate class subjects and project activities, as well as local authorities from the government.

\section{The Village Facilitators}

The village facilitators are always chosen by the community of participants based on specific criteria established by Tostan and former learners:

- The facilitators should have at least four years of primary school or already be literate in national languages.

- The facilitator must be available in the village during the week and for the 18 month period of the program.

- The facilitator should be patient, tolerant, respectful of others, competent, and devoted to learning.

The facilitators either receive an honorarium of approximately $\$ 100$ per module (which can last from 2 to 3 months) or are remunerated in some way by the village group.

\section{Training}

The facilitators receive extensive training before each module offered in the program. Module 1 training lasts for one month and covers the following areas:

\section{Orientation to Tostan and the basic non-formal village education program}

Providing the facilitator with information needed to understand her or his role in the Tostan organization and to become familiar with all aspects of the non-formal education program. Includes an introduction to Tostan's evaluation component.

\section{Local knowledge}

Systematizing facilitator and learner knowledge for authentic dialogue and relevant materials development. 


\section{Perfecting written language}

Enabling facilitators to learn transcription skills in national languages and to expand their awareness of the structure and uses of written language. Encouraging writing as a tool for their own continuing education and for development of new literacy materials and practice.

\section{Participatory approaches to adult education}

Encouraging facilitators to be aware of the educational environment in which the literacy class is taking place, to distinguish the different forms of education in Senegal and their different goals, to identify the particular goals of a national language non-formal education program and to develop skills in creating an environment conducive to the education of adults for self-initiated community development.

\section{Creating a literate environment: becoming readers and writers}

Guiding facilitators to reflect on what reading and writing is and encouraging them to do both. Analyzing what good readers do and how the Tostan program teaches reading in national languages. Linking reading to writing by producing texts and "publishing" facilitators" writing.

\section{Understanding numbers and how we use them}

Introducing facilitators to the "logic" of mathematics, explaining the overall theory of math learning in the Tostan program and basic procedures for math sessions.

\section{Practicing facilitation of the Tostan Module}

Preparing facilitators to use the session guides for the module, to practice facilitation skills called for in the sessions and to understand the overall design of Tostan's non-formal education program.

The trainings for the following five modules are much shorter, usually 10 to 12 days, and always anticipate the upcoming module, and review all of the components.

\section{ACHIEVEMENTS OF THE PROGRAM}

\section{- DEVIELOPMENT AND PUBLICATION OF PEDAGOGICAL MATERIALS}

-Production of ten modules (six moduies in the basic program and four continued educatici. modules) for the Adult Education Program and six modules for the Adolescent Education Program. This includes 16 detailed guides ( 100 to 150 pages each) for facilitators for each module as well as 12 participant books in major national lainguages:

-Bools of pet y, stories and thuater for readers:

-Flip-ciarts with zuides in national languages on subjects relating to health, human rights, entrepre aeurship and early unildhood development;

-Pedagogical games for adult and adolssent !e orners. 


\section{- TRAINING FOR TRAINERS, FACILITATORS AND PARTICIPANTS}

Tostan has provided training for:

-32 trainers for the adult, adolescent and girl child basic education programs;

-152 facilitators responsible for facilitating class sessions with village participants and working with the Village Management Committee;

-286 leaders of 143 Village Management Committees composed of clected members who manage activities at the educational centers in collaboration with Tostan. The Village Management Committees allow the participants to assist in the direction and management of Tostan activities which benefit them directly. These committees reinforce the application of leadership and management skills learned throughout the core modules of training;

$-18,834$ adult villagers and 2,532 adolescents and young women throughout nine regions of Senegal.

Tostan has also provided training for trainers, facilitators and village participants for 28 national and international Non-Governmental Organizations (NGOs), village associations or women's groups in nine regions of Senegal and in other African countries reaching approximately 10,000 other village participants.

\section{- OTHER ACHIEVEMENTS}

-Tostan has constructed 153 latrines and more than 4,000 energy conserving cooking stoves in collaboration with participants in villages participating in the education program throughout Senegal.

-Tostan has initiated credit programs and several types of micro-cnterprises for villages having benefited from the Tostan basic education program, training village management committees to be responsible for their implementation.

-In collaboration with a private Senegalese radio station, Sud-FM, Tostan produces a weekly program on children's rights to contribute to civic education for adolescents and girls.

The vast experience that Tostan has acquired over the years in materials development, training, management of learning centers in the field, social mobilization and evaluation of programs enables our organization to respond efficiently and effectively to the needs of the Senegalese population. Over the past three years, Tostan has also gained expertise in helping participants implement projects and obtain credit for small income-generating activities which reinforce skills acquired during the education program.

\section{- IMPACT OF THE PROGRAM}

The results of the Tostan Basic Education Program in the participating villages has been positive. Evaluations show that in the various domains covered by the program, important improvements have been noted: 


\section{Problem-Solving - Module 1}

- Participants have used the problem-solving process to repair pumps, wells, millet machines, build literacy centers, do woodlots, solve problems of water, etc.

- Participants have begun garden projects, improving the nutrition of their children and the family economy

- Participants have constructed thousands of adapted wood stoves in all participating villages to reduce consumption of wood, thus protecting the environment

- Participants are creating new sessions (theaters, games, etc.) on subjects related to their needs and problems

\section{Hygiene - Module 2}

- Participants know about "germs" and wash food and hands before cooking and eating

- Participants systematically use soap and have begun soap-making projects in many villages to guarantee the availability of soap

- Participants regularly organize village clean-ups, often on a weekly basis / fines are imposed for offenders

- Participants keep their children cleaner

- Participants are constructing and using latrines

- Participants filter their water or use bleach to sterilize water

\section{Diarrhea and Vaccination - Module 3}

- Fewer cases of diarrhea are noted due to improved hygiene in homes and villages (committees formed to continually monitor this in almost all villages)

- Almost no cases of dehydration due to diarrhea have been noted in villages

- Women know and understand the vaccination calendar

- There exists a vaccination "reflex" in villages where Tostan had centers according to local health agents, women regularly have their children vaccinated

\section{Management Skills - Module 4}

- Women are able to manage their own projects

- Good record-keeping skills are observed for village projects

- Management committees assure transparency in projects

- Committees are well organized and meet regularly

- Participants are maintaining family budgets

\section{Leadership - Module 5}

- Participants are choosing leaders based on competency and not on sex, age and social status

- Relationships between local authorities and villagers has changed Village women are no longer afraid to meet and discuss with administrators

- Many women have become leaders in these villages

- Participants are demanding accountability from their leaders

- Participants no longer hesitate in denouncing corrupt practices

- Women participate more in local politics 
- Participants are used as mediators by the community

- Women regularly speak out in meetings

- Women participate more in the decision-making process

- Participants organize educational sessions in neighborhoods and other villages

- Women know where to go to find information, know how to use resources

\section{Feasibility Study - Module 6}

- Women do feasibility studies and have started their own projects

- Women have received and managed credit for millet machines, small businesses and other income-generation activities

- Participants organize visits to other villages for an exchange of experiences

The achievements of the Tostan basic education program have contributed in Senegal to:

- the lowering of infant mortality rates through education on hygienc, vaccination, Oral Rehydration Therapy (ORT), breast feeding, child care, malaria prevention and treatment, and the harmful effects of Female Genital Cutting;

- the lowering of maternal mortality rates through education on women's health care, hygiene, family planning, pregnancy, childbirth and the harmful effects of FGC;

- the empowerment of women and an increase in democracy through education on human rights, leadership, and democracy which builds confidence in women and provides skills in problem-solving, negotiation, strategic planning, social transformation and conflict resolution;

- the reduction of poverty through employment and entrepreneurship as a result of Tostan's teaching of literacy and numeracy skills as well as the construction of local capacities through training for effective management skills, feasibility studies, creating and implementing micro-enterprises, and obtaining credit. 


\section{THE TOSTAN CONTINUED EDUCATION PROGRAM: MODULES 7 AND 8}

\section{INTRODUCTION TO MODULES 7 AND 8}

During the study of Modules 7 and 8, the participants of the Tostan program made the important decision to end FGC in their villages. It is therefore important to go into greater detail and explain the process involved in developing these modules as well as the methodology and content of the sessions. It is now clear to us that the human rights education is a critical component of both modules and is essential for self-actuation in many domains of life, not only for ending FGC.

\section{BACKGROUND INFORMATION ON MODULES 7 AND 8}

In 1994, Tostan proposed a project to the American Jewish World Service (AJWS) to contribute to the reduction of illness and death among Senegalese women and children. The project was to develop and implement a continued learning program related to women's health and early childhood development. This program was intended to reach thousands of literate and illiterate Senegalese villagers, mainly women.

The goal of the program was to improve the physical and mental well-being of thousands of women and children throughout Senegal. The objectives were :

- To develop relevant, participatory educational materials for Senegalese villagers related to women's health, child survival and carly childhood development;

- To test the educational materials in villages in the Central and Northern regions of Senegal ;

- To extend the program to other villages throughout Senegal;

- To enrich the Tostan non-formal education program by providing post education modules for Tostan villages and other Non-Governmental Organizations using the Tostan program. The process used to develop the modules included the following steps:

\section{Surveys in villages to determine subjects which interest future participants} in the educational modules.

Three Tostan women trainers participated in this activity, spending considerable time in 13 villages in the Kolda, Diourbel and Thiès regions of Senegal.

Comparison of subjects which interest future participants with priorities of the government at local and national levels - Choice of subjects

This step was necessary since many of the subjects that women were interested in were not nccessarily vicwed as priorities by the Senegalese government. By studying health statistics and discussing the issues with national and local health workers, the team members had a better idea of what should be included in the two modules. Many 
issues such as information on menstrual periods, menopause, FGC, abortion, relations with local health workers, and violence towards women were not high priorities for the government. Most women, however, expressed great interest in these subjects and therefore they were retained for study in Modules 7 and 8 . On the other hand, one of the government's and the women's major concerns was maternal mortality; thus the Tostan team decided to devote several sessions of the module to pregnancy and childbirth.

\section{Return to villages for further participatory research}

Once the subjects were chosen, team members returned to the villages to do further investigations with the women on the various subjects. Tostan was particularly interested in local language vocabulary used to describe the health problems, traditional practices, cultural concerns and taboos related to the subject. They solicited suggestions for solutions to problems which could be integrated in the module.

\section{Study of existing materials and other educational efforts related to the subjects chosen}

The team then identified educational materials which have already been developed in Senegal related to the subjects chosen. This was a difficult, time-consuming process since most materials were only available in Dakar. Some agencies cited publications, but were unable to locate materials. In fact, few materials were found, particularly in national languages.

\section{Writing up the information on each subject}

This step was essential for determining session objectives and establishing priorities. It also served to summarize information collected from the women in the field. These summary sheets on subjects were constantly referred to in writing up each session.

\section{Writing up the modules}

Each module includes 24 sessions and each session was carefully planned to convey simple technical information through stories, theaters, games, poems, songs or intervicws. The modules included social mobilization strategies and ideas for practical action inspired by the participatory research. Emphasis was put on critical thinking and allowing women time to exchange ideas freely in a non-judgmental atmosphere of confidence and trust.

\section{Feedback from others in the health field and in women's development}

Several people read the modules in French before they were translated into Wolof and Pulaar. Tostan worked with the health officials directly concerned (Director of Maternal Health, Director of Hygiene and Nutrition, Dr. Gueye) as well as ressource people at UNICEF and other agencies who read Modules 7 and 8 and gave important feedback on their reliability.

The following is the schedule of themes for Module 7 : 
WEEK 1

\begin{tabular}{|c|c|}
\hline Session 1 & $\begin{array}{l}\text {-Getting to know one another } \\
\text {-Fears and hopes for Module } 7 \\
\text {-The objectives of Module } 7\end{array}$ \\
\hline$\underline{\text { Session } 2}$ & $\begin{array}{l}\text {-A definition of health } \\
\text {-The situation of women in the village } \\
\text {-Favorable and non-favorable factors related to } \\
\text { health in the village }\end{array}$ \\
\hline Session 3 & $\begin{array}{l}\text {-Women's situation in Senegal, Africa and the world } \\
\text {-Using statistics to understand priorities }\end{array}$ \\
\hline & WEEK 2 \\
\hline$\underline{\text { Session } 4}$ & $\begin{array}{l}\text {-Women's rights ( } 2 \text { sessions) } \\
\text {-Human rights for health and health care }\end{array}$ \\
\hline Session 5 & -The importance of prevention in health \\
\hline$\underline{\text { Session } 6}$ & $\begin{array}{l}\text {-The development of the body: Puberty and } \\
\text { menstruation }\end{array}$ \\
\hline & WEEK 3 \\
\hline Session 7 & -Women's sexuality \\
\hline Session 8 & -Writing poetry on health \\
\hline Session 9 & -Pregnancy - 1 \\
\hline
\end{tabular}

\section{WEEK 4}

\begin{tabular}{|l|l|}
\hline$\underline{\text { Session 10 }}$ & -Pregnancy - 2 \\
\hline$\underline{\text { Session } 11}$ & -Childbirth \\
\hline$\underline{\text { Session } 12}$ & -Abortion \\
\hline
\end{tabular}

WEEK 5

\begin{tabular}{|l|l|}
\hline$\underline{\text { Session 13 }}$ & -Menopause \\
\hline$\underline{\text { Session.14 }}$ & -Female Genital Cutting (2 sessions) \\
\hline$\underline{\text { Session 15 }}$ & -Violence against women \\
\hline
\end{tabular}

WEEK 6

\begin{tabular}{|l|l|}
\hline$\underline{\text { Session 16 }}$ & -Review of previous sessions \\
\hline$\underline{\text { Session 17 }}$ & -Sexually transmitted diseases \\
\hline$\underline{\text { Session 18 }}$ & -HIV and AIDS \\
\hline
\end{tabular}

WEEK 7

\begin{tabular}{|l|l|}
\hline$\underline{\text { Session 19 }}$ & -Relations with local health workers \\
\hline$\underline{\text { Session 20 }}$ & $\begin{array}{l}\text {-The problem solving process applied to village } \\
\text { health problems }\end{array}$ \\
\hline$\underline{\text { Session 21 }}$ & $\begin{array}{l}\text {-Establishment of a village health association } \\
\text { (Goals, objectives, activities) }\end{array}$ \\
\hline
\end{tabular}


WEEK 8

\begin{tabular}{|l|l|}
\hline Session 22 & $\begin{array}{l}\text {-Establishment of a village health association } \\
\text { (Organization and functions) }\end{array}$ \\
\hline Session 23 & -Revision of Module 7 \\
\hline Session 24 & -Final evaluation of Module 7 \\
\hline
\end{tabular}

\section{SPECIFIC INFORMATION RELATING TO FEMALE GENITAL CUTTING IN MODULE 7}

The Tostan team of women doing participatory research for Module 7 , Women's Health, discussed at length the subject of Female Genital Cutting to decide whether it should be included in the module. The hesitation was due to a cultural consideration: women had been reluctant to discuss FGC during the participatory research phase. Certain women expressed some hostility at the mere mention of the issue. The team decided nonetheless to tell, in Session 14, the story of a girl who goes through the rite, is cut, then hemorrhages and dies. This session was experimented with women of the Pulaar and Bambara ethnic groups. It is important to note that the session follows many others in which participants learn about the development of the body and also discuss sexuality as a natural part of women's development. After 13 villages had decided to end FGC, a second session was added for new participants both in Module 7 and Module 8 and included the villagers' declaration.

\section{SESSION 14}

FEMAIE GENITAI , CUTTING

\section{OBJECTIVES}

At the end of the session, the participants :

- will be able to discuss the health risks related to this practice ;

- will have adapted a new attitude pertaining to FGC.

\section{MATERIAL}

- The story of Poolel

- Drawings for Session 14

- The WHO resolution on FGC

\section{PREPARATION}

- Prepare a theater presentation with volunteers from the class using the story in this session and adapting it to the realities of the village women. Tell the volunteers to make the theater as vivid as possible by using real circumcision songs and crying loudly as one does when a death is announced in the village. 


\section{PROCEDURE}

$\underline{R E V I E W}$

- Ask the women to read the poem they wrote on menopause during the last class meeting.

\section{PRESENTATION OF THE THEATER}

- Ask the volunteers to present their theater adapted from the following story. The theater will be adapted to local realities and should be rehearsed several times before it is presented :

Poolel was a young girl eight years old. One day, her father's sister came to get her, accompanied by a traditional circumciser. Poolel, along with her other girl friends of the same age, was to undergo the ancient rite of circumcision practiced by her ethnic group. This operation would help her to become "a real woman" and give her dignity and value in her society.

Unfortunately, something terrible happened! Poolel bled profusely and the family was quite worried. They went to visit the nurse in their village.

The nurse was angry because the family had circumcised Poolel and tried to get the bleeding to stop. Poolel continued to bleed and was suffering terribly. Finally, they evacuated her to the regional hospital where the doctors tried to save her life. It was too late. Poolel died the next day.

\section{DISCUSSION OF THE THEATER}

- Ask the participants to first summarize the theater they just witnessed.

- Lead a discussion using the following questions as a guide :

- What are your feelings about this theater?

- Do you know women who have been circumcised? If you do, what do they say about this practice?

- Why do you think girls are cut? Do you think it is a necessary practice? Why or why not?

- Would you have your own daughter cut? Why or why not?

- What health dangers are related to FGC? Have you ever heard of women who had these problems? (Use the drawings for Session 14 and explain the health problems linked to FGC: bleeding and hemorrhaging, infection, pain, difficulty urinating, stress or shock, complications at childbirth, etc.)

- What taboos are related to the woman who is not cut? Do you believe these taboos?

- What does Islam say about FGC? Is it an obligation prescribed by the Koran? (Nowhere in the Koran does it require a woman to be cut.) 
- Read the following resolution adopted by the World Health Organization: "Sexual mutilation is an act of violence towards the young girl which will effect her life as an adult."

- Ask the following questions :

- What do you think of this resolution?

- We all know that mothers practice this tradition out of love for their daughters, so that they will be respected members of their society. Why do you think the World Health Organization would make such a statement?

- Do you think that FGC can have a negative effect on the life of women? Why or why not?

- Do you think FGC violates any of the articles of the Human Rights Convention we discussed at the beginning of this module?

- Spend sufficient time discussing these questions. Remember not to be judgmental, particularly if you are working with an ethnic group which practices FGC. Ask the women if they would like to organize a debate on the subject with other women in the village.

- Ask the participants if they would like to discuss this issue with local health agents, religious and traditional leaders.

\section{RESULTS OF TRAINING FOR MODULES 7 AND 8}

Altogether, approximately 8,000 women participated in training for Modules 7 and 8 in 4 regions of Senegal: Thiès, Diourbel, Kolda and St. Louis. Multiple evaluations show that the women know and understand the information presented. Most importantly, they use the information to bring about change in the villages.

The comments during evaluations reflect the following attitude and behavioral changes:

- Women have an increased awareness of the importance of their own and their children's health

- Women can cite and can give examples of use of their rights (right to health, expression, choice of husband, family planning, protection from all forms of violence, etc.)

- Parents have a new awareness and respect for the rights of children (right to education, to not be exploited, to live with their two parents, to health, to play, etc.)

- Women know symptoms and treatments for many illnesses, when to seek care and how to prevent illness

- Women are sharing their new information with other villagers and are holding discussions in neighborhoods and other villages

- Women breast-feed exclusively for the first four months

- Women have started to use family planning methods

- Women explain menstruation and sexuality to their children for the first time 
- Pregnant women seek prenatal care and say they prepare for the birth of their children for the first time (materially and financially)

- Couples discuss issues more openly and honestly for the first time

- Men no longer make all the decisions for the couple

- Women are discussing sexuality with their husbands for the first time and say the session on sexuality improved their relationship with their husbands

- Women who felt their husbands were discriminating against them because they are past menopause consulted with village leaders and together found solutions to these problems

- Women are questioning and often stopping traditional practices which harm their children, such as FGC, early marriages, etc.

- Women know about good nutrition and have changed dietary practices to improve the health of their children

- Villagers have established fines for people who give their children too much work

- Villagers have led campaigns to bring young girls who have been sent to towns as maids back to the family

- Participants assure regular vaccination for the children in the villages

- New communication has been established between mothers and their children, particularly relating to formerly taboo subjects such as sexuality

- Participants now use iodized salt (particularly in the Kolda region Medina Cherif)

- Villagers have started health huts, health tables and other health activities such as collecting data, analysis of data, etc.

- Participants have begun "solidarity funds" to help villagers when in need

- Women are writing poems and texts, writing openly of their suffering and experiences for the first time

There was unanimous agreement that learning about human rights and discussing ways to attain respect of these rights in everyday life was an empowering experience for the women.

Tostan received many village delegations expressing gratitude for the continued education Modules 7 and 8. One village delegation stated: "You just can not imagine the impact that these modules have made in the village - you don't realize how important it is for us and the change it has brought about!" (Kulug) We were told that information sharing on Modules 7 and 8 took place while the women waited in line for water at the well, as they did daily chores or at the market. Many villages held festive ceremonies at the end of the module and gave out diplomas, inviting neighborhood villagers and local authorities. The use of poetry was a powerful tool in Modules 7 and 8. The women often wrote collective poetry to express their feelings on many subjects from menopause to sexuality to AIDS. The poems were then used in public ceremonies often with traditional music or singing to accompany them. One village participant from Ngaparu wrote the following poem: 


\section{WHO IS MODULE 7?}

Ah! Module 7!

You came to Ngaparu and chased away illness from our families

Come Module 7 !

Help our Senegalese women know their rights

Especially their right to health.

Help them to learn about their bodies.

You, women of Ngaparou

Share your knowledge with your daughters

Especially at puberty.

Speak to them about menstruation, about sexuality

Don't be ashamed any longer!

Women of Senegal, answer Module 7's call

And she will inform you about pregnancy,

Helping you to learn

How to have a successful pregnancy.

Answer Module 7!

She will tell you about childbirth

And the importance of planning your childbirth.

You will understand

That Female Genital Cutting is violence towards our daughters

So you will stop and ask our sisters and brothers

To abandon such harmful traditional practices!

You, married women, listen to the Module

And learn about STDs, and above all AIDs.

You, older woman of Senegal

Listen to Module 7....

She will tell you about the signs of menopause

So you will not be surprised, but rather prepared!

All of us must listen to Module 7 to know how to analyze

Our resources, their costs, and where we can find them.

You, Module 7

You have helped to create Associations in classes, in villages

So that we women may find solutions to our problems!

Problems of our daily lives, problems in our homes,

With our husbands, with our children

With our leaders and our neighbors.

Another poem written by the women in another class reinforces the importance of learning about women's rights. 


\section{WOMEN'S RIGHTS}

We, the women of this class

Have a new friend -

A wonderful friend

Who is righteous and just

And who now guides us

On the many paths of our lives.

"Who is this friend?" you ask.

The name of our friend

\section{Is Women's Rights}

And to think we knew nothing

About her before our class!

Nothing about these rights

That we want to tell you about now:

-All people are born equal

And have equal rights!

-The right to be protected from any form of discrimination

Especially WOMEN!

-The right to be involved in politics

-The right to work

-The right to be informed

-And the right to speak one's mind

-The right to choose one's religion

-The right to be protected from ALL forms of violence!

-The right to have a family and marry the person of one's choice

-The right to privacy

-The right to belong to organizations

-The right to education

-The right to land

-The right to HEALTH!

These rights

Have changed our lives

And our attitudes

In our homes, in our neighborhoods

And in our country.

Before we felt unsure and oppressed

We walked with our heads lowered!

But now our heads are held high -

We have confidence and are ready

To participate in all activities!

Everyone should understand that

Women's Rights are a Woman's Friend! 
So let's spread the news to all people

And especially all women

So knowledge will spread throughout the land

And ignorance and injustice be only remnants of the past.

Several examples of concrete actions taken after the village training indicate the success of the modules.

During the month of January, 1997 one of the trainers, Mamadou Nieng, reported that in a village near Thiès a man "beat up" his wife. The members of the women's health class immediately met to analyze the problem. They discussed the session on violence and women in Module 7, rehearsed the sketch once again, formed a delegation including the village chief and religious leaders and went to visit the man. In their sketch, they presented human rights and specifically the right to be protected from all forms of violence. The man apologized to the women and gave their organization 5,000 fcfa. He promised never to hit his wife again and claimed it was ignorance on his part and certain traditions and habits that have never before been questioned. He told the trainer that he was really sorry and that he had learned a lot that day from the women. He encouraged the trainer to continue extending the module to other villages, but for men also.

A woman from Malicounda Bambara told Melching in an interview: "Everyone thinks that ending FGC was the most significant aspect of our training from Modules 7 and 8, but there were many other important things we learned and then were able to put into practice. For example, I was married for four years and couldn't get pregnant. When I learned about Family Planning in Module 8 I was really amazed. I thought Family Planning was about stopping or limiting births and didn't know it could help you to HAVE children. I participated actively in the classes, asking many questions. Afterwards I went home and calculated. Then I went to see my husband who travels frequently and I told him I wanted him to be home at a certain period of time in the coming month. He looked at me as if I were crazy, but I begged him to do as I said without explaining why. He did as I asked and I indeed got pregnant for the first time. I was amazed. He was amazed. So then I counted out the number of days since conception and came up with an approximate date for the birth of my baby: December 24. Using the planning sessions for childbirth from Module 8, I started carefully putting aside the money, medicines and materials I would need by December. I asked my husband to plan to be home at that time. He said: 'Who do you think you are? God?' I said 'No, I have just studied and I have lots of new information that I didn't have before.' In early December, my friends started planning activities for the holidays, but I told them I would not be able to participate because I would be 'otherwise occupied'. They wondered how I knew this and I smiled mysteriously. I gave birth to my baby here on the morning of December 25. Everyone was surprised but I wasn't. The medicine I needed was there, as well as all the things I needed for giving birth and afterwards. I had money set aside in case there was an emergency so I felt reassured. My husband was there. And now look at how healthy my baby is." 
Modules 7 and 8 were two of the most popular modules that Tostan has developed to date. There are many elements which made these modules effective:

- the participatory research over a one year period leading to choice of subjects based on interest of participants

- the use of the women's own stories and experiences within the module

- the practice of having participants "adopt" a friend or relative and share the information of the sessions with them (called "ndey-dikke" in wolof)

- the reinforcement of positive cultural practices and values

- the emphasis placed on action and peaceful strategies for social change

- the selection of highly qualified, motivated and caring women facilitators

- the reinforcement of skills and information learned in Modules 1 through 6

- the inclusion of local health workers and traditional healers in the implementation of the program.

Finally, benefiting from elements critical to effective teaching for all our modules, Tostan has learned to write and organize sessions into a coherent program. Combining all these elements with a strong human rights component led to an historic event: the ending of Female Genital Cutting in 31 villages in Senegal. 


\section{PART TWO}

A description of what happened in ending FGC in 31 villages in Senegal

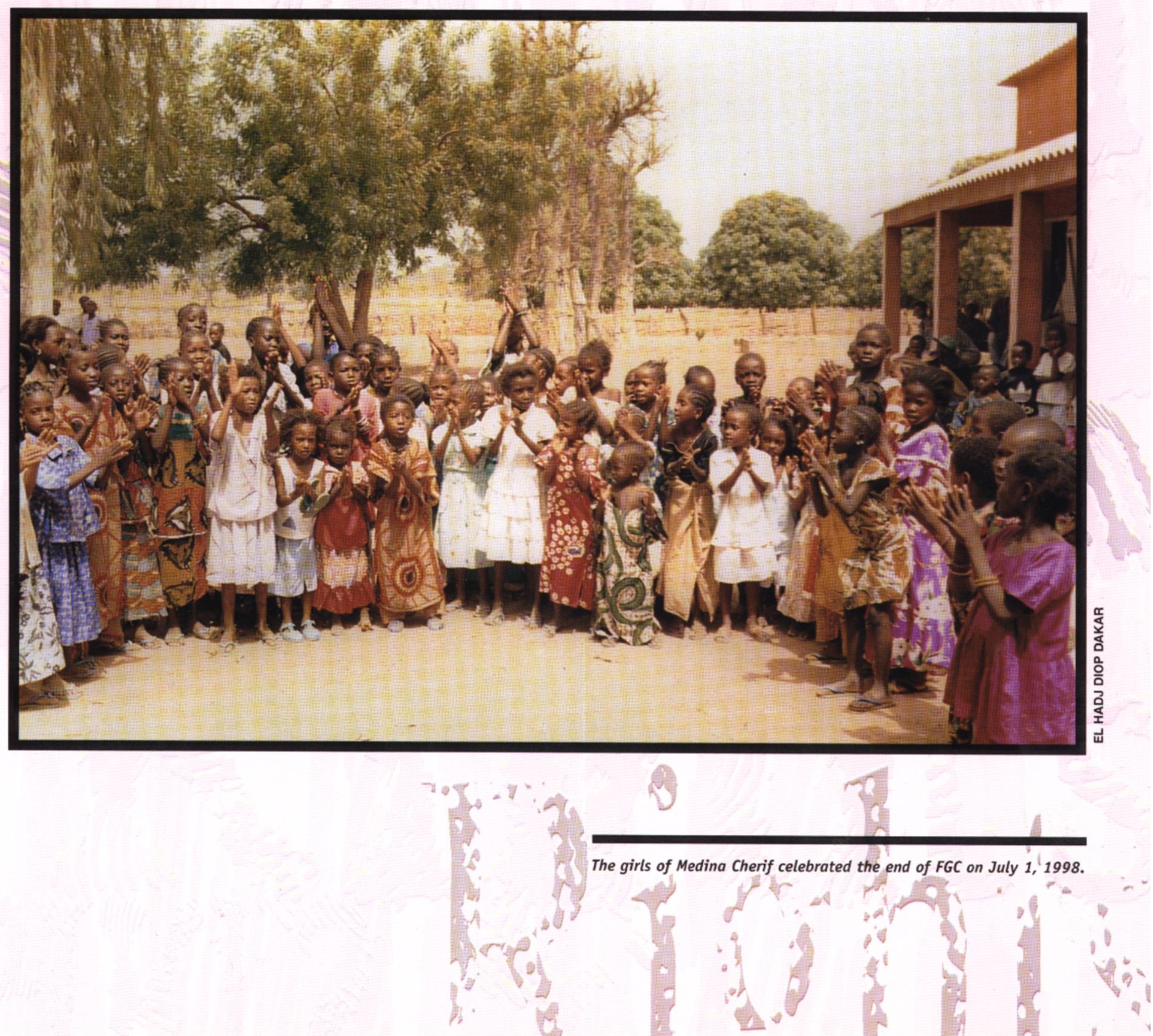




\section{A DESCRIPTION OF WHAT HAPPENED}

\section{MALICOUNDA BAMBARA: THE BEGINNING OF THE END}

Malicounda Bambara was one of the many villages participating in the Tostan basic education program, Modules 1 to 8, from 1995 through 1997 in the regions of Thiès and St. Louis. The women of Malicounda Bambara studied Session 14 of Module 7 on Female Genital Cutting in August of 1996.

According to the facilitator, Ndey Maguette Diop: "The women were hesitant to do a theater adapted from the story at first. We kept the same name as in the story - Poolel - which is a pulaar name and didn't directly implicate the Bambaras in this tragedy, which may have helped. The women did the story as theater, but refused to discuss it afterwards. I kept asking them the questions that accompany the session and no one would answer. The discussions in Sessions 1 through 13 were normally lively and animated. 'Why were they refusing to answer the questions?' I thought. 'Is it because I am Wolof and have not practiced FGC?' So I did the session again and again. Three times. The third time they finally started talking timidly then more and more women spoke up. They admitted that it was an ancient practice that they followed because it was a tradition and expected of them by the men and religious lcaders. Nonetheless, their human rights training helped them to understand that they have the right to the highest standard of health. They also have the right to express themselves and give their opinion. They hadn't known all this before and had never discussed it together. Finally, we ended up talking and talking about it together often. The women decided to talk to their "Ndey Dikke" (adopted sisters) and to their husbands about the dangerous health consequences. They also thought it important to first get the advice of the Imam and the village chief on the issue. They were surprised when they discovered that many fellow villagers supported an effort to end FGC. They then performed the theater in other neighborhoods of the village, and decided to get those women discussing the issue."

The women said they began talking in class and discussed the issue even more outside of class when they were alone. They said there were things the facilitator, Ndey Maguette, could never understand and that they needed to work out among themselves.

By June 1997, the women had convinced enough people in the village of the danger of FGC that there were no public circumcision ceremonies held that year during the rainy season. "By that time", states a class participant, "everyone was aware that there was a movement to end the practice in the village. If any woman did cut her daughter, she did it in secret for the first time, knowing she would be subject to public disapproval."

In June of 1997, the Tostan coordinator, Malick Gueye, called Tostan to break the news. "Did you know that the women of the class of Malicounda Bambara have stopped FGC in their village? They told me that it is one of the most important results of their basic education program and I thought you might want to know."

Bilal Ndiaye, the head of training at Tostan, and Molly Melching visited the 
class that same week and met with the President of the Women's Group - Maïmuna Traore, the village chief and the Imam. Melching and Ndiaye were hesitant to discuss FGC, knowing the sensitivity surrounding the subject, not realizing that the people had discussed it so much already that it was no longer a delicate subject for them. They immediately started discussions by clearly stating "We have decided to end the tradition' in our village." Here is Melching's report on the meeting:

\section{Malicounda Bambara \\ Region of Thies \\ Department of Mbour \\ Population approximately 3,000 \\ Situated 10 kilometers from Ngekhokh}

The women of Malicounda Bambara have made up their minds. They will no longer practice Female Genital Cutting (FGC) on the young girls of the village! There will no longer be annual ceremonies to mark the moment when "girls" become "real women" following the ancient traditions of their ethnic group. No longer will needles and razor blades be used to cut the girls. No longer the flow of blood. No longer suffering on the wedding night of their daughters and complications at childbirth. No longer will young girls die needlessly from infection or hemorrhaging caused by the female circumcision rite!

But how did a group of African women from an ethnic group which has known and practiced FCG for thousands of years have the courage to stand up and say "no more" to such a powerful and ingrained tradition? How did they convince the other members of their community, particularly the men and the older women who fight to preserve Bambara traditions? The women told me their story.

"We had been enrolled in classes in the Tostan/UNICEF/Government of Senegal Basic Education Program in national languages and we women of Malicounda Bambara had begun to change," explains Maïmuna Traoré, President of the Management Committee of the village class. "We started thinking and talking about things in class that we had never before discussed, things that had always been 'taboo', you might say. In Module 1, we worked on problem-solving and from then on tried to look at some of the problems we women have in our village and we thought of different solutions for these problems. In Module 2 we learned about germs and the spread of disease and that made us think a lot about some of our traditions that might be dangerous for our children." As Maïmuna talks, she cuts up a large bar of homemade soap produced by the women of the class. "Actually, the Tostan program gave us a certain amount of confidence that we never had before. Confidence that we could change things if we wanted to."

"That's true," says another participant, "the education sessions woke us up. We received information that we never had before and the new knowledge has given us a voice in our community. For the first time when we speak, everyone listens because what we say is based on objective facts."

Kerthio Diarra asks to speak: "We studied Human Rights in the Tostan Module 7 on Women's Health and particularly the right to health. We learned that this right implies the freedom of each woman to decide for herself what she does with her 
body. She also has the right to preserve her body as it is, without mutilation or changes. This was a revelation for us since it was in contradiction with one of our oldest traditions: the circumcision of all female children. In fact, in our traditions, it is unthinkable not to circumcise girls - why she would be the laughing stock of the community and could never find a husband! It was so important that we were told that an uncircumcised woman was "dirty" and not fit to prepare and serve food to those who study the Koran! Yet, we have always been uneasy about the disadvantages linked to circumcision. Many of us suffered greatly during sexual relations with our husbands and during childbirth. Many got infections or hemorrhaged after the operation."

After learning about the negative health consequences of FGC, the women of the class went to the Imam of the village and asked his opinion on the subject for the first time. Serigne Amadou Touré told them that not only did the Koran not oblige them to practice this rite, but that he himself was against it. He explained that his own first daughter underwent the operation without his knowledge. When he found out, he told his wife not to let it happen again. His other daughters were not circumcised. This made a great impression on the women of the class who had always believed that FGC was indeed recommended by the Muslim religion. They merely assumed that all the Imam's daughters would be circumcised. "This information gave us new and powerful arguments for convincing our husbands and friends to end FGC and we immediately added this information to the play we had created against the practice." says another participant.

"You know, we're now aware that we have the right to a normal and dignified sexual life! Our daughters also. So we asked ourselves lots of questions," says another participant, "For example: Is FCG an act of violence against our own daughters?"

Maïmuna explains that the women first made the decision to stop FCG as a class. "Then we discussed that decision with the traditional and religious leaders of the village, as indicated in the modules of our education program. We learned that the Muslim religion doesn't require female circumcision, only male circumcision. We talked with our husbands and they understood our concerns. Encouraged by their support, we did a theater on Human Rights that included messages on the dangers of FGC and we went to all the neighborhoods in the village - Binabougou, Julacounda and Kahaydacounda. We invited our village midwife to these sessions and she was also convincing since she had seen many cases of suffering among women and children caused by this practice. After only several months, the women of Malicounda Bambara had agrecd to stop the ceremonies for this year and indecd to forever stop a practice that is no longer justifiable in our community because of the health dangers it poses for our daughters."

An elder woman who had been listening attentively to the younger women talking suddenly spoke out: "We old women were the ones who insisted that all the girls of the community be circumcised! Even when the parents were against it, we'd go take the child and do it when they weren't around. But I'm in this class and I learned about human rights. Did you know that every man and woman have the right to marry and live their lives according to their own beliefs? When I found that out, I realized I could no longer impose my will on my children and grandchildren."

The village chief who was present during the whole discussion gave his opinion for the first time: "I'm not a member of the class, but I support the women's decision. 
Life is constantly evolving. We have even heard that in Mali, where we come from, that people are discussing and questioning FCG. But changes in traditions take a long time. It's hard to put an end to an ancestral practice which has lasted for thousands of years."

Kerthio responds immediately: "That may be so but we women have given this a lot of thought over the past year and we've made our decision! We're going to stop FCG in Malicounda! Now those who continue to do it will be the ones who are laughed at. Those who feel they must continue will have to hide, as people do when they are ashamed."

Maimouna shows us the pieces of soap ready for sale in the market that she has just finished cutting:

"This decision we made brought us other advantages too. We became aware that we could make a difference in the world. Maybe that's why we chose many of the education sessions in the modules we have studied and we go from neighborhood to neighborhood to facilitate discussions with the other members of our community: men, women and young people.

"We also did a feasibility study which we learned in Module 6 and started a small income-generating project to produce and sell soap which, even though a small effort, will help to improve conditions of hygiene, health and living conditions of participants. We are managing the project ourselves and our now planning other, more ambitious activities for next year."

\section{THE IMPACT OF THE MALICOUNDA BAMBARA DECISION}

Molly Melching sent this interview with the women to the UNICEF representative in Dakar, Mr. Samir Sobhy, and they discussed the Malicounda decision. Mr. Sobhy felt it was important that the women share their ideas with as many Senegalese as possible for several reasons:

-the women had made this decision of their own free will and not because Tostan had tried to impose it on the village;

-the decision resulted after the women had already spent two years in the basic education program; they were accustomed to working together, trusted the program and one another and would be able to defend their decision with information from their modules on hygiene, health, problem-solving, leadership and human rights conventions;

-there were no circumcision rites held publicly that year, indicating they had really put into practice their decision and not just expressed the wish to do so.

When Mr. Sobhy said he wanted to send 20 Senegalese journalists from the radio, newspapers, magazines and television, Melching was quite hesitant. 'I'm worried about the women!" she told him.

"Molly, if these women were strong enough to make this incredible decision on their own, they are strong enough to defend their position before 20 journalists." $\mathrm{Mr}$. Sobhy replied.

He was right. The women did not hesitate when Melching told them that Tostan and UNICEF wanted to bring 20 journalists to the village. "Yes!" they all 
answered. "We have good news to share with everyone. Why not discuss it? This will be an opportunity for us to explain why we made the decision."

As they prepared for this event, they asked for even more information on human rights articles so as to better defend their position. They rchcarsed their play and invited the religious leaders and village chief to come to the event.

The visit of the journalists went well. High placed representatives from the Ministry of Health and the Ministry of Women, Children and the Family congratulated the women and told them of the strong support they had from these ministries in the government. Many articles appeared in several national newspapers. Radio interviews in French and in national languages were broadcast during the following two weeks while the television news spot showed the women, their play and a religious leader's interview. The coverage was extremely positive and portrayed the class members as courageous, intelligent women who had made a decision based on their knowledge of human rights, the negative health consequences involved, and a desire to end a practice that no longer had a meaning within their community.

The reaction to their decision was both positive and negative. Many people applauded their action. Others felt they needed time to assimilate the decision. Men and women from the same ethnic group in a neighboring town were angry and felt betrayed. New articles appeared in newspapers with various reactions from Senegalese, sometimes criticizing the women's decision. Some people believed it was Western influence on the women, because the director of Tostan is American.

One newspaper article in "Le Soleil" was accompanicd by a cartoon of women burning down the "circumcision hut" and a young girl from behind saying "Anitche" meaning "Thank you!" in Bambara.

The women from Malicounda were upset by this cartoon. "They are portraying us as revolutionaries! We are not revolutionaries. We are making peaceful change in an effort to promote women's health. We are NOT attacking our traditions. We are attacking one practice which has dangerous health consequences for our daughters," Ndey Mareem Traoré lamented.

Meanwhile, the men of Malicounda began to complain. "When we agreed to the women's decision, we never dreamed that they would be discussing the issue out in the open, so publicly," one man told Tostan. "If they had just made the decision and quietly enforced it we would have no problem. But they are discussing secret things related to our culture that should not be talked about in public."

Tostan held meetings with the women after these articles appeared. The Malicounda women all had long faces and seemed depressed. The effervescence and joy-of the meeting with the journalists was gone and they were visibly worried by the reactions they had stirred up around the country, in their neighboring town of Mbour and in their own village.

"You know this may get worse," Melching told them. "You can never control what journalists write in the newspaper or show on television. Things may be distorted even more. It is not too late. If you want to stop discussing this with the media, we can do that. We can stop bringing people here to speak with you so that others will no longer write about Malicounda."

After several moments of heavy silence, Tene Cissoko, a 34 year old mother of 3 , stood up. "No. We will not stop speaking of this to others. We made this decision 
and believe in what we did. We must therefore have the courage to continue to explain why we ended 'the tradition' here. We are Amazons. We will continue the struggle to help our sisters and daughters."

A week later, the women learned that the villagers of Keur Simbara were preparing the circumcision rites for their daughters. "Can we go and talk to them?" asked Ndey Mareem Traoré. The women went to the Bambara village of Keur Simbara on a rainy August afternoon and were met by the populations with quiet reserve. The Malicounda women did their play on FGC and there was much discussion following the presentation, particularly relating to health issues and human rights.

For the most part, however, the women from Keur Simbara defended the practice as being an ancient tradition that is too difficult to stop from one day to the next. Maïmuna Traoré, the President of the women's group in Malicounda, ended the encounter by saying: "Take your time and reflect upon this as we did. At any rate, we are Bambara women just like you and we have made up our minds and are convinced of what we're doing."

About threc wecks after this event, the Imam and former Tostan participant, Demba Diawara from Keur Simbara, informed Melching that one of the problems with that meeting was the presence of neighboring Wolof villagers who do not practice FGC. He explained that for the men and women to criticize FGC in front of these other villagers would have been a loss of honor for them. He felt a better way to approach the issue might be to involve the entire "clan" in discussing the issue, together and free from any outside pressure or judgment. "Only when all members of the extended family agree will we assure that uncircumcised girls will be free from prejudice and able to find men to marry," Demba explained.

In September 1997, a journalist from Le Monde, Roland-Pierre Paringaux, spent a week at Tostan to report on the Malicounda Bambara decision. He wrote a one page article on the "Malicounda Pledge" which appeared on October 14, 1997. In this article, another issue was brought up that led to a new debate and more trouble for the women: the type of cutting that was practiced in Malicounda Bambara. Indeed, the women had explained in several open meetings that the Bambara tradition is to cut the clitoris and part of the labia and then to seal by letting the blood dry as in a wound, creating a type of infibulation, but without sewing as is done in countries such as Somalia, Djibouti and the Sudan. This, it seems, is a practice found not only among the Bambara in Senegal, Mali and the Gambia, but also among the Toucouleur in the St. Louis region of Senegal, particularly among the "Tooroodo" group of "noble warriors", the highest status among the Toucouleurs. It is a type of cutting that is not often described in books on FGC which have appeared over the years.

Mr. Paringaux wrote in his article that the women of Malicounda Bambara practiced infibulation which enraged the men of the village. At a meeting with the women after the article appeared on October 12, only about 25 women from the class came to the meeting. There was tenseness in the air. "Where are the others?" Melching asked. The response: "Oh, there's a death in the village." This became the standard reply from the women as fewer and fewer women showed up for the meetings. In fact, pressure from the men had caused some women to refrain from further participation in the activities at this time. Also, no men came to the meeting. 
Melching later learned that the same day of her visit, the men had called a "General Village Assembly" to discuss the articles which had appeared in the press. The men were most disturbed by the article in Le Monde stating that the women practice infibulation in Malicounda Bambara. Tene Cissoko described that meeting in an interview in October, 1998 :

"That day the men called us to a meeting. Many adults were there, especially the men. In essence, they told us that we needed to stop talking about the decision we had made. They said they didn't agree with us on this aspect. The press was making statements that should not be discussed publicly and they had had enough.

"I asked to speak and said that although we recognized that they had the right to express their ideas, we also know our rights and know that we women have the right to express our ideas too. 'This is good news, not bad news,' I told them. 'We should be helping others by sharing our decision. We believe in what we did.'

"One man said: 'We will denounce you to the world'

"I said 'I know how to read and write. I will denounce you too!'

"This seemed to stop them. After that, they no longer said anything to us, but some of the women were afraid to come to our meetings when visitors arrived. A group of us decided it didn't matter, that we would just continue even if there were only 15 of us. We had the support of the President of the Women's group - Maïmuna Traoré, which was very important to us."

\section{NGEURIGNE BAMBARA FOLLOWS SUIT}

During his visit in September 1997, Roland Paringaux also met with the people of Nguerigne Bambara located about 15 miles from Malicounda. At a meeting with many villagers, including the village Imam and leaders, Paringaux was told that the different ethnic groups practicing FGC were still doing so in that village. One Serer woman who had married a Bambara man had undergone the operation herself so as to no longer be scorned by the other women of the family into which she had married.

The President of the women's group of Nguerigne, Ourèye Sall, daughter of a traditional cutter, explained openly for the first time that day that her own daughter had almost died after the operation. "I was so frightened" she explained. "I told my mother that she must stay to help me, but she said she had to go because she couldn't travel on the next day - the spirits were unfavorable for such a journey. So she just left me alone with my bleeding daughter. I tried to use traditional healing to get the bleeding to stop - but nothing worked. Finally I took my daughter to Mbour to the dispensary. Everyone was mad at me there because they knew my daughter had done the 'tradition'. I felt ashamed and started questioning whether I would continue the practice and become a cutter as my mother had wanted me to do. I thought, 'She's supposed to be the expert and she was unable to help me. What happens if I have the same experience? I don't want to be the cause of someone else's suffering.' Years later my daughter got married and had real problems during childbirth." At that moment, Ourèye Sall, turned to the Imam, Serigne Amadou Lamine Diagne, and asked cautiously: "Since this is the first time we have openly talked about this tradition in public and because the Imam is here with us, I would like to ask a question that has 
worried me for many years. Is it true that a woman who is not circumcised is really dirty and impure as we are told? Is it true that a non-circumcised woman cannot serve water or food to others, especially men?"

The Imam turned to Ourèye Sall and said "If you leave your home to walk down the road and find that your children are following you despite telling them to stay put, you might then warn them - 'There is a mean old hyena on this road! Go back!' But does that mean it's true? Is there really a hyena on the road? That is the answer to your question!"

This demystification of a common myth about uncircumcised women by the Imam himself made a great impact in Nguerigne Bambara. Nonetheless, the women were in the process of studying Modulc 7 on women's health at that time and explained that they needed further information on Female Genital Cutting and further discussion among members of the class, as well as consultation with their husbands and village leaders before making this important decision.

On November 6, Tostan visited Nguerigne Bambara with a journalist and a photographer from "Point de Vue", a French magazine. The journalists asked the women questions about FGC and Ourèye Sall told them that after having discussed the matter thoroughly in their class, then with the men and women of their village, and in an effort to support the women of Malicounda Bambara, they were now ready to declare an end to FGC as a community. She said that she would never cut another girl because she had learned that so many health problems were linked to FGC. The journalists were surprised and thrilled as there was no previous indication that the women were going to make this unusual announcement before the trip out to visit them. The journalists then decided to make this the major feature of their article with only a brief reference to Malicounda.

\section{PRESIDENT DIOUF PUBLICLY CONGRATULATES THE VILLAGE OF MALICOUNDA BAMBARA}

The President of Senegal, Abdou Diouf, gave tremendous support to the women of Malicounda Bambara in his speech to the 33rd Congress of the International Federation of Human Rights in Dakar on November 20, 1997 when he stated:

"Whoever speaks of Human Rights must necessarily include Women's Rights. I am convinced that in this area, we can equally make progress. The Minister of Women, Children and the Family has developed a Plan of Action that we must enact with much willingness. A group of women legislators has also proposed the need to modify our laws to reinforce equality between the sexes in the areas of tax law, social protection, labor laws and the Family Code.

"Lastly, we must vigorously fight against Female Genital Cutting. A law is no doubt necessary in order to demonstrate the commitment of public powers concerning this issue. But above all, the Government and Non-Governmental Organizations must work together to convince the populations that this practice constitutes a real danger to women's health. FGC frequently has led to hemorrhaging, infections and even maternal deaths. Today, this traditional practice can no longer be justified. 
"In relation to this issue, the example of MALICOUNDA deserves to be cited. In this Senegalese village, the women became aware of the dangers of this practice and engaged in dialogue with their husbands, the Imam and the Village Chief. Through a collcctive decision, the community decided to never again practice FGC.

"I today make a solemn appeal for the Malicounda experience to be followed and to spread throughout Senegal. I call for the organization of debates on FGC in every village, and ask everyone to become aware that the time has come to change this ancient practice."

The President also decided that a law against Female Genital Cutting was necessary and began the proceedings on February 3, 1998. Once again, he made reference to the women of Malicounda and the positive manner in which they brought about social transformation through education and dialogue.

\section{THE DIABOUGOU DECLARATION : ENLARGING THE PUBLIC PLEDGES}

Demba Diawara, the Imam from Kër Simbara, did not wait for the President's appeai. He was already visiting other Bambara villages near Joal with his nephew Cheikh Traoré to discuss their views on ending FGC. They went from village to village over a three month period from November 1997 to January 1998, convinced that their own village could not end FGC if they did not do it as at the same time as others in their family. Demba explained over and over: "Keur Simbara, dafa tuuti waaye dafa mag." (Keur Simbara is a small village but it is a very large village.) meaning that it was perhaps time to end FGC, but they needed the consent and commitment of the whole, extended family in ten other villages to make this decision since their children intermarry with those children.

The two Inen came by the Tostan office once in December and talked for nearly 3 hours. "I had no idea, no idea!" said Demba Diawara shaking his head. "I have heard unbelievable stories in the ten villages we are visiting - of girls suffering and women's pain during sexual relations and childbirth. The women never talked about this, never showed pain, never told us about the problems before in Keur Simbara most didn't even realize that this pain was linked to the practice of genital cutting. They thought all women have the same pain. If we had known before what we now have discovered during these public village meetings, we would have insisted that the women end FGC many years ago."

Demba also explained the strategy they were using, giving the example of the village of Samba Dia. "When we arrived in Samba Dia, I went to my cousin's house and discussed the issue first with him. He took me immediately to the house of the village chief who told me that he agreed with our efforts to end FGC; however, he preferred that we first discuss the issue with the local health agent and mid-wife. Together, we consulted them about this issue and they told us of the negative health effects they had observed in the village due to genital cutting. The village chief was convinced then that the whole village should attend the meeting and discuss the topic together. During that meeting, several people told stories of problems they had experienced personally related to FGC. Even the village chief spoke since he had had problems in his family related to the tradition." 
Near the end of January, Demba and Cheikh invited Tostan to come to visit some of these villages. They felt it was important to see the progress they had made, for as they indicated: "One year earlier, you could have been killed if you had brought up these subjects with these people." In each village visited, the men and women spoke of FGC, again with some reservation but with frankness nonetheless. They spoke of their desire to participate in the education program, for they had learned things from Demba Diawara and Cheikh Traoré about which they were totally unaware.

In the village of Fajal, we met with 66 year old Fatou Kinć Diawara, Demba Diawara's sister:

"I used to care for the girls after they underwent the operation," she explained in front of others, "then my own niece came for her operation and afterwards there were real problems. She was bleeding and the bleeding wouldn't stop. I tried everything I could think of with no luck. I was scared to take her anywhere for fear they would arrest me and put me in jail. I thought it was illegal to perform FGC, so I didn't want to take her to the hospital. Finally at about 4 PM the Imam came and he said some blessings. The bleeding stopped eventually, but my niece has never been the same since. She has some mental problems and look how thin she is."

In this same village of Faajal, a young man spoke up boldly: "We men would like to see the end of 'the tradition' because to tell you the truth - we're TIRED. We want our wives to have sexual pleasure... but it takes so much effort, that we sometimes just give up. Many times men in our ethnic group marry a second wife from an ethnic group which does not do circumcision for this very reason." There was much nervous laughter following his remark.

Most of the women from these villages expressed the fear that their daughters might become pregnant if they did not undergo the operation. Others in the group responded that they had seen many cases of circumcised girls getting pregnant, that this was no longer a solution to the problem of early pregnancy. Many said they needed education classes to be able to teach their daughters about health and sexuality and that their daughters also needed this information from formal school.

One 30 year old woman, Bileau Diawara, described her experience with FGC: "About twenty years ago, my mother came and told me to get ready to go to Thiès for a visit. My older sister was to go too. We arrived and almost immediately were taken to a compound unfamiliar to us both. Nothing was said to us. Suddenly, several women grabbed me and held me down on a mat in the back of the kitchen hut. I was frightened especially since I had no idea of what was happening. A woman came with a razor blade and told me that $I$ must not shed a tear. She told me it would be a disgrace, a dishonor to my family if I cried out. I was petrified but couldn't move. She cut me and I felt terrible, terrible pain but did not dare to cry or scream. For 2 days I would not urinate until I was forced to do so despite the burning pain. My sister and I were in a special hut and many women came to visit us. They sang and clapped and said we were brave. They said that now we were real women. This helped to take the pain away.

"When I was in high school, our teacher taught us about FGC. As she spoke, I realized that that was what had happened to me. Until then, I never realized that I was different from other girls. I remember being very, very angry. I went home that 
day and yelled at my mother. 'How could you have done this to me? You have ruined my life.' She looked at me calmly and said: 'You will thank me when you go looking for a husband.' The irony is that I married a Wolof man. Now I want to help Demba Diawara convince the others in the village to stop. He could do this where as no one would have ever listened to me!"

The people from these 10 villages all expressed the desire to meet together as a united community of villages with designated representatives: the village chief and two women. They chose the weekend of February 14-15, 1998 to hold this meeting. Tostan made it clear that we did not expect them to make any definite decisions at this time. In fact, we let them know that if at a later date they did choose to end FGC, we could hold another day when more people could attend and be part of the public declaration.

On the appointed day, the women from Malicounda and Nguerigne Bambara were late in arriving. When they finally walked in the door, there were enormous smiles on their faces and a sense of relief in their attitudes, a normal reaction after the months of tension they had experienced. They knew that some of their trials were over since they were being received as honored and courageous guests in this seminar uniting other members of their own Bambara ethnic group.

The Diabougou meeting began with testimonies of the women, then the opinion of two religious leaders, one from Nguerigne Bambara, the other a member of the "Kounta" maraboutic family, the most respected of the religious leaders for the Bambara ethnic group in Senegal. A health worker gave clear explanations of the dangers of Female Genital Cutting which interested everyone. Questions were asked by the participants. The President of the National Organization for Human Rights, a Bambara himself, Sidiki Kaba, spoke about Female Genital Cutting and why it was a violation of human rights, particularly children's rights. The Director of the Cabinet, Cheikh Tidiane Diop, from the Ministry of Women, Family and Children spoke on behalf of the Government. The villagers greatly appreciated the presence of a higher, respected government official at their seminar. The villagers asked more questions and shared other information and stories.

The "outside" guests left Diabougou to give the representatives of the 13 villages (approximately 50 people), the time to discuss among themselves in Bambara at approximately 3 PM.

When Tostan returned at $2 \mathrm{AM}$ to meet with the representatives of the villages, they had prepared the Diabougou Declaration, discussed in Bambara and originally written by them in Wolof. We spent 2 hours translating the declaration into French in collaboration with several of the villagers. Melching noticed as she worked on the translation that they had mentioned nothing about alternative initiation rites, a point which had been brought up as a possibility before the meeting.

"Why is this?" Melching asked the women.

"Oh we decided unanimously NOT to call for alternative initiation rites. We need to do away with these rites altogether. We need a means of controlling what goes on and if you have the drumming and singing, it will be associated with cutting. People will use this pretext to cut in secret. This must end."

One woman added, "Let's be honest, we were cutting our girls at 2 weeks to 3 months over the past years so this was not even part of the ritual any longer. This is a 
romantic notion you westerners have and want to impose on us now!" The women instead called for education classes to teach responsibility, problem-solving, health, and sexuality. They said they would talk to the older women and tell them the importance of passing down traditions and the cultural information related to their ethnic group. They were adamant in their decision.

The women who had performed the cutting operations all announced that they were ready to stop the practice, even if it meant losing money,

They had also integrated the strong statement of Fatou Kiné Diawara who had so often declared: "A tradition which harms, a tradition which kills, should not be a tradition." The other guests were invited to return to the village the following morning at $11 \mathrm{AM}$ and the villagers read their declaration:

\section{THE DIABOUGOU DECLARATION}

We, the 50 representatives of more than 8000 people residing in the 13 villages of :

$\begin{array}{llll}\text { Keur Simbara } & \text { Diabougou } & \text { Soudiane } & \text { Sorabougou } \\ \text { Bagana } & \text { Baboucar } & \text { Kobongoy } & \text { Fajal } \\ \text { Medina Fajal } & \text { Samba Dia } & \text { Samba Diallo } \\ \text { Ngeriñ Bambara } & & \text { Malicounda Bambara }\end{array}$

meeting in the village of Diabougou (Region of Thiès) from February 14-15, 1998 to discuss the practice of Female Circumcision in the Bambara community:

- Considering the numerous testimonies of the women and girls in our community, in other localities of Senegal and in numerous African countries which affirm that Female Circumcision can be a source of suffering, illness, psychological trauma and even loss of human life;

- $\quad$ Considering the reports of health workers who have established that Female Circumcision is often the source of medical problems for girls and women who undergo this practice and can cause: heavy bleeding, which can lead to death, infection, infertility, complications during and after childbirth, sexually transmitted diseases or AIDS and mental health problems, etc.

- Considering the religious values of our community which affirm the importance of the physical and psychological health of women and guarantee the right to health;

- $\quad$ Considering the different international conventions and charters relating to Human Rights which stipulate that Female Circumcision is a violation of the human rights of girl children and women;

- Considering that the Government of Senegal, through the voice of the President of the Republic himself, has taken a firm stand against the practice of Female Circumcision in order to protect the health of girls and women and to comply with the commitment of the Government of Senegal to enforce the international declarations, conventions and charters they have ratified;

- Affirming that traditions should be positive and beneficial for the individual and for society and not be a source of suffering, trauma, illness or death;

- Affirming that women play an essential role in our society and should, consequently, benefit from the best possible state of health at all stages of their lives; 


\section{DECLARE :}

\section{community.}

Our firm commitment to end the practice of Female Circumcision in our

Our firm commitment to spread our knowledge and the spirit of our decision to our respective villages and to other communities still practicing Female Circumcision.

We also wish to continue the process of consciousness-raising and social transformation begun during this experience by benefiting from a Basic Education Program which will allow us to acquire reading, writing and math skills as well as to obtain information on health, hygiene, problem-solving, management, leadership, human rights and democracy.

We would like to take this opportunity to express our deep appreciation and gratitude to the women of Malicounda Bambara, Ngeriñ Bambara and Keur Simbara who, under difficult circumstances, led the way and indicated the path to follow for the government and other communities who are committed to assuring that girl children and women will no longer be subjected to the dangers of Female Circumcision. Our meeting here in Diabougou today is the result of the determination of these courageous women.

We also would like to thank President Abdou Diouf who, through his personal appeal for the abolition of Female Circumcision, an extremely sensitive subject in our country, showed courage and resolve by appealing to the national community to perpetuate the process which led to the Malicounda Commitment.

We express our gratitude to Tostan, UNICEF, the Minister of Women, Children and the Family, the Minister of Ilealth and Social Action, the National Organization for Human Rights (ONDH), UNIFEM, FNUAP, and OMS for their numerous activities related to this field. We ask that they continue to support and accompany us in our efforts to eradicate Female Circumcision.

Because education is at the heart of this historic encounter in Diabougou and recognizing that basic education is a necessary element for the promotion of the individual and of society in general, we appeal to the Government to assist us in beginning a program for basic education in national languages in the ten villages not previously having benefited from such a program.

We make a solemn appeal to the national and international community to quickly mobilize their efforts to assure that girl children and women will no longer suffer the negative health effects associated with Female Circumcision.

We wish finally to thank our traditional and religious leaders, our government representatives and all the women, men and young people who have actively participated and supported us in our initiative.

The 50 Representatives of 8,000 people residing in 13 villages in the Regions of Thiès and Fatick

DIABOUGOU, SENEGAL

February 15, 1998 
The Director of the Cabinet of the Ministry of the Family made pertinent congratulatory remarks and there was traditional Bambara singing and dancing that continued long after the official guests had left. When Tostan went to say good-bye to the village representatives, we found them in a heated debate in one of the school classrooms. They were making up a plan for follow-through of their decision and were trying to decide what penalties should be applied if anyone transgressed the new pledge. Some felt it was important to pursue these cases before the law. Demba Diawara argued that education and persuasion are the best methods for bringing about lasting change. They all agreed that any form of "turning back" would be shameful and cast disgrace on the honor of their group. Over and over villagers stated: "Once a Bambara makes up his or her mind, that's it. It takes us a while to decide, but when we do, it sticks."

Their decision was on television, in the newspapers and on the radio, bringing the issue once again to national attention.

On December 23, Melching visited 3 of the villages which participated in the Diabougou Declaration. Tostan, with the support of UNICEF, has now opened classes in the ten villages and she met with the village chiefs, local authorities and the 70 women participants of the class. In all the villages, the people told her that the practice of FGC has ended for good and that there have been no cases of genital cutting in the ten villages since their declaration on February 15.

\section{MRS. CLINTON LENDS SUPPORT TO THE MOVEMENT}

The First Lady of the United States, Mrs. Hillary Rodham Clinton, first came to Senegal from March 17-18, 1997. At that time, she visited the village of Saam Njaay where Molly Melching had lived from 1982-85 under an experimental education project funded by USAID. During the following year, Melching wrote often to Mrs. Clinton of the extraordinary events she was experiencing concerning the issue of Female Genital Cutting and received support and encouragement from the White House. When Mrs. Clinton returned to Senegal with her husband, President William Jefferson Clinton in April of 1998, she asked to meet with and congratulate the courageous people who had led this movement against Female Genital Cutting. On April 2, the women of the class of Malicounda Bambara, Demba Diawara, Cheikh Traoré (Keur Simbara) and Ourèye Sall (Ngeurigne Bambara) all came to the Méridien Hotel where the Presidential couple was staying to meet with the First Lady.

Preparation for this event had been difficult. The men in Malicounda were once again skeptical. "You'll go there and be used by people. You will never even get to see the First Lady let alone MEET her!" they warned the women. The men tried to convince them not to go. One man ordered his wife to stay home at the last minute, despite her active participation in the class and in the movement to end FGC. The women decided it was too late to protest his decision and left despondent and worried.

The arrival of the First Lady in the hotel meeting room quickly dispelled all fears. Mrs. Clinton shook hands with each participant, greeting them warmly and thanking them for making the trip from the village to come meet with her. The White House had carefully prepared the event and all villagers had headphones for simultaneous interpretation in Wolof and English. 
The Minister of Women, Children and the Family, Aminata Mbengue Ndiaye, as well as three other women who have participated in the fight to end FGC in Senegal: Marianne Ndiaye Sidibé, Marie Hélène Mottin Sylla and Awa Thiam were also present for the round table. Mrs. Khadidia Sidibé, President of the Association for the Follow-up and Orientation of Traditional Customs (AMSOPT) in Mali participated, as well as Molly Melching and Maïmuna Mills from the Voice of America who was the moderator for the panel.

The President of the Women's Group from Malicounda Bambara, Maïmuna Traoré, began the discussion by giving a brief description of how the women, inspired by their basic education classes, took the initiative to inform the other men, women and children of their village of the health dangers associated with FGC and the need to abolish this tradition. She explained that although there was considerable resistance by other members of their ethnic group to their public declaration to end FGC on July 31,1997 , the women never retracted, using their knowledge of human rights and the negative health consequences as arguments.

The women of the education class of Malicounda Bambara then presented a short play in which a village girl dies from the FGC procedure and which demonstrates the complexities of changing mentalities and traditions, despite the real dangers indicated in the play.

Ourèye Sall from Ngeriñ Bambara, another village then explained that she had actually lived through what Mrs. Clinton witnessed in the play. She noted that non-formal education is the means to changing mentalitics and cncourage problem-solving and improved socio-economic conditions by the villagers themselves.

Demba Diawara, the imam, discussed the point of view of Islam which in no way obliges women to practice FGC. He also thanked Ms. Clinton for her support in seeking to protect the health and human rights of African women and children.

The Minister of Women, Children and the Family, Aminata Mbengue Ndiaye thanked UNICEF for their support of the Tostan basic education class which led to these results, as well as the other women representing organizations active in the struggle to end FGC present at the round table (ENDA, COSEPRAT et Femmes et Sociéte). She read part of the President of Senegal's Declaration encouraging an end to FGC and inciting other villages to follow the Malicounda example, then discussed the importance of the Diabougou Declaration and the law against FGC initiated by the government of Senegal on February 3, 1998.

Madame Khadidia Sidibé from Mali spoke of the higher incidence of FGC in Mali $(95 \%)$ and of the accomplishments of her and other organizations in the struggle to end this harmful traditional practice. She noted that Ms. Clinton's interest in this issue would help to encourage the women in Mali and other West African countries to put an end to the practice.

Molly Melching thanked Ms. Clinton for the support she had demonstrated over the past year for the women of Malicounda Bambara which helped to encourage them during difficult times. Melching emphasized the importance of basic education and knowledge of human rights in empowering women to make critical decisions which affect their lives and those of their children.

Ms. Clinton then praised the villagers for starting "a great movement" and told them that she had written an article on their experience. "It was not easy for women 
and men to come together to stand against and speak out against a key ancient custom. The courage and commitment of the women, the men and the religious leaders of Malicounda has served now as an example to bring together thousands and thousands of other Senegalese," she said. According to Ms. Clinton, basic education is necessary for empowering women in all areas.

At the end of the round table, Ms. Clinton held the women's babies and pictures were taken of the participants. Ms. Clinton then invited everyone to participate in the Human Rights round table presided by her husband, President Clinton. During that meeting with human rights leaders from different African countries, Ms. Clinton spoke of the contribution the women from Malicounda had made to human rights at the grassroots level and asked them to stand. They were applauded enthusiastically by the numerous participants from all over Africa.

The women met President Clinton after this round table and he congratulated them on their decision and their courage. He also praised the work accomplished by the NGO Tostan. The White House later sent pictures of the women with President and Mrs. Clinton which were given to the villagers and shown in other villages by Demba Diawara during public meetings.

This unusual event was shown on television and once again helped to influence public opinion in Senegal. Tostan received many phone calls from around the country where people commented on the great respect shown to the villagers. Many noted that Ms. Clinton did not attack the tradition of FGC but rather congratulated the villagers themselves for having done so, indicating her interest in promoting girls' and women's health in Africa.

The warm reception of the women of Malicounda Bambara by the First Lady also helped lead to a change in mentality of the men of the village who suddenly realized that the women were indeed at the origin of an historic movement. At a human rights training held by Tostan, UNICEF, ONDH and UNIFEM for the community of Malicounda Bambara in May of 1998, the man who had forbidden his wife to attend the Presidential event publicly apologized to the entire village.

Ms. Clinton's public support of this issue clearly helped draw more international attention to the issue of Female Genital Cutting.

\section{ENDING FGC IN KOLDA - THE MOVEMENT TAKES ON NEW MOMENTUM}

Tostan translated the Diabougou declaration into Pulaar in February, 1998 and sent it to the Kolda region where 14 villages were participating in Module 8 on Early Childhood Development. In the Department of Kolda, $88 \%$ of the population practice Female Genital Cutting. Tostan has been in this zone since 1989 and particularly in the larger village of Medina Cherif which is known for being both very traditional and religious.

The Diabougou Declaration was discussed in class during the sessions on Female Genital Cutting and there was much debate on the subject. When Bilal Ndiaye went to evaluate the module in collaboration with the two trainers, the villagers of Medina Cherif told him that after studying the module and learning about the negative health effects of FGC, they had made the decision to end the practice. 
Tostan was startled by this decision, since they had a previous experience in two Pulaar villages participating in Modules 7 and 8 and found that although the women had made the decision to stop the practice, they did not want to say anything about it publicly. Tostan naturally respected this decision and never spoke of it again, assuming that the Fulaani group was more reserved than the Bambaras. Thus the desire of the Fulaanis of Medina Cherif to make a public announcement was surprising, especially coming from a particularly religious and conservative village. Once again, the decision was made in collaboration with the class, the village chief, the men and the Imam. When the three villages surrounding Medina Cherif heard of this decision, they quickly decided to stop also, given that they are related and closely collaborate on all activities. Tostan decided to hold a seminar for these four villages and found that the 10 other villages which had participated in the program quickly met to discuss the topic and then asked to attend the seminar also. Four other nearby villages also wanted to be part of the meeting even though they had not been involved in the education classes. Members of the class had been to their villages to inform them of the decision and explain how it came about which led to their request to be part of the movement.

Their meeting was held from June 1-2 and was attended by three representatives from each village, including the village chief and 2 women representatives. Local religious leaders were also invited and spoke with great conviction. The wife of the village chief, Talata Baldé had died one week earlier and the village chief let us know how much she had supported the women's decision to end this practice. "My wife's name is Talata (meaning Tuesday)" the chief told me, "She was born on Tuesday, she died on a Tuesday and now our big seminar is being held on a Tuesday! She would have been so proud of our village on this day!" For this reason, the seminar was called the "Talata Baldé Encounter of Medina Cherif" and the meeting was dedicated to her memory.

The young President of the Women's Group in Medina Cherif, Fatou Lala Baldé, is a very intelligent, strong, influential woman. The story she told at the seminar of her own daughter who had hemorrhaged when she was circumcised with 10 other girls at the age of four touched everyone deeply. "Look at her now", she said as she called up her daughter, "she is nine but looks like she's four. She has not been the same since. Imagine such a young girl having these health problems. I feel so bad. At the time, I thought evil spirits had caused her to bleed, now I know otherwise." Lala explained that the class participants went to speak with the village chief and Imam immediately following the session on Female Genital Cutting. "We all cried together that day," she said.

The representatives from the other 17 villages also spoke. One traditional cutter and President of the Association of cutters in the nearby town of Velingara, Talla Coulibaly, talked of the need to give cutters projects to compensate them for their lost work. Tostan had heard of such projects before, but had never encouraged it in the villages ending FGC which had been involved in the education program, believing that educating the people themselves was a far more sustainable solution then focusing on the cutters and trying to get them to stop.

A woman of the Mandinka ethnic group, Dado Boiro, who had done circumcision in the surrounding villages answered this woman: 
"I have heard that some cutters have asked for projects or money to stop this practice. I don't ask for money, I ask for forgiveness for having caused girls and women such suffering in their lives. We will now be like all the other women in the village who together must work to create income generating projects."

"We must be honest about this," another cutter added, "We have seen girls die from this practice. At the time we thought that bad spirits were the cause of these girls' deaths. Now that we have learned the real cause, we must stop."

Sekou Baldé, a health educator representing the Ministry of Health in the Department of Kolda spoke of the health problems he encountcred daily which are linked to the practice of FGC. According to a later interview with Mr. Baldé, a study done in the department of Kolda revealed that $88 \%$ of women in the department practice FGC and $79 \%$ have have had problems related to the practice.

The village chief, Thiekoto Baldé, and the highly respected religious leader in Medina Cherif, Thierno Ibrahima Bah, both spoke eloquently of the need to end FGC given the health risks involved.

The representatives of the villagers met during the afternoon to discuss the declaration they would draft to publicly confirm their commitment to end Female Genital Cutting in the 18 villages. Their declaration was read on June 2, 1998 accompanied by traditional singing and dancing.

\section{MEDINA CHERIF DECL $\Lambda$ RATION}

We the following 18 villages in the Fulado, region of Kolda:

\begin{tabular}{|c|c|}
\hline Saaré Moody & Saaré Mandy \\
\hline Saaré Maoundé & Goundaga \\
\hline Saaré Kaasoum & Duuta Diaara \\
\hline Sankaaña & Saaré Waly \\
\hline Mampatim & Saaré Demba Moody \\
\hline Neema Kunda & Mbaalo Kunda \\
\hline Saaré Ansou & Saaré Yéro Kidiera \\
\hline Saaré Kadri & Saaré Abibou \\
\hline Sinthian Aladji & Médina Chérif \\
\hline
\end{tabular}

meeting on the first and second days of June, 1998 to discuss the question of Female Circumcision and taking into account the following considerations:

- the numerous testimonies of girls, women and cutters relating the dangerous consequences of this practicc;

- the opinion of religious leaders indicating the position of Islam which guaranties and defends the right to health and human dignity, and which attaches particular importance to women and children;

- the information provided by health and human rights specialists; 


\section{have made the conscious decision to definitively renounce the practice of Female Circumcision}

which is a source of multiple health dangers and constitutes a violation of the fundamental rights of our girls. We have taken this decision in order to assure the respect of girls' rights to health, bodily integrity and human dignity.

With this historic decision, we hereby join the great movement to end Female Circumcision which began in Malicounda Bambara. In that community, Amazons led the way to achieving the respect of the rights to health and dignity for all girls and were able to withstand the numerous pressures resulting from their courageous decision.

Since that time, the flag of the women of Malicounda was raised even higher in Diabougou.

Today, we the populations of the Fuladu, have made the decision to continue the struggle initiated in Malicounda Bambara and thus contribute to the abolition of this practice in our country, in Africa and throughout the world.

Furthermore, we affirm that our present declaration was made possible because of our participation in the Tostan/UNICEF basic education program of which human rights education is a major component.

We today renounce the practice of Female Circumcision. We nonetheless solemnly reaffirm our strong and deep attachment to the perpetuation of all our positive traditions and values and our aspiration for an education program for our girls so that they, in turn, will be able to assure, respect and promote the rights of their future children. We request such a program for our children and are certain that our appeal will be heard by the Government of our country, particularly the Ministry of Women, Children and the Family which is deeply committed to the promotion of women and children, and by our other partners in development to whom we express our deep gratitude.

We extend special thanks to Tostan UNICEF, and AJWS, but also thank all participants who have shared these important moments with us here today and who have witncssed committed citizens engaged in a struggle to assure a better future for their children. 


\section{PUBLIC PLEDGES MAKE A DIFFERENCE}

Many additional articles appeared in the local Senegalese newspapers and the Medina Cherif Declaration was broadcast over the radio and television. The Senegalese public was now becoming more and more aware that a large grassroots movement to end Female Genital Cutting was taking place in their country. One well-known Mandinka traditionalist, Mr. Doudou Camara, who had initially been quite angry with Molly Melching for her involvement in an effort "to eliminate essential Mandinka traditions", started changing his attitude and told Melching that the women's statements in Kolda had made an impact on him. He was beginning to understand that the movement went beyond destroying traditions.

A member of the Toucouleur ethnic group (closely related to the Fulaani ethnic group), Mr. Ibrahima Ndiaye, who lives in Dakar and is head of an office at an international airlines, thanked Melching for the work Tostan had done in educating members of his own ethnic group. He explained that he was horrified with the amount of suffering his wife had to undergo because of this practice. "On our wedding night, I was unable to consummate the marriage because the opening was so small. A week later, her mother brought in the traditional cutter, who with her razor blade, cut my wife open so that we could have sexual relations. She was in great pain and said that if she had known that this is what marriage was, she would have never accepted. It isn't fair and I vowed my own daughters would never undergo the same ordeal. However, my father's aunt came one day while I was at work accompanied by the traditional cutter. When I arrived home that night, I sensed something awful had happened. No one came to meet me as usual. There was only silence and tears. My two girls had been circumcised that day without my knowledge or consent. I was so angry, that I told my aunt I would take her to the police. 'Go ahead' she cried 'I would rather go to the police than to see your daughters not circumcised! You will thank me when it's time for them to be married'."

"So you see," Mr. Ndiaye told Melching, "You are really helping me by showing my aunt that it is not only the intellectuals (associated with rejecting traditions) who are standing up against this needless suffering - it is also thousands of villagers who are the strongest defenders of our traditions. She will listen to them!"

Demba Diawara continued visiting Bambara villages from August through November, 1998. "I would go to a village and find everyone at the meeting! and they would tell me 'We were waiting for you to come! We could never have initiated these meetings alone. We have heard of your public pledges to end Female Genital Cutting. We want to join with the other Bambara villages who were not part of the declaration and end this practice also, but we could not do it alone. We were waiting for you to come!" Nine villages visited by Demba Diawara in the Thiès region have asked to hold a meeting in the near future to make a public declaration to end FGC: Ndiassane, Daaf, Njajaan, Tawa, Cawon Mbambara, Baaliga, Puut Mbambara and Toucouleur, Mbambara Karamoko, Mbambara Cherif, Xeramakono, and Keur Issa Mbambara. The highly respected religious leader of the Bambara ethnic group, Serigne El Hadj Bouna Kounta residing in Ndiassane, has told Demba Diawara he will personally support this effort. 


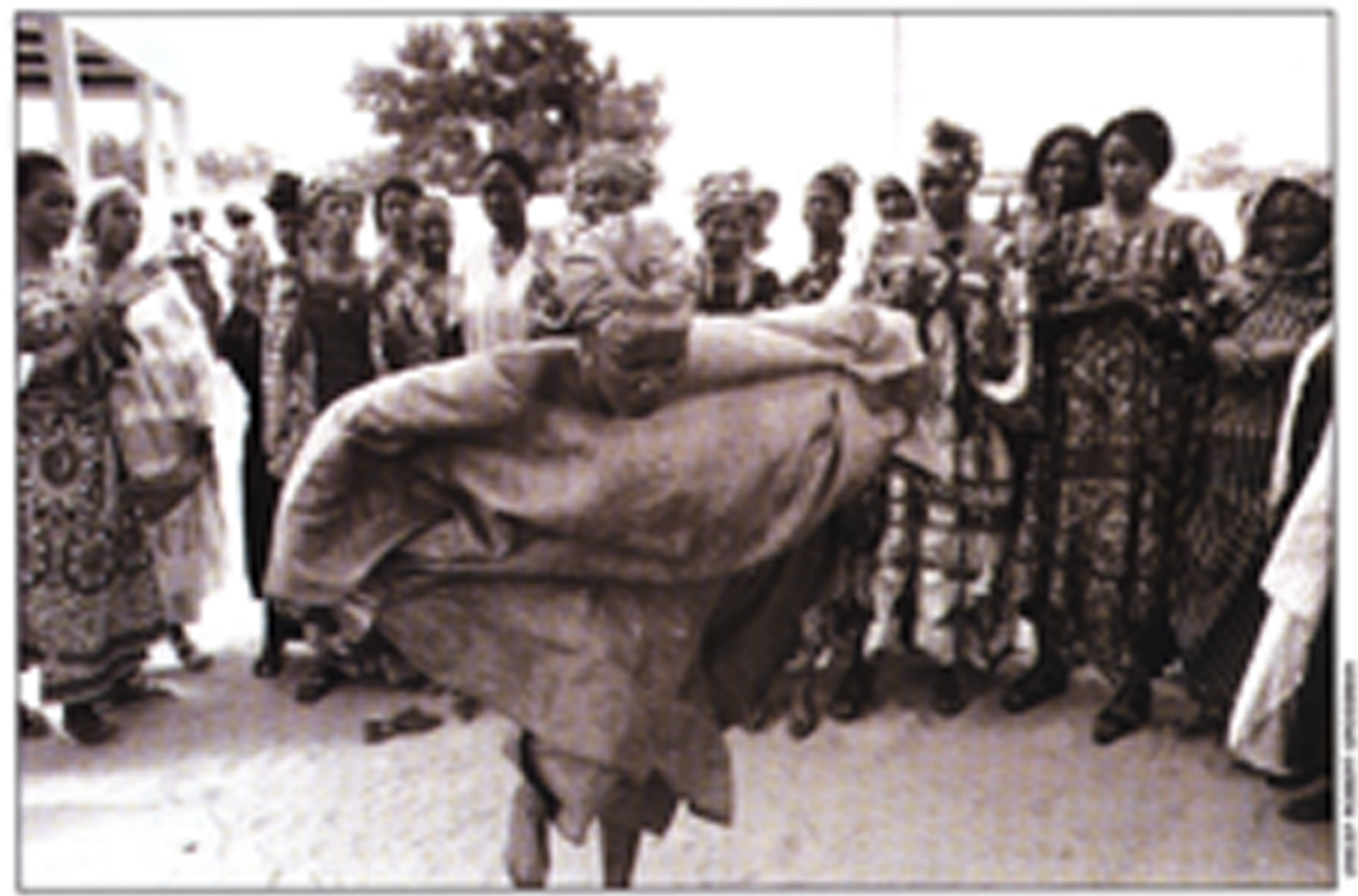

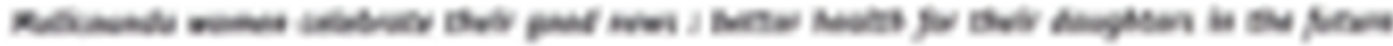




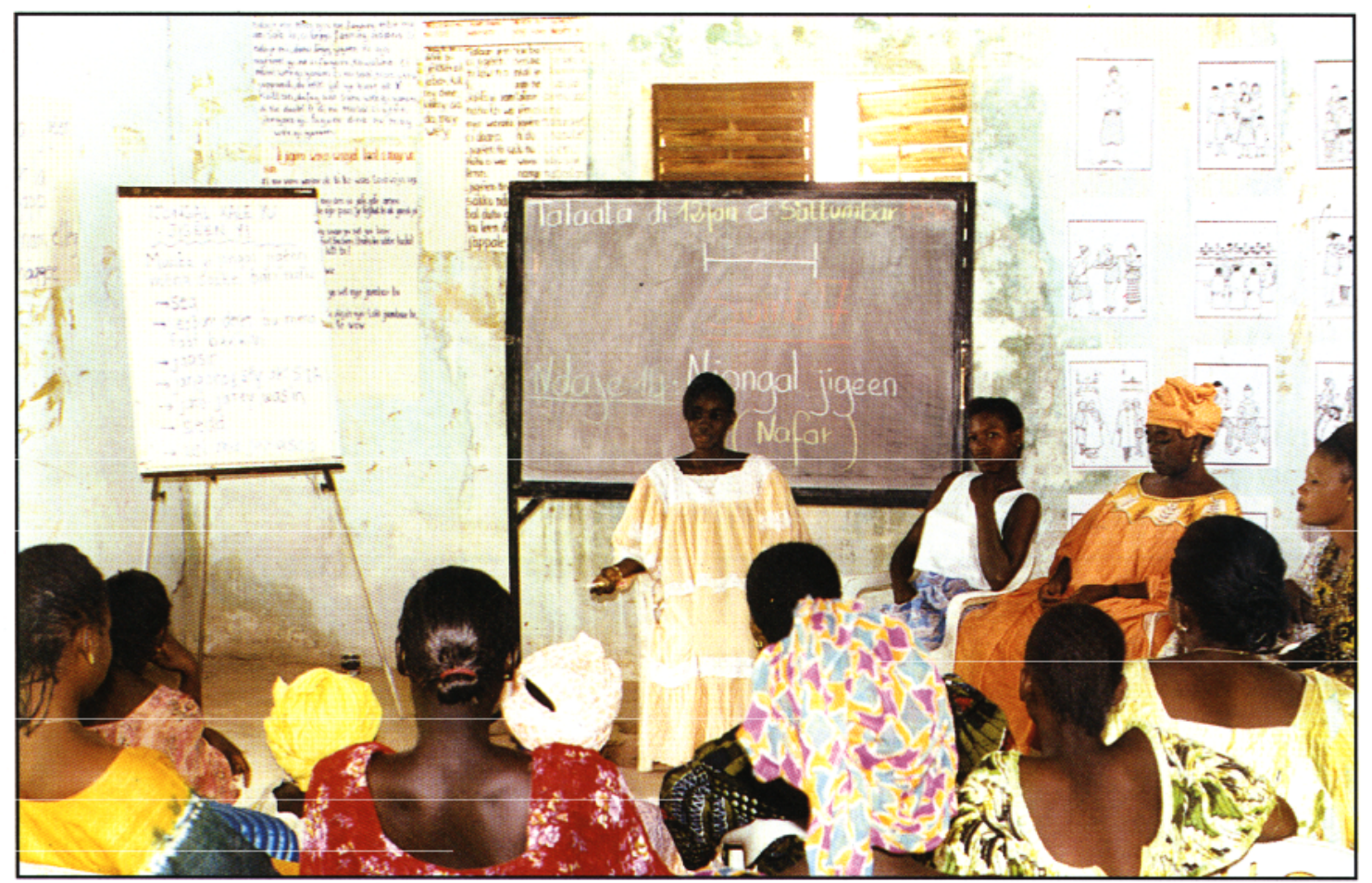

The women of Malicounda Bambara discuss Female Genital Cutting during Tostan module 7 on women's health

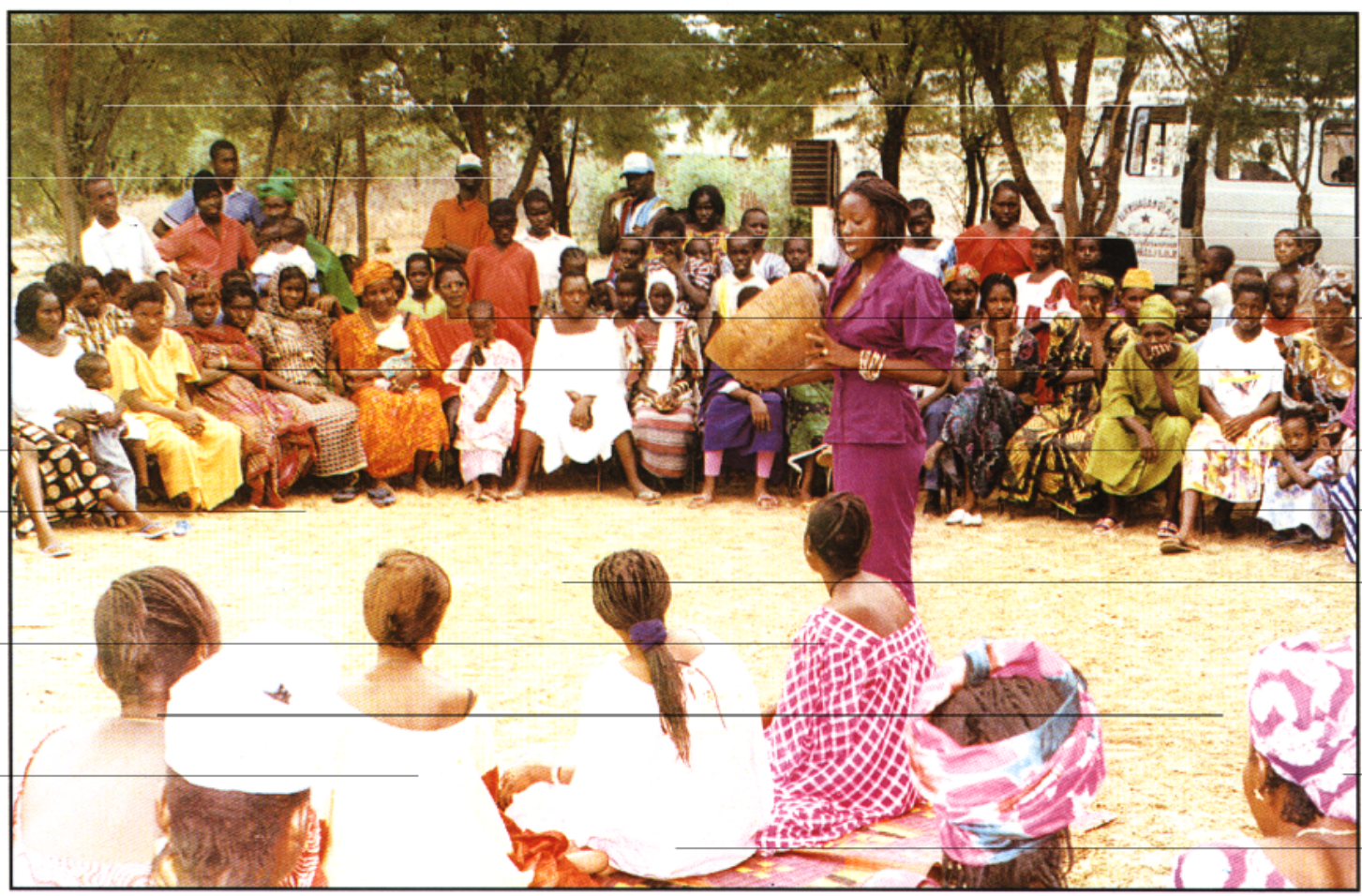

The class from Malicounda Bambara performs their theater for the villagers of Keur Simbara (August, 1997) 


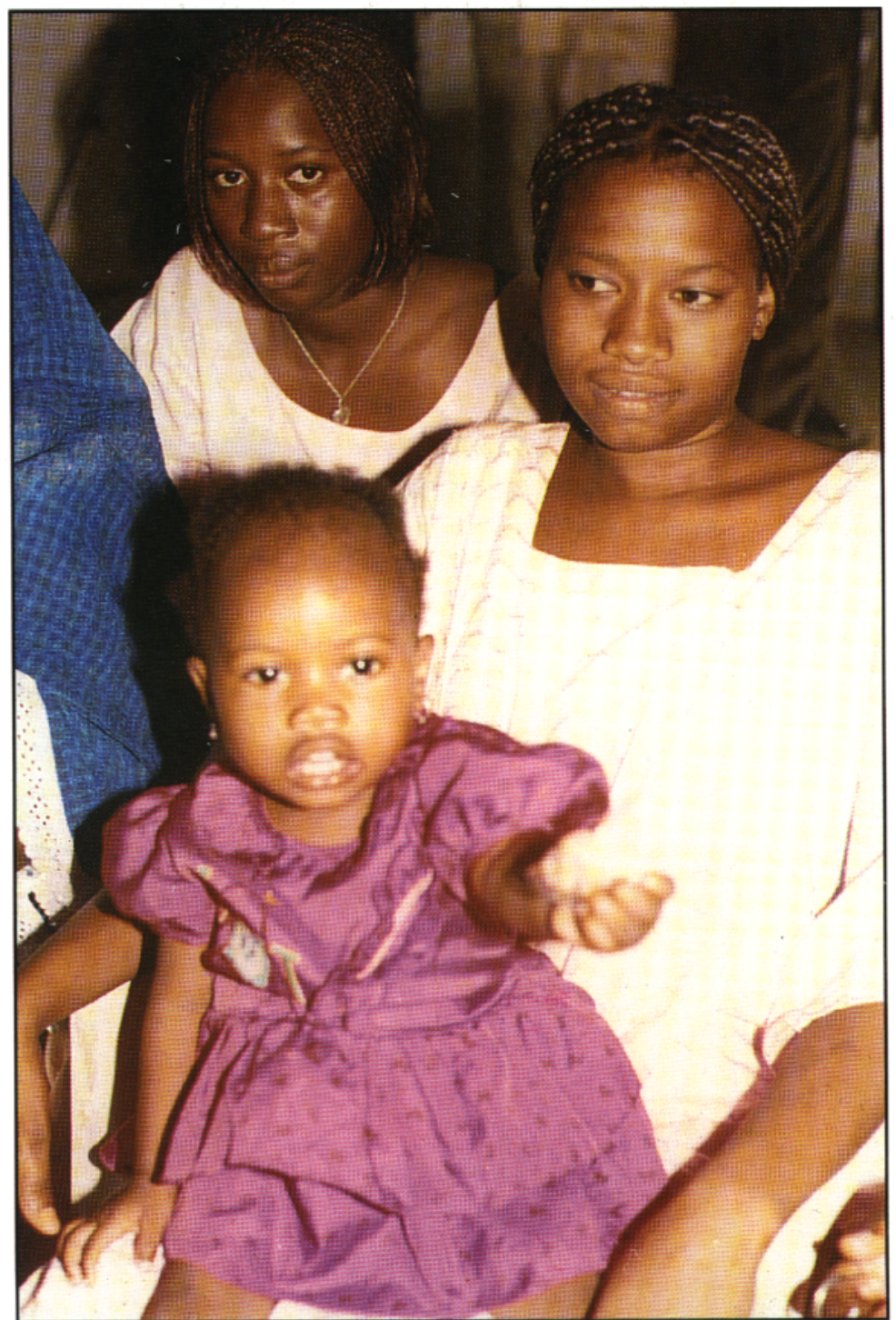

Alima Sañ-Sañ, (Alima Human Rights) the first baby girl to benefit from the decision to end Female Genital Cutting in Malicounda Bambara. 


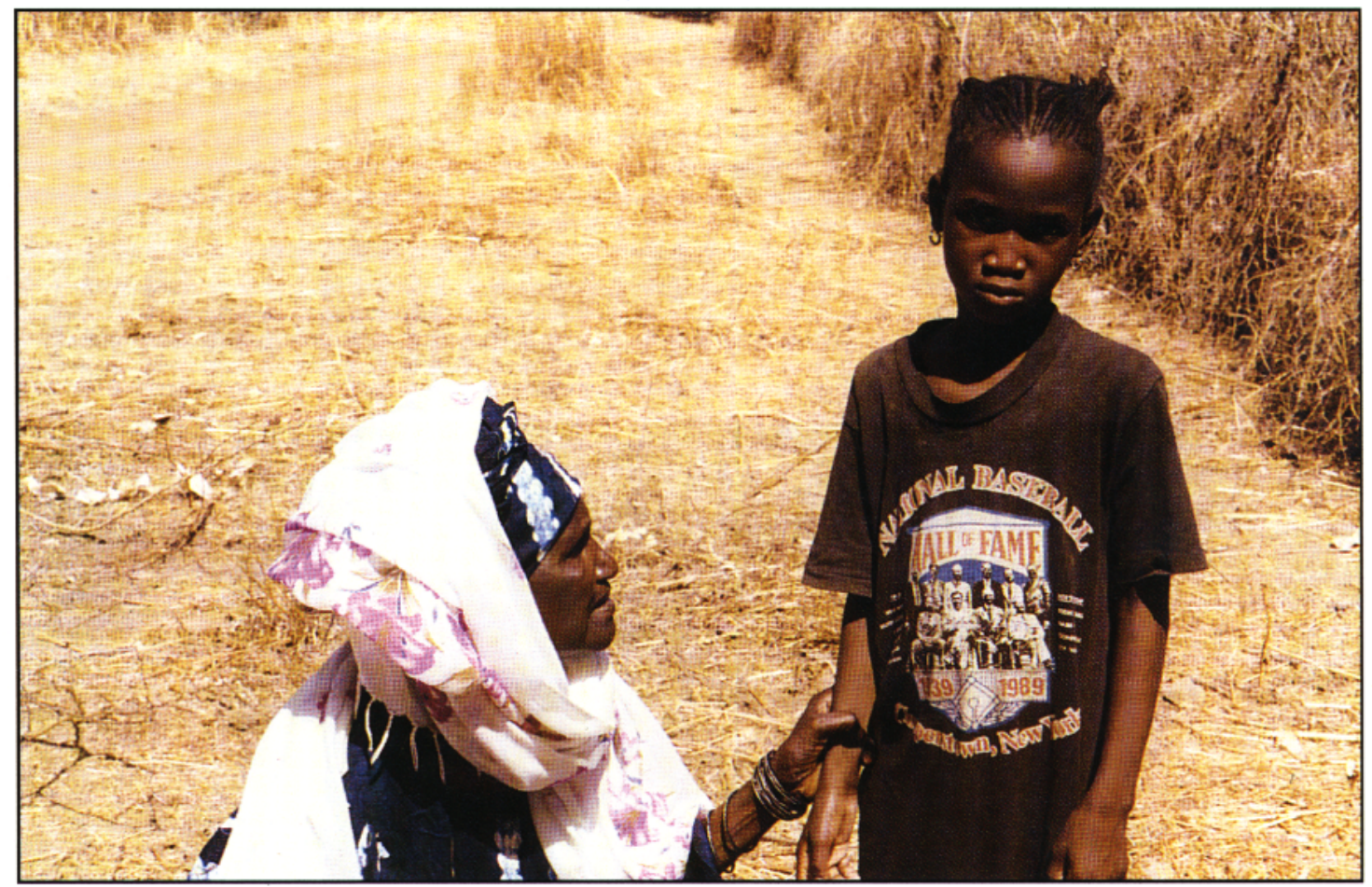

Fatou Kine Diawara deplores the fact that her great niece almost died during the cutting operation.

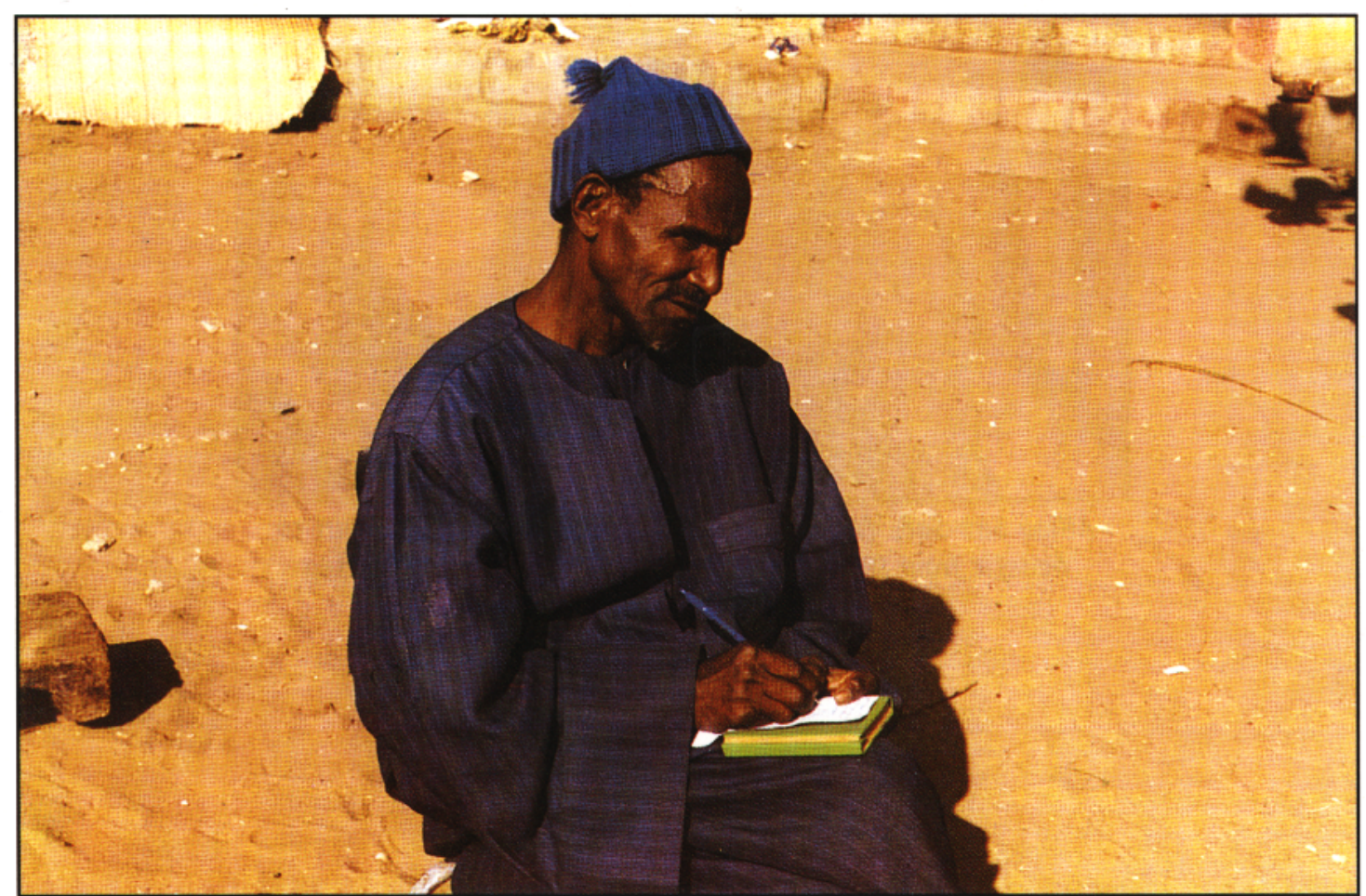

Demba Diawara, the Imam from Keur Simbara, has walked from village to village to discuss the negative health effects of FCG with his relatives. 


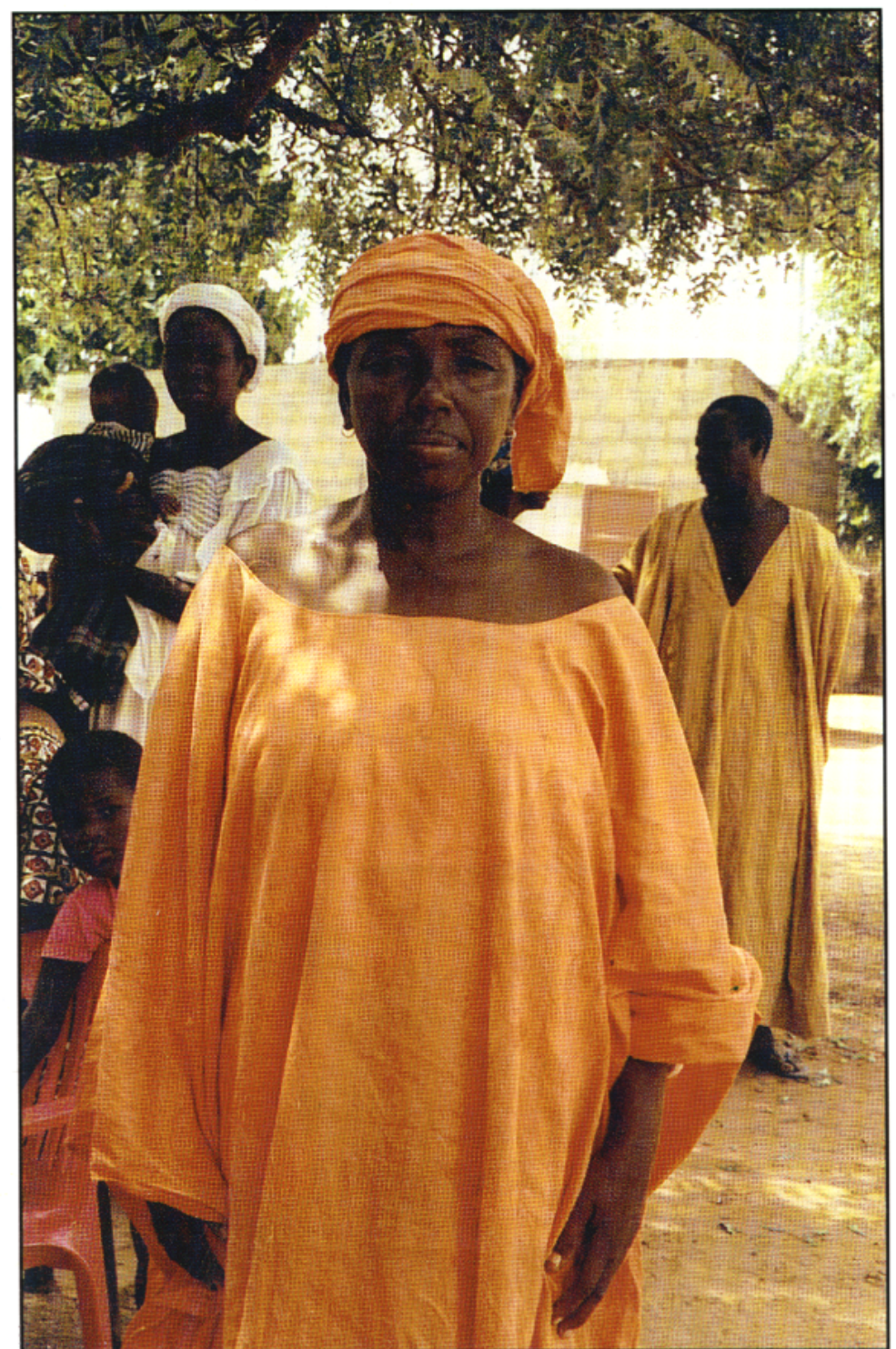

Ourèye Sall, the traditional cutter from Nguerigne Bambara, no longer pratices FCG. Other cutters from Tostan classes have followed her example. 


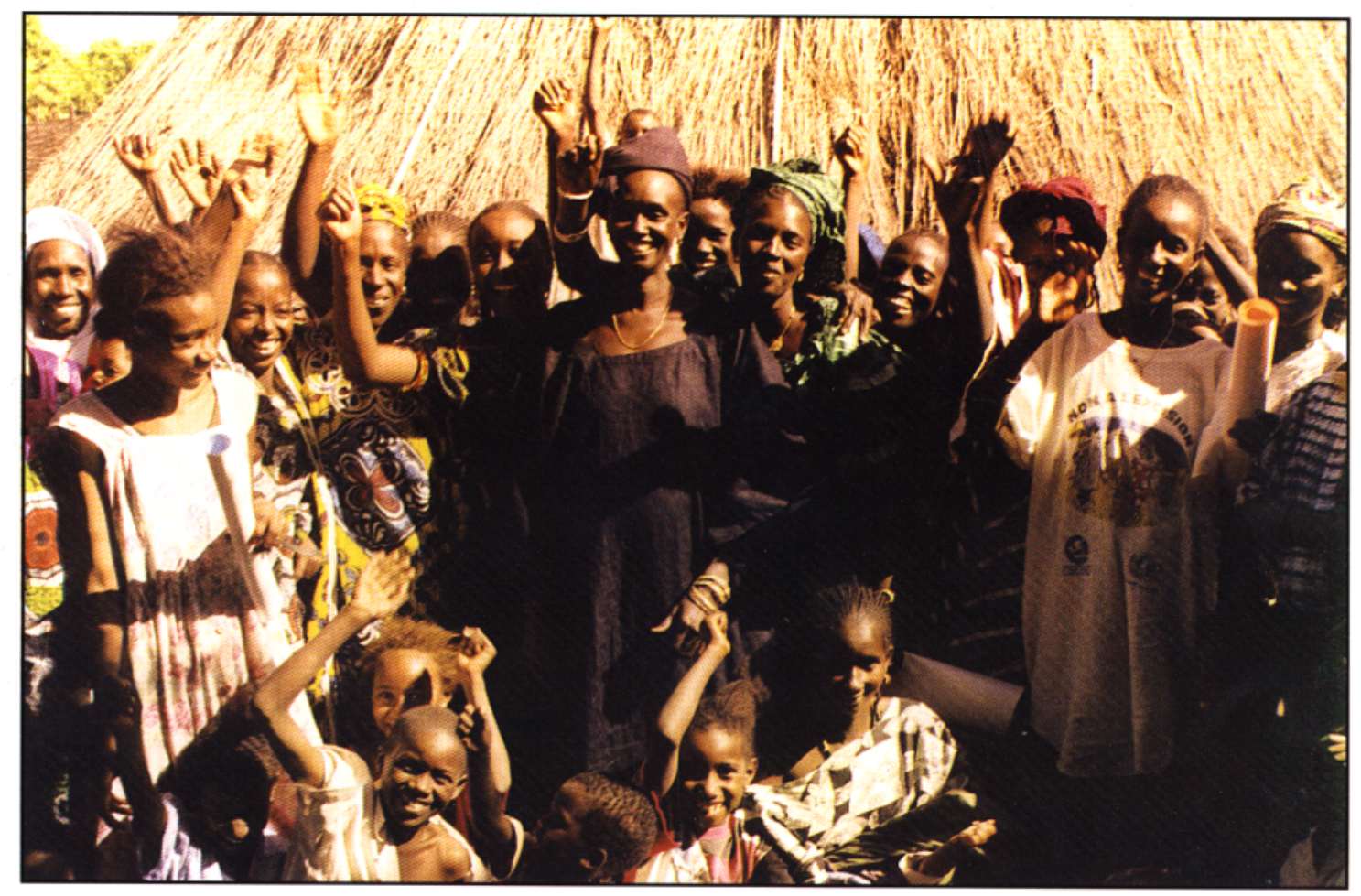

The women of Medina Cherif do not regret the important decision they made.

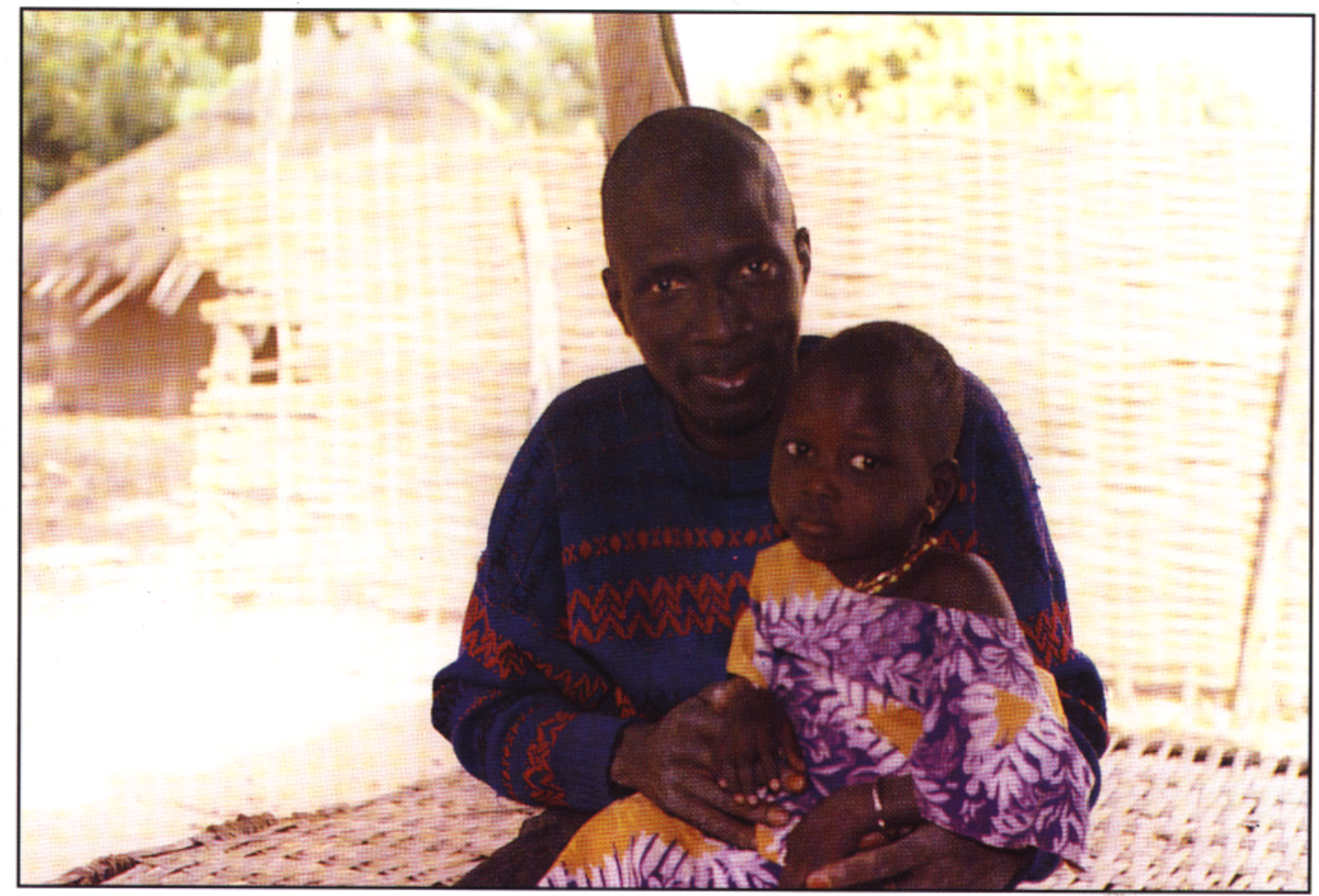

"My daughter will never be circumcised" says a man from Mampatim who participated in the Medina Cherif declaration from July 1-2 1998. 


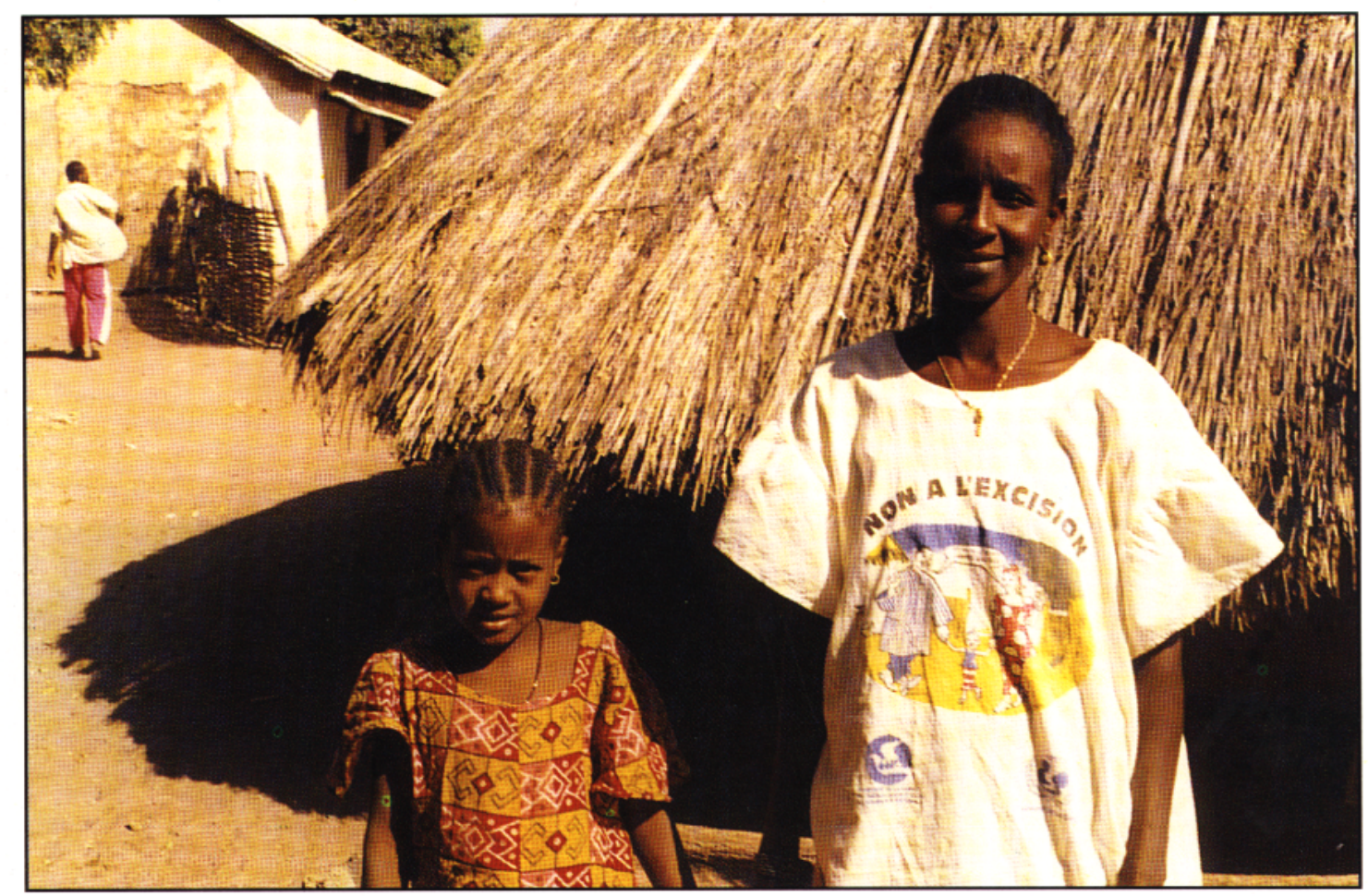

Lala Baldé traveled to Northern Senegal to explain why 18 villages in Kolda ended FGC.

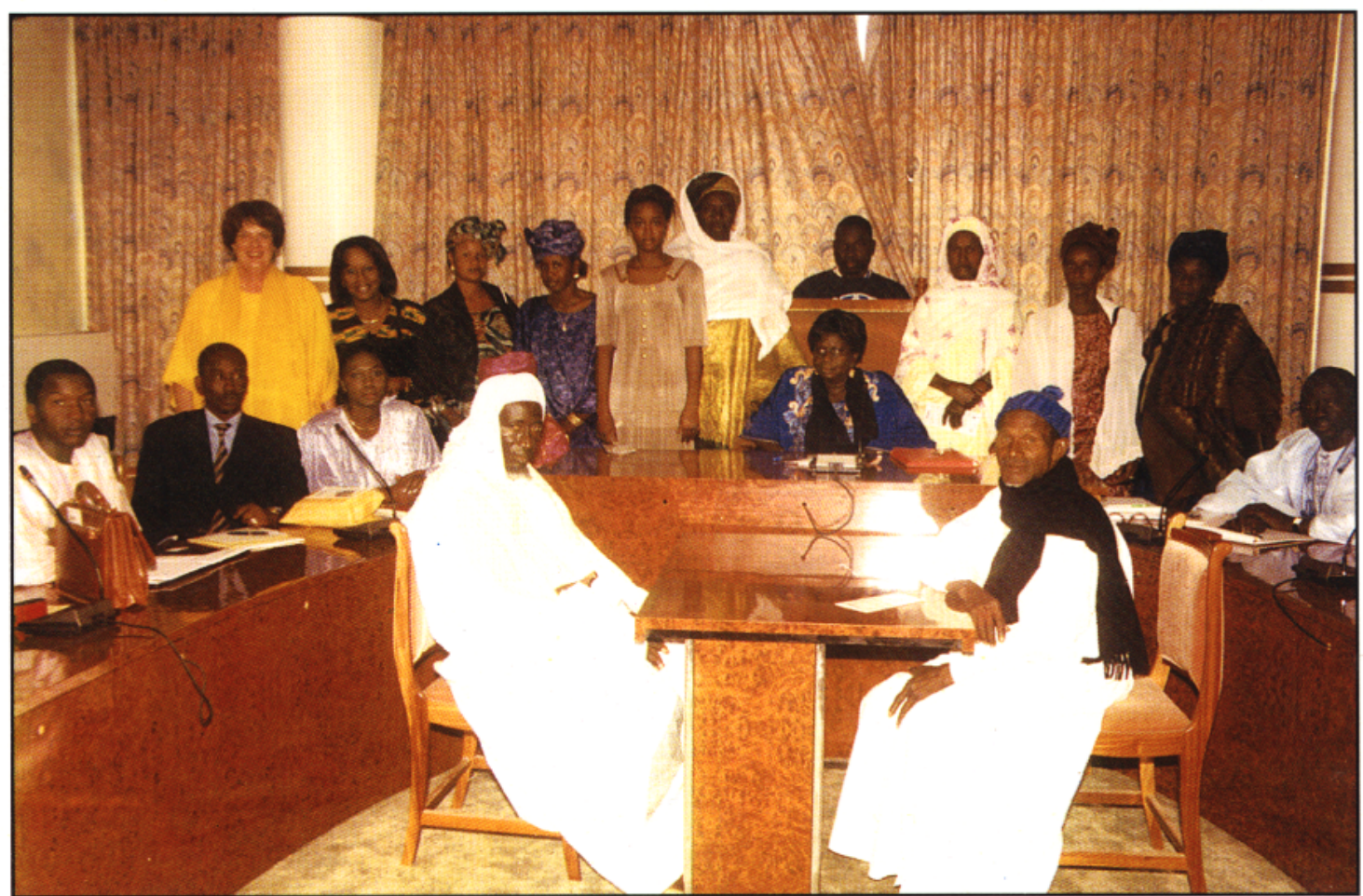

Thirteen villagers testified before members of parliament on January 12, 1999. The law to end FGC in Senegal was voted on January 13. 


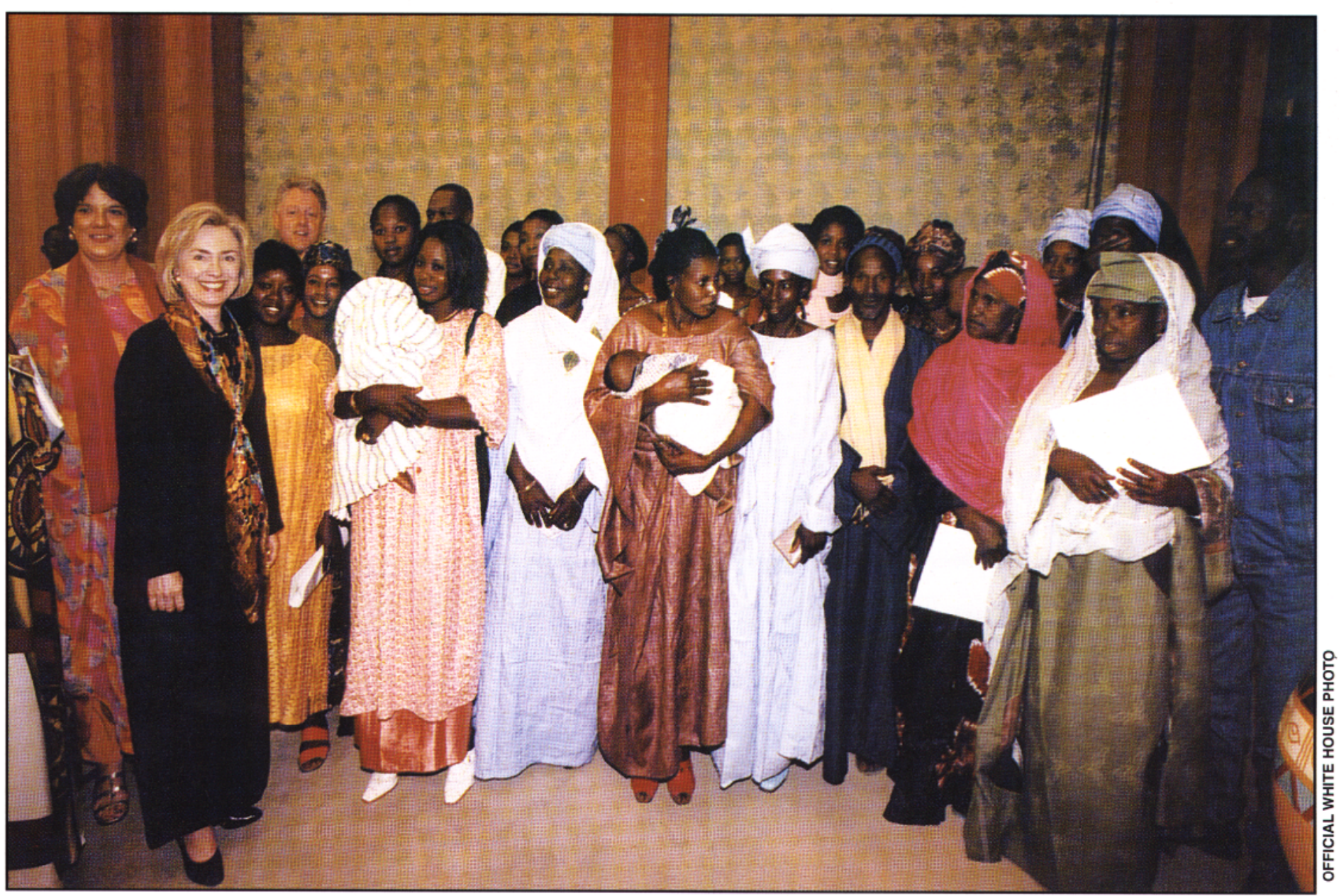

President and Mrs. Clinton congratulated the women and men who have struggled to end FGC during their visit to Senegal in April 1998. 
At a meeting of Melching with villagers from Samba Diallo on December 23, representatives from the neighboring town of Fimela attended the meeting. "We heard Demba Diawara and Tostan would be here today," said a young Bambara man, "and we want to know why we weren't included in the Diabougou Declaration. The Bambaras living in Fimela also want to stop FGC and were upset not to have been invited to participate in the Diabougou Declaration." Demba Diawara assured them they would be invited to participate in the upcoming seminar to be held in Baaliga during the month of March, 1999.

These villages have all requested the Tostan basic education program in their communities to gain further information and knowledge related to health and hygiene, as well as human rights, problem-solving and management skills.

\section{THE ST. LOUIS REGION - A CONSERVATIVE AREA RECONSIDERS FGC}

Tostan has implemented the basic education program in 70 villages in the departments of Podor and Matam since 1992. Both adult and adolescent programs have been highly successful in the area and have been greatly appreciated by the villagers over the years.

On July 27, 1998, Molly Melching made a trip to the region of St. Louis to visit both adolescent and adult classes, but also to discuss the issue of FGC with the Tostan trainers and facilitators in order to get their idea of the possibility of carrying out similar work on FGC in the St. Louis area with the Toucouleur ethnic groups. In conducting research on FGC, Melching had been greatly surprised to learn that many Toucouleurs practice infibulation in the same way as the Bambara, not by sewing but by sealing the cut lips together after the operation, using blood.

Melching writes of her trip:

"All of the Pulaar trainers and many facilitators were waiting for me the night of my arrival in Bokidjawe on July 27. During our discussions, I was warned by the trainers and facilitators that I should be very careful about approaching the subject of FGC in the Fouta. They felt the area was much more conservative than in the Thiès and Kolda regions. 'Don't worry,' I told them, 'I have not come to try to persuade people to join the movement. I have come to see our program and talk to the villagers and get their feedback on the new Community Based Schools we are opening. I also want feedback on the Continued Education Modules on Health and Democracy.'

"The trainers and facilitators were visibly relieved and explained that ending FGC in the St. Louis region would be a very long and slow process. They themselves seemed hesitant about formulating an opinion on the subject and I realized that they were afraid to even talk about it. I could see the worry and concern in their eyes.

"The next day we went off to visit the villages of Mew and Keddele, but unfortunately the road had been cut off by seasonal flooding and our car was not able to pass. We then were obliged to take a canoe to cross the river, and not finding public transportation on the other side, we hired a horse and cart to transport us to the village. The ride to Keddele took $11 / 2$ hours in the hot sun. Rain clouds threatened in the distance.

"When the people of the village saw me draped in my grand boubou and six 
other trainers and facilitators arriving on the cart, they could scarcely believe their eyes. The welcome was warm and appreciative for the efforts we had made.

"After eating together and resting a bit on mats laid out on the large adobe verandahs, the villagers called for everyone to gather round. The young women were seated on the left, the men on the right and the older women were sitting under the tree further ahead in front of me. I had been given a position of honor on a fine blanket spread on a mattress on the verandah. We spoke of many things: the adolescent program, the changes that had taken place in the village, the hopes of the women. Suddenly, a younger woman spoke boldly: 'Yes,' she said, 'We have even discussed the subject of the tradition which would never have happened before. We have learned of all the dangers linked to it and now know it is the origin of some of our own health problems. We women in fact would like to end the practice, but unfortunately our husbands, the men and the religious leaders would be opposed to our doing so.' No one spoke. It was obvious that the villagers were surprised that this women had dared to speak of the tradition during a public meeting. I myself was surprised, but tried not to show it. 'Well,' I said, 'Tostan has never tried to tell people to stop your tradition. The women of Malicounda made the decision themselves and we supported them in whatever way we could. But the decision has to come from you with the support of the community, I think. Then I turned to the men 'But tell me,' I said, 'what do you think about this? Do you feel the women should continue to practice the tradition if it is harmful to the health of girls and women?'

"The village chief answered 'The women have never asked our opinion before. Of course we would not oppose their ending a practice which had negative health consequences.' The women were stunned. Other men spoke in support of ending FGC. The Tostan trainers and facilitators spoke and for the first time voiced their opinion on the subject. Because the women themselves had voiced opposition, because the village men seemed open to a change and to supporting the women, the trainers and facilitators could finally speak their minds and speak with conviction!

"The ride from the village was long and we had barely made it back to the river, crossed in the canoe and then driven to the main road when the skies opened and the rain that had been threatening all afternoon poured down upon us as we rode safely back to Ourassougi. If the rain had come at any time earlier, we might have sunk in the field to the main road, or been swept down the river or stuck on the other bank. 'This is truly a sign,' proclaimed one Tostan facilitator. 'The fact that we were spared from the deluge must be a sign from God that we should really continue this work against FGC in the Fouta!' All the others nodded in assent, and I was quick to agree.

"As we visited other villages, the same message was heard over and over. 'We women would like to stop, but the men and the religious leaders would be opposed to our doing so.' It was clear that this idea was entrenched in their minds, but was not always true. In general, men do not discuss this subject at all with the women. It is rather assumed by the women that the men and religious leaders expect circumcision to be done.

"It became clearer now that the opinion of the religious leaders would be critical in the Fouta for ending FGC. For that reason, I made the decision to visit one of the most respected leaders in the St. Louis Region - Serigne Amadou Bah on July 30, 1998. I did not sleep the night before, for I knew that if the marabout spoke in 
opposition to ending the practice, there would be difficult times ahead.

"We arrived at the marabout's house at 8:30 AM and were led through a labyrinth of hallways to his room. Many of the Tostan trainers and facilitators accompanied me there and we spoke of many subjects related to the program, and also of the marabout's wife whom I know well. I was quite nervous and trembling when I finally told Serigne Bah the purpose of my visit. I told him that our work was related to improving the health of girls and women and told him the stories of the health workers in the Saint Louis region who have seen so much hemorrhaging and death. I told him that nonetheless, I deeply respected his opinion and that I needed to know his ideas on this before continuing our work on endingthe tradition. There was total silence in the room. The marabout's son said that it would be impossible for his father to answer that question right away. No one had ever asked him about it and it was a very delicate, sensitive subject. There was silence once again. Than came the deep clear voice of the marabout himself: 'No. I can answer the question. I can answer today. I have known your organization and UNICEF for many years and I have seen what you have done. Fighting for the health of children and women is a noble cause. You must continue this battle and not be discouraged.... because you will win. God is on your side. I will send my own son to work with you on this issue and will be available whenever you need me.' Not only had the marabout chosen to support our efforts to end FGC, he had done so with great conviction and even an offer of help. I could not hold back my tears.

"That same day we went to the village of Gollere. The women told me of their efforts to influence the others to end FGC by doing a theater before the villagers. 'Everyone seemed to like the play we presented on human rights,' one woman recalled, 'but we were booed and hissed when we did the play on FGC. Nonetheless, we will continue to try to change attitudes here on this subject.' I asked if 20 women could make a difference in a village of 3,000 people. Bani Bousso responded 'Where there are two determined women, it is already enough; where there are twenty determined women, there is great hope.' When I spoke of the support we had just received from the marabout in Tchikkite, the women were greatly cxcited, feeling they now had new and more powerful arguments for ending FGC. They were also working on the problem of early marriages in the village which they felt was just as important an issue".

After Melching's trip, Tostan and UNICEF sponsored a group for social mobilization in October, 1998 that went to 15 villages to hold public discussions in the Toucouleur communities where Tostan had implemented Modules 7 and 8. Lala Baldé, President of the Women's Group from Kolda volunteered to accompany three Tostan trainers and facilitators, the local health workers in the region and the son of the marabout from Tchikkité. The marabout's support once again made a tremendous difference in the way the group was received in these communities.

The health workers talked of the many problems they have encountered related to FGC. One nurse stated that he had recorded the deaths of five girls in 1997-98 who dicd from hemorrhaging or infection following the FGC operation. Many of the villagers expressed an interest in holding a seminar for the villages who have learned about the negative health effects of FGC and want to put an end to the practice through a communal action. All of the 70 villages who have been through the 
Tostan program will be invited to attend and discuss the issue together. Once again, there will be no pressure to make a public declaration if the villagers are not ready. Many villages have, however, expressed their desire to end the practice when everyone is assembled.

\section{LASTING PLEDGES?}

During the Malicounda pledge, one newspaper reporter asked if the women would stick to their decision to end FGC. Everyone was perplexed at this question. "Why make a declaration if you are not going to go through with your decision?" they responded.

"It's a question of honor," said one older woman in Mampatim in the Kolda region, "And besides why in the world would we go back on that decision now? My ancestors spent much of their time drinking palm wine and now no one would ever dream of consuming alcohol in this village! Change is not that difficult when it's in your best interest!"

In the villages participating in the Diabougou Declaration, a committee was elected to monitor the seminar follow-through, assuring that no participating village organized the FGC rites. Demba Diawara explained that if one person is allowed to get by with practicing FGC on their daughter, it will damage the whole movement to end the tradition. "We would have to take the case before the law to set an example," he said. "If we did nothing, people would think the decision was not serious and they might start slipping back into the practice out of fear of not finding marriage partners for their daughters."

In Medina Cherif the men said they have been checking on the cutters of the zone to assure they are no longer practicing their traditional job. "We can certify that they have stopped since the Declaration," one of the men told Tostan. The women also told us of a village that had initially declined to participate in the Medina Cherif Declaration and have now changed their minds. "When they performed their Circumcision rites this year, one of the young girls of the village died from a hemorrhage!"' Lala Baldé noted sadly. "It was just like the play we had performed to try to get them to stop. Now they understand that the death was from the cutting and not because of spirits. The whole village has decided to end FGC. We do not have people who are slipping back, we have people who are joining our movement."

When asked if they missed the dancing and songs of the initiation rite, one older woman replied: "The dancing and songs are nice, but when you are holding a dead child in your arms, what do those songs and dances mean then?"

Altogether 31 villages in Senegal have officially and publicly declared an end to FGC and have continued to respect and defend their decision. Ten other Bambara villages have requested a seminar to declare an end to FGC together as a community in March 1999. Many villages in the departments of Matam and Podor of the St. Louis region are preparing for their seminar to discuss FGC. The pledges are lasting and spreading. 


\section{THE LAW AND FEMALE GENITAL CUTTING}

On January 6, 1999, a parliamentarian in the Senegalese National Assembly and President of a Parliamentary Group, Abdou Fall, sought the advice of Molly Melching and Bilal Ndiaye of Tostan concerning the upcoming law to be debated by the National Assembly on Female Genital Cutting. Given the positive experience Tostan has had with villages abandoning FGC, he was eager to hear Tostan's opinion.

The official proposal for modifying certain dispositions of the penal code gives the following rationale for penalizing Female Genital Cutting:

"Female genital mutilations, although part of traditional practices and customs, constitute intolerable violations of the physical and psychological integrity as well as of the health of many women and young girls. These practices are no longer relevant in the new socio-cultural dynamic of Senegal. Their legal abolition as indicated in the new article 299 of the penal code takes this into account and also the respect of international conventions ratified by Senegal, especially the Convention of 1979 on the Elimination of all Forms of Discrimination Towards Women and the Convention of 1990 regarding Children's Rights."

The pending law itself states:

"Six months to five years of imprisonment is the punishment for anyone having violated or attempting to violate the physical integrity of the genital organs of a person of the female sex by total or partial cutting of one or many of its elements, by infibulation, by making them less sensitive, or by any other means.

The maximum penalty will be applied when these sexual mutilations will have been carried out or favored by a person from the medical or paramedical corps.

When these acts lead to death, the penalty of forced labor for life will be pronounced.

Any person who through contributions, promises, influence, threats, intimidation, or abuse of authority or power has provoked these sexual mutilations or given instructions for them to be committed will be punished with the same sentence."

Article 299 bis

The vote was scheduled for January 13, 1999. Melching suggested to Mr. Fall that he visit the communities who had decided to abandon Female Genital Cutting during the weekend to discuss the issue directly with the people concerned. It also seemed appropriate to bring a delegation of these villagers to speak with a larger number of parliamentarians before the vote on Wednesday, January 13. UNICEF received an official letter from the President of the Commission on Health and Social Affairs of the National Assembly asking for their assistance in bringing these representatives to Dakar for a meeting on January 12, 1999.

During Mr. Fall's visit to the villages of Malicounda, Nguerigne Bambara and Diabougou, he was surprised to learn that the problem of Female Genital Cutting was considerably more serious than he had originally imagined. During discussions with the women, men and children, Mr. Fall discovered that much of the women's suffering had been hidden from the men. Now that the truth had begun to emerge, the picture was grim. Women spoke of suffering, problems at childbirth, hemorrhaging and death. Nonetheless, the villagers emphasized that they stopped only because of the 
education program and public discussion of the issue.

Mr. Fall realized that a strategy for education and social mobilization before application of the law would be needed to avoid serious conflict over the issue in the country. One Bambara man in Diabougou explained to him: "We Bambaras are hard-headed. If we learn something and decide it is right we will follow through on this decision forever. But if something is forced upon us from the outside, we will pick up our knives to fight without hesitating!" After this trip, Mr. Fall decided he would vote for the law since the State must protect the health of girls and women, but realized it was extremely important to emphasize education and social mobilization during the debatc. Would it not be better, in fact, to delay the application of the law to allow time for social mobilization strategies and education of villagers?

On January 12, 1999 a delegation of 13 villagers from Malicounda Bambara, Keur Simbara, Nguerigne Bambara and Medina Cherif, including women, men and one girl, child, met with members of Parliament representing different Senegalese political parties. Mata Sy Diallo, Vice President of the women's Parliamentary Network and President of the Commission for Health and Social Affairs presided the meeting. Other women's groups who have fought for many years for a law to abolish FGC were present.

The message of the villagers to the parliamentarians was clear:

-FGC is a dangerous practice that has caused much suffering among women and children.

-Women have hidden the extent of this suffering over the years and many are still not aware of the health risks involved.

-Islam does not oblige Female Genital Cutting.

-A tradition which harms and kills is not a good tradition.

-Everyone should stop practicing FGC.

-Repression is not the means to stop people from practicing FGC.

-We were able to stop because of knowledge learned through the Tostan basic education program.

The villagers expressed their concern for other members of their ethnic group who have not benefited from basic education and do not know about the risks involved with Female Genital Cutting. They felt it was important for the government to take a firm stand against the practice by voting the law, but they unanimously requested a delay in the application of the law.

In a technical meeting following this encounter, members of the Commission of Health and Social Affairs referred to the opinions of the villagers and decided to request an amendment to the law to provide for a delay in its application.

On January 13 at 4:30 PM the debate began on the amendment in the National Assembly. Mata Sy Diallo of the women's parliamentary group began the debate and spoke of the dangers of FGC. She thanked the villagers who testified before her committee on January 12 and spoke of their desire to see accompanying measures that should be inacted to assure sufficient education before application of the law. Many other parliamentarians spoke of the health dangers of FGC and the need to end the tradition. They were all worried however, about the reaction of villagers who have not been through an educational process. Many cited Malicounda Bambara as a successful example which could be replicated in order to enlighten people on the need to end the tradition. Several parliamentarians said that they could not vote for the law becaus. 
they did not want to criminalize their relatives for respecting tradition and religion.

That same day, an influential Senegalese religious leader had distributed a paper on Female Genital Cutting stating that the practice was required by Islam. Many parliamentarians seemed worried about this document and raised questions about circumcision and religion during the debate. Unfortunately, statements by other influential religious leaders explaining that FGC is not an obligation in Islam had not been distributed to the parliamentarians or to the press before the debate.

It was quite apparent during the session in Parliament that all of the women, most who were from ethnic groups which practice FGC, were the greatest defenders of the law and extremely critical of the practice, whereas the men were more hesitant.

The Minister of Justice refused to allow for a delay in the application of the law stating that it was useless to vote a law that would not be applied immediately.

At 11:20 PM, on January 13, 1999, the National Assembly passed the law, as submitted, to abolish Female Genital Cutting in Senegal forever. 


\section{A SUMMARY OF EVENTS}

\begin{tabular}{|c|c|}
\hline January, 1995 & $\begin{array}{l}\text { Opening of the Tostan non-formal education } \\
\text { program in Malicounda Bambara in collaboration } \\
\text { with UNICEF and the Government of Senegal }\end{array}$ \\
\hline July-August, 1996 & $\begin{array}{l}\text { Tostan Module } 7 \text { - Women's Health module } \\
\text { implemented in Malicounda Bambara, funded by } \\
\text { AJWS }\end{array}$ \\
\hline September, 1996 & $\begin{array}{l}\text { The women of the class of Malicounda Bambara } \\
\text { decide to end FGC }\end{array}$ \\
\hline $\begin{array}{l}\text { October, } 96- \\
\text { May, } 97\end{array}$ & $\begin{array}{l}\text { Malicounda women lead a campaign in the village } \\
\text { with their husbands, the religious lcaders, other } \\
\text { women, and the village chief to end FGC }\end{array}$ \\
\hline June, 1997 & $\begin{array}{l}\text { The Tostan coordinator evaluates the program } \\
\text { and finds that no circumcision ceremonies were } \\
\text { performed in Malicounda Bambara that year }\end{array}$ \\
\hline July, 1997 & $\begin{array}{l}\text { Molly Melching and Bilal Ndiaye from Tostan visit } \\
\text { the village and interview the women, Imam and village chief }\end{array}$ \\
\hline July 31,1997 & $\begin{array}{l}20 \text { Senegalese journalists visit Malicounda Bambara where } \\
\text { the women declare an end to Female Genital Cutting }\end{array}$ \\
\hline August, 1997 & $\begin{array}{l}\text { A national debate on FGC unfolds in newspapers, on the } \\
\text { radio and television }\end{array}$ \\
\hline August, 1997 & $\begin{array}{l}\text { The women of Malicounda visit Keur Simbara to } \\
\text { discuss ending FGC }\end{array}$ \\
\hline September, 1997 & $\begin{array}{l}\text { The men of Malicounda are uncomfortable with } \\
\text { publicity from the women's decision }\end{array}$ \\
\hline September, 1997 & $\begin{array}{l}\text { Journalist Roland-Pierre Paringaux from Le Monde spends a } \\
\text { week in the villages with Molly Melching researching the } \\
\text { event }\end{array}$ \\
\hline October 14,1997 & $\begin{array}{l}\text { One page article appears in Le Monde on the } \\
\text { pledge of the women of Malicounda }\end{array}$ \\
\hline November 6, 1997 & $\begin{array}{l}\text { Women of Nguerigne Bambara make a public declaration to } \\
\text { stop FGC with support from the entire community }\end{array}$ \\
\hline November 22,1997 & $\begin{array}{l}\text { The President of Senegal, Abdou Diouf, states his } \\
\text { position against FGC at the International League of Human } \\
\text { Rights supporting the Malicounda women (and citing the } \\
\text { article in Le Monde) }\end{array}$ \\
\hline $\begin{array}{l}\text { November } \\
\text { December, } 1997 \text { - } \\
\text { January, } 1998\end{array}$ & $\begin{array}{l}\text { Chiekh Traoré (Tostan facilitator) and Demba } \\
\text { Diawara (Tostan participant and Imam of Keur } \\
\text { Simbara) visit } 10 \text { villages near Joal to discuss ending FGC } \\
\text { with their extended family }\end{array}$ \\
\hline February 3, 1998 & $\begin{array}{l}\text { President Abdou Diouf calls for a law to abolish FGC in } \\
\text { Senegal at his Council of Ministers }\end{array}$ \\
\hline
\end{tabular}




\begin{tabular}{|c|c|}
\hline February $14-15$, & $\begin{array}{l}11 \text { villages from the Bambara ethnic group decide } 1998 \\
\text { to support Malicounda and Nguerigne Bambara in their } \\
\text { decision to end FGC. } 50 \text { representatives of } \\
8,000 \text { villagers write and announce the Diabougou Declaration }\end{array}$ \\
\hline $\begin{array}{l}\text { February - April, } \\
1998\end{array}$ & $\begin{array}{l}14 \text { villages in the region of Kolda study Tostan } \\
\text { Module } 8 \text { on Early Childhood Development including } \\
\text { sessions on FGC }\end{array}$ \\
\hline May, 1998 & $\begin{array}{l}\text { Medina Cherif makes a community decision to end FGC } \\
\text { followed by } 13 \text { other nearby villages participating in the } \\
\text { Tostan program }\end{array}$ \\
\hline June $1-2,1998$ & $\begin{array}{l}4 \text { more villages join and } 18 \text { villages from Kolda } \\
\text { Department (where } 88 \% \text { of the population practice FGC) } \\
\text { publicly declare an end to FGC }\end{array}$ \\
\hline July, 1998 & $\begin{array}{l}\text { Molly Melching visits the St. Louis region of Senegal } \\
\text { where Tostan has implemented the program in } 70 \text { villages. } \\
\text {-Certain villages express their desire to end FGC } \\
\text { - Tostan receives support and blessings from the marabout of } \\
\text { Tchikkité }\end{array}$ \\
\hline October, 1998 & $\begin{array}{l}\text { A team of Tostan facilitators and trainers from the North, } \\
\text { Lala Baldé from Kolda, the Marabout's son and local health } \\
\text { workers visit } 15 \text { villages in the St. Louis Region to } \\
\text { discuss FGC }\end{array}$ \\
\hline $\begin{array}{l}\text { September- } \\
\text { November } 1998\end{array}$ & $\begin{array}{l}\text { Demba Diawara visits other Bambara villages to discuss } \\
\text { ending FGC } \\
\text {-Receives support to end FGC from influential Bambara } \\
\text { religious leader } \\
\text {-10 other villages express desire to end FGC in solidarity } \\
\text { with other Bambara villages through a public declaration }\end{array}$ \\
\hline December, 1998 & The Council of Ministers approves a law to abolish FGC \\
\hline January 12,1999 & $\begin{array}{l}13 \text { members of the Bambara, Mandinka and Pulaar } \\
\text { communities meet with members of Parliament }\end{array}$ \\
\hline January 13,1999 & Law voted by the Parliament to abolish FGC \\
\hline
\end{tabular}




\section{PART III}

\section{Reflecting on the}

experience

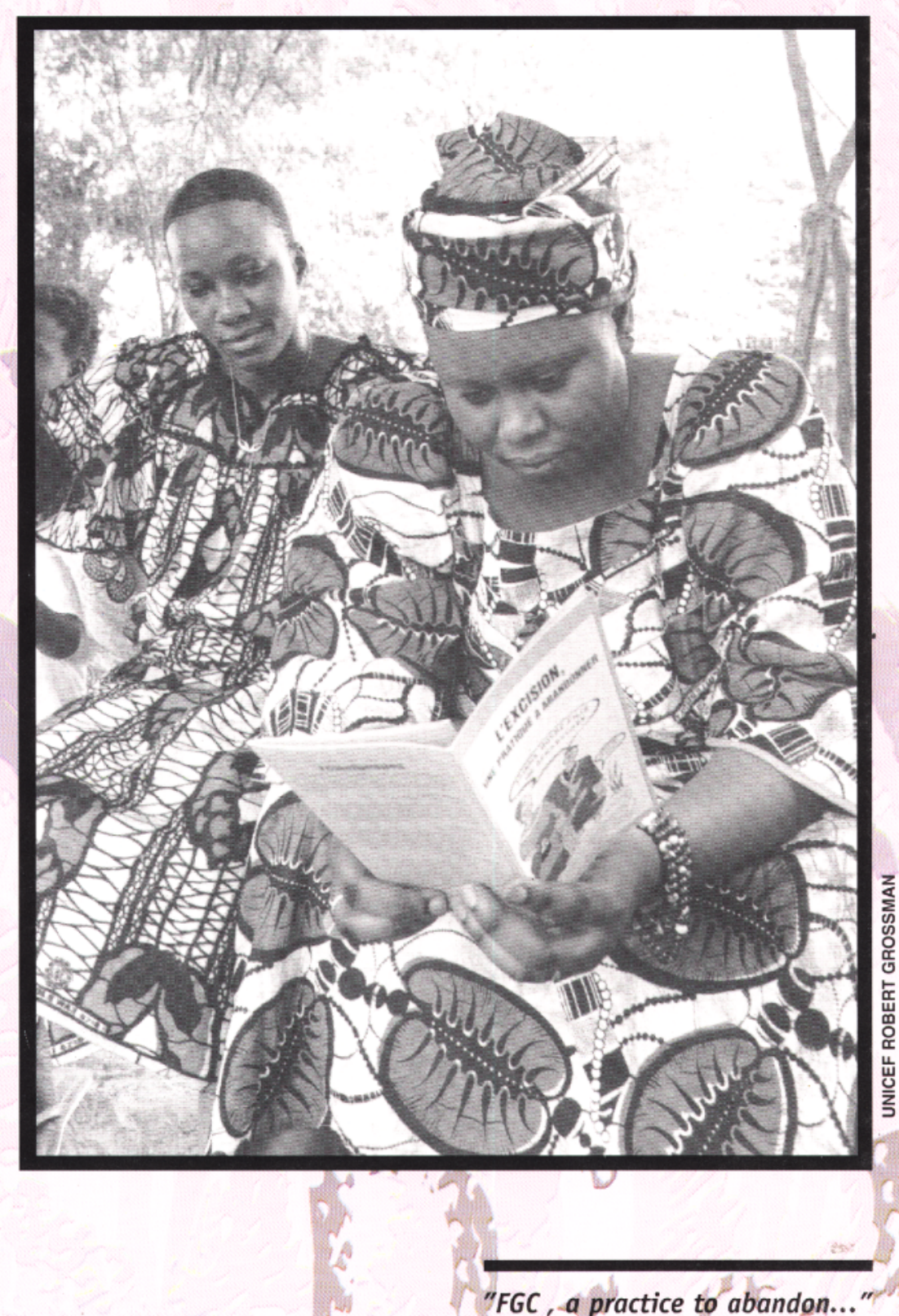




\section{ELEMENTS OF THE TOSTAN EDUCATION PROGRAM CONTRIBUTING TO THE END OF FGC IN SENEGALESE VILLAGES}

In the process of ending Female Genital Cutting, basic education was without doubt the decisive factor in the movement that led to the villages publicly declaring an end to this ancient practice. The technical information, the strategies for social transformation as well as the confidence and self-determination the women gained through the participatory methods of the Tostan program were all essential elements which contributed to their positive achievements in 1997-98.

\section{MODULES 1 THROUGH 6: AN IMPORTANT BASE OF TECHNICAL INFORMATION}

The women and men most involved in the process of ending Female Genital Cutting pointed out specific information they learned in the Tostan modules that was useful in making their decision to end the practice.

\section{Problem-Solving}

In the process of working on collective problem-solving in Module 1, the participants learned to work together to achieve a common goal. The women of Malicounda and Nguerigne Bambara often made reference to this process as being a help in organizing their ideas and activities. In Malicounda, they had already used the process to carry out village hygiene activities, to solve problems with their village facilitator (during Module 3) and to create a soap-making project for the class. As they were planning social mobilization activities on FGC in their village, the women tried to envision possible problems (Step 3 - Planning the Solution - Obstacles). Foreseeing these obstacles helped them to avoid certain problems and prepared them to respond with confidence when difficulties arose. The rehearsal through role-play or theater uscd in class sessions helped participants reflect on the best ways to present new ideas or decisions. They were also prepared to respond to arguments or opposition to their ideas.

The first step of the problem-solving process, problem analysis, helped women gain insight into the importance of cause and effect. In regards to Female Genital Cutling, they had always believed that "bad spirits" were the cause of any health problems observed with their girls. Learning, for example, that infection after circumcision was related to other causes was a surprise for the women but one they were capable of understanding because of their knowledge of the transmission of germs, learned in Module 2. 


\section{Hygiene: The Transmission of Germs: an essential notion}

In one activity of Module 2, a bowl of water in which perfume is added by the facilitator is passed around the class and each woman is asked to rinse her hands in the bowl. Although the participants admit that they don't see anything, they nonetheless know there is something else in the bowl because they then smell the perfume on their hands. This something is like germs - invisible. Women often made the analogy to this class experiment when discussing how one razor blade used on many girls can transmit germs to the other girls who are cut with the same blade.

In one Bambara village the religious leader was opposed to the women ending the practice of FGC and made a statement about how FGC could not be the cause of certain infections and illnesses such as AIDS as had been insinuated by health workers. One woman who had been through the Tostan program and was sitting next to Melching whispered: "If he had studied Module 2 he would understand that 'the tradition' doesn't lead to the infection; it's the transmission of germs from a non sterile razor blade from one girl to another which CAN lead to infection!"

Germ transmission and the need for hygiene was also emphasized throughout Module 3 concerning diarrhea and vaccinations.

\section{Leadership skills help in making and defending important decisions}

The leadership sessions in Module 5 helped to reinforce leadership skills among the women and provided the opportunity to discuss the decision-making process and characteristics of good leaders within the nurturing space of the classroom. When the women stood up to defend their decision to end FGC, their confidence, determination and leadership skills were evident to all present.

\section{MODULES 7 AND 8: THE TURNING POINT}

The modules containing the most information which helped the women in making their decision to end FGC were Modules 7 and 8.

Health information makes a difference

Learning about their bodies, particularly the reproductive organs and the importance and inter-dependence of all the body systems and functions was important in helping the women to better understand the dangers linked to genital cutting. Many of the women did not realize that other women in the world are not circumcised and if they were aware of this, did not know exactly what that meant. Many had no idea what normal female organs looked like and were seeing pictures and diagrams for the first time in their lives.

\section{Discussing sexuality}

Tostan also believes that the session on sexuality played a role in the women's decision to end FGC. This session turned out to be one of the most popular of the module in all villages, whether they practiced FGC or not. The content helped women to understand, through discussion, that women indeed have the right to a healthy sexual life. Once again, role-play was used to help the women practice discussing this sensitive issue with their husbands. In evaluation after evaluation, the women noted 
that because of Session 7 of the Module, they found ways to approach their husbands for the first time concerning their sexual needs. The session never mentions circumcised women specifically. However, the women who had undergone this operation must have realized that their sexual satisfaction may be less than for other women. "When women realize that they are not able to have the same type of sexual pleasure as other women such as the Wolof who have not been circumcised, they wonder if this is not the reason that their husbands take second and third wives, often among that ethnic group," a Mandinka radio journalist commented.

\section{Learning and experimenting with strategies for social transformation}

Strategies for bringing about social transformation through organizing women's support groups and working with traditional, religious and local administrative leaders is also emphasized in many of the sessions of Modules 7 and 8 . Peace is a key concept in Senegalese society; therefore, it was extremely important to encourage peaceful methods of change in the village. The women felt comfortable using these strategies because it allowed them to involve the important opinion leaders of the community in their activities in a respectful way. Many found that the men and religious leaders were more supportive and progressive than they had imagined. In fact, the men were extremely pleased to be included in these discussions and felt the women were taking their viewpoints into consideration. Thus the men became more open to change. This process led to new dialogue and consensus around other important issues of the community, not only FGC.

\section{Adopting a friend, sharing knowledge}

For the sessions of Modules 7 and 8, Tostan asked the women to adopt a sister or friend ("ndey-dikke" in wolof) with whom they would share the information learned during the module each day. This system proved to be highly effective for several reasons:

- the women were motivated to write down summaries of what they learned in class, thus reinforcing their reading and writing skills as well as their own understanding of the topics;

- the experience was an empowering one for the women. In evaluations they stated that their "ndey dikke" showed them great respect because of their new knowledge;

- many women chose to share their information with more than just one woman, organizing small groups in the neighborhood. In the St. Louis region, the women also said they adopted their husbands and the village religious leaders as well as a friend.

- the practice the women received in teaching the new information gave them confidence in sharing the information on a larger scale. Many participants developed themes from Module 7 at their larger women's group meetings or held public sessions for the entire village.

\section{Linking knowledge to action}

Another new element of Modules 7 and 8 was the effort of the Tostan conception team to include an action objective for each theme and sometimes each session. Thus, this module became more action-oriented and the results were immediately observable in the many participating villages. 


\section{Human Rights Education}

The Human Rights Education begun in Module 7 also was a powerful contributing factor in the decision to end FGC in the villages. Tostan began doing human rights education after the extensive participatory research with hundreds of women in developing Module 7 in 1994. The results of that research indicated that the women's problems related to the family, health, education, the environment, law, and the economy were often due to a lack of knowledge of their rights and responsibilities as well as of those of the community. This lack of knowledge also compromised their participation in public life. Tostan then decided not only to inform the village women of their rights and responsibilities, but also to help them appropriate these rights. We did this by using their own stories and experiences, then providing a nurturing space to find solutions and help achieve desired change based on the social, cultural and economic environment in which they live.

Tostan believes that experience with this active human rights education has led to rapid and positive social transformation not only in the area of ending Female Genital Cutting, but also in other areas. For example, after studying Module 8 on Early Childhood Development which uses universal children's rights as a reference in all sessions, the women of Touba Toul recognized they were violating their children's rights by sending their 10-12 year old girls to work as maids in neighboring towns: children's rights to live with their parents, to education, to love and affection, to be spared from unsuitable work or to not be exploited by others and finally the right to play. The class decided to use strategics discussed in the module to change the situation. The President of the Women's Group called for meetings in the different neighborhoods of the village. There the women presented a play and poems on children's rights and the negative consequences of sending children off as maids at such a young age. These were used to provoke comments and encourage debate with other villagers. They then discussed the human rights abuses involved in this practice. They made reference to specific articles violated to make more of an impact. In March, 1998 they organized a special day of consciousness-raising on sending children to work as maids, inviting village leaders and local government authorities to attend and speak out on the practice. A communal decision was made that day to stop sending young girls off as maids and a committee was elected to discourage abuses.

It is important to mention this other experience to show that the Malicounda Pledge and the Diabougou and Medina Cherif Declarations were part of a broader movement for social justice. This example demonstrates the impact an entire village can make when the members of the community fully participate in the decisions which affect their lives and that of their children; when they have the skills, confidence and courage to envision and develop strategies for positive and peaceful social transformation in respect of human rights norms, taking into account their own socio-cultural environment. 


\section{THE ROLE OF DIALOGUE IN THE CLASSROOM: DEMYSTIFYING NGIR-NGIRO}

\section{FGC and the reign of silence}

In 1995, Molly Melching presented the session on Female Genital Cutting for Module 7 to the Bambara women of Kër Simbara. She explained she had come to ask their opinion on the session, knowing that they were of an ethnic group that generally practices FGC. The women, who were usually open, enthusiastic, and quite talkative, were suddenly silent. There was a tenseness in the air that she had never before encountered in that village. Asked why they did not want to discuss this issue, they replied that it is an ancient tradition. There had never been any problems associated with 'the tradition' in their village, so why discuss it?

Melching was perplexed. It was obvious that there was something deeper going on. Why were the women so hesitant to talk about Female Circumcision? She knew these women well and had always been able to exchange ideas freely with them, yet suddenly they were irritated and evasive. There was more than just an attitude of reluctance,....there was a certain fear in their eyes which she didn't understand. So she asked them if it weren't better to throw out the session since it obviously bothered them. "No" they said with much emphasis, "Do NOT eliminate the session." But they wouldn't explain why they wanted to maintain it either. She was confused but decided to maintain the session on Female Genital Cutting. Melching was later told by a village elder that she was lucky not to have been banished forever from this village for having even brought up the subject of FGC.

Female Genital Cutting was truly a taboo subject in Senegal. Any efforts to bring up the subject and discuss it, let alone to suggest an end to it were unimaginable in many regions of the country. Health education agents and development workers had tried various approaches in getting people to end this harmful practice but with few results. The percentage of people practicing FGC has not decreased substantially in any of the African countries where it is practiced. One reason is that the people who practice FGC simply refuse to discuss it at all.

Melching initially thought this silence was similar to women's silence in all countries of the world concerning taboo issues, such as violence against women or incest. She eventually learned, however, that the reason for the silence went even deeper and was closely related to traditional education and key elements of the initiation rites.

\section{The cultural significance of initiation rites}

Many ethnic groups no longer practice initiation rites for the girls who undergo Female Genital Cutting. Indeed, the villagers participating in the Diabougou Declaration indicated that the actual cutting now takes place when a baby girl is only 2 or 3 months old, making any type of initiation impossible. Nonetheless, most of the women who now have this operation performed on their daughters have themselves gone through some type of educational process or initiation rite when they were circumcised. The teachings from these rites remain with the women and are often passed on to their daughters informally.

According to Daouda Ndiaye, a traditional Mandinka healer and Master "Juju' 
(juju is the area where the initiation takes place), initiation is a crucial time in the life of the African girl. It is the moment where she "passes" from being an immature girl to the state of being a real women. According to Mr. Ndiaye, initiation involves 3 inter-related aspects:

1) an educational aspect where the girl learns her place in society and her role as woman, wife and mother;

2) a physical aspect during which the girl must undergo physical pain to prove she is capable of assuming this new role courageously showing no signs of suffering and pain. This comes through the actual cutting but can also be through punishments received by the girls in complete submission throughout the weeks of initiation.

3) a solemn pledge to silence pertaining to anything the initiated has undergone or witnessed during the initiation ceremony.

\section{1) The educational and psychological aspect of initiation}

During the psychological and educational initiation into womanhood, the girls are taught essentials related to being successful in life and fulfilling their role as women in society. One of the legends the girls might be told during initiation is the story of how the Great Spirit came down to speak with the first man and woman on earth. He turned to the woman and asked her what she most desired from life.

"I want to be the master, the creator in this world," she declared.

"So be it", replied the Great Spirit. "You will be the master, the creator in this world, but you must be willing to pay for the important role you will play. You will know suffering and you do not have the right to complain, for this is the role you have chosen. Complaining will lead to ill fortune for you and your children."

The woman then regretted this choice but it was too late.

The Great Spirit turned to the man: "What is your desire?"

"I would have been master and creator in this world, but since the woman has already chosen this role, I wish to be master of woman."

"So be it." the Great Spirit told him "you will be master of the woman but only if the woman consents."

According to the myth, this is why women give birth and create all the great leaders of this world. It is also why they suffer and do not have the right to complain about their pain. It is a sacrifice for humanity. They must also always obey their fathers and their husbands, who are their masters. To do otherwise would bring ill fortune upon their families. (Story recounted by Daouda Ndiaye)

Initiation prepares the girl for her role of wife and mother: she learns she must be patient, polite, obedient, calm, respectful, ready to serve and help others in need. She should not talk too much, and never about family affairs, she must show honor to her parents and relatives, love her husband and adore her children. The girls are taught signs of respect shown to elders and to men: never looking someone in the eyes when speaking, kneeling when greeting or bringing water, speaking softly and not talking or laughing too much. Many secret gestures are learned for silent communication between men and women and between two initiated women.

A woman learns that when she is totally initiated, she will be fertile and all bad things will be barred from her path. The spirits of ill fortune will be unable to penetrate her protective curtain of politeness and respect. 
She will know how to tolerate other behaviors and manage difficult situations. The initiation the girl receives follows her throughout life and forges her place in society.

\section{2) The physical suffering aspect of initiation}

During the physical trials of initiation, girls must prove that they are ready to face the difficulties of adulthood. They are cut and must not cry out or show any signs of pain or suffering. They are punished when they do not react properly. It is believed that if girls can endure the pain of initiation, they will be able to confront any form of suffering which they might encounter during their lives. Thus, the passage rites become a preparation for the hardships of real life and are considered essential tools for building strong character in women.

Many women talk of how the cutter threatened them and whispered to them not to cry out when cut or they would bring terrible dishonor on their family.

\section{3) The solemn pledge - swearing to never speak of the initiation experience}

Another important aspect of the initiation rite is the solemn pledge never to divulge secrets of initiation. It is particularly prohibited to speak of any pain or suffering during the initiation period. Anyone who stands up against this taboo takes great risks:

"In the Mandinka ethnic group, Ngir-Ngiro is the 'rab', the spirit which attacks women who dare to break the silence and speak of any suffering or negative effects related to their experience with Female Circumcision. In fact, women are told to live what they have learned but never to discuss it, the consequences being quite serious: for example, mental illness, paralysis, or even death. This is why women never dare to speak about Female Circumcision, especially to someone who is not initiated," says Daouda Ndiaye.

Ngir-Ngiro does not always exist under that name in other ethnic groups, but what Ngir-Ngiro represents does. Learning about this Mandinka spirit and the importance of remaining silent about this tradition helped us to understand many experiences over the past two years such as:

- the women refusing to talk about FGC in class and in public

- the fear in the women's eyes when asked to speak, particularly around someone from another ethnic group or a foreigner

- the Malicounda men's reluctance to discuss the issue publicly

- the strong reaction when outsiders become involved in criticizing FGC

- the different warnings of Demba Diawara who was constantly talking about his "secrets" for talking with other Bambaras.

After learning about Ngir-Ngiro, Melching had a meeting with Demba Diawara. "Demba, do you know about Ngir-Ngiro, the spirit which attacks people if they talk about their initiation secrets?"

Demba smiled. "Now you understand what I was talking about. This is why it has been so difficult for me to go into new villages! People are worried about bringing bad fortune on themselves or their families by talking about initiation. You just don't do it. This is such a deep belief among the people of my ethnic group that it is difficult to break down the barriers." 


\section{FGC and the reign of silence: Tostan and the use of dialogue in the basic education program}

Perhaps the most important contribution of the Tostan basic education program to ending FGC in Senegalese villages, were the methods developed by the program which allowed the women to discuss this normally taboo issue in a non-threatening environment.

In Senegal, it would seem that dialogue would be a natural aspect of an educational situation since Senegal is a country known for dialogue and conversational exchange. According to a well-known Wolof proverb: "Xuloo amul, ñaq waxtaan moo am." (Fighting doesn't exist, only a lack of discussion exists). Unfortunately, the dialogue and exchange of ideas that occurs naturally in Senegalese society in the market place, in the home, or under the village baobab, almost never exists within the formal classroom situation.

The French educational system and Islamic religious education have both so influenced Senegalese society that the idea of education and learning is now associated with a "master" who teaches and inculcates knowledge to learners who have the passive role of memorizing, often without the possibility of questioning information received from the teacher. Over the many years that the Tostan program was developed, the most difficult pedagogical notion for trainees to comprehend and use was the right of the student, whom we called "participant", to indeed "participate!" to speak up, to have a different viewpoint than the teacher, whom we called the "facilitator". Most facilitators who had received a formal education felt they were not good teachers if they did not provide lengthy lectures. Not only were they worried about what the students' perception of them would be if they didn't act as most other teachers in the country, they were also worried about being judged negatively by outsiders coming to visit the class.

Tostan worked with trainers, facilitators and participants to help them discover that the participatory form of education is in fact African in origin. Sitting in a circle (as one does in a traditional African village in the village square); allowing each person to express one's idea (as happens in a village meeting); listening carefully and patiently to other's ideas (as is taught in traditional African education); coming to consensus through negotiation and mediation (well-known African skills) making use of the oral tradition; learning by observing and doing oneself (as is the method for traditional learning of jobs such as blacksmith, shoemaker, or hair braiding) are all methods that were reinforced and used in the Tostan training.

The Tostan conception team also strove to write sessions in such a way as to provoke discussion among participants and to train facilitators capable of allowing class participants to work out issues among themselves in small groups or in the larger group.

The practice gained in the classroom transferred to real life situations and the women began to participate more and more in village meetings, often speaking their minds for the first time publicly. Exchanging experiences also led to opening up to one another and gaining confidence in the other women of the class. This was essential in the process of ending FGC in participating villages.

On many occasions the women of the villages were asked how they would replace the initiation rites. Their answer is significant: "The Tostan class will replace 
our initiation rites." is often the answer. "The members of the class are now like the women with whom we went through initiation. We have shared ideas, experiences and secrets as we learn in the classroom and we now have a common bond based on mutual trust. We have also seen how our lives improve when we work together for the same goal."

When Demba Diawara goes from village to village, he proposes that certain traditional beliefs in spirits are not consistent with the teachings of the Koran and thus should be forgotten. He also suggests that the education class can give the women new strength and confidence in facing the challenges of the future. Such arguments convinced the populations of 21 other villages to declare an end to FGC. 


\section{OTHER FACTORS CONTRIBUTING TO THE END OF FGC IN SENEGALESE VILLAGES}

\section{THE TIME WAS RIGHT}

For many years, women's groups and organizations working to improve women's health in Senegal had advocated an end to Female Genital Cutting. At seminars, public conferences and at government health workshops and trainings, more and more doctors and influential Senegalese leaders were speaking out on the harmful effects of FGC. Non-Governmental Organizations such as ENDA, The Population Council, PATH and COSEPRAT (The Senegalese Committee to End Harmful Negative Traditions), as well as international organizations including UNIFEM, UNICEF, FNUAP, and WHO had all been working on strategies that would help to eliminate the practice. Conferences using traditional and religious leaders were often broadcast on the radio.

As would be expected in the beginning of such a campaign, there was much resistance on the part of the rural populations practicing FGC.

The traditional mid-wife in Malicounda Bambara recalls: "About five years ago, I came back from a government sponsored health training program in which we were taught to dissuade people from practicing Female Circumcision. When I tried to talk to the women of Malicounda about this, they all just laughed in my face and said to be quiet about our 'tradition'. I never brought it up again." Maïmuna Traoré also told of a meeting where the Presidents of Women's Groups were asked to encourage the women in their groups to stop practicing Female Circumcision in 1994. "At that time," she states, "I was quite opposed to ending the practice and said so openly at the meeting." Nonetheless, the women of Malicounda Bambara were aware of a growing opposition to the practice in the country.

Demba Diawara noted "If this had happened five years ago, people would have been in serious trouble for bringing up such a subject." The difference was that times had changed and the villagers had been hearing radio reports in national languages about the health risks of FGC. "We have even heard that the subject is now being debated in Mali!" one villager exclaimed.

\section{THE POSITIVE PARTICIPATION OF ISLAMIC LEADERS}

In a country where $95 \%$ of the population is of the Muslim religion, where religion plays a major role in the everyday lives of the majority of the population, it is evident that the opinion of Senegalese religious leaders would play a decisive role in the growing movement of Senegalese communities to end Female Genital Cutting.

Despite the fact that several religious leaders had spoken out against the practice in recent years in public conferences or seminars in Senegal (mostly in urban centers), the village women had a general misconception that both their local and 
national religious leaders supported the practice of Female Genilal Cutting. Indeed, the majority of the village women believed that FGC was an Islamic practice sanctioned by the Prophet and therefore one that could not be questioned. Some believed it was an obligation written in the Koran, others believed it was a recommendation and therefore should be continued. Since any public discussion on the topic was taboo, the women did not have the opportunity to ask religious leaders their opinion, merely assuming that they supported this tradition.

For the most part, Tostan found that the religious leaders themselves were unaware of the serious health consequences linked to FGC and therefore gave little consideration to the matter. Because the topic was never brought to their attention in those terms by the women most concerned, they simply ignored the practice and never discussed it.

The Tostan education program helped to foster understanding and informationsharing between the women and the religious leaders in participating villages by encouraging discussion of these seldom discussed topics. Tostan realized at a very early stage in the implementation of our program that it was essential to work in collaboration with the local and national religious leaders. Religious leaders had always been open, helpful and supportive of our educational efforts in the villages. The fact that a leading and highly respected marabout, Serigne Mansour Sy of Tivaouane (now the Khalifa General of the Tidianes), was willing to serve as the sponsor of the Girls' Education Program and that an Imam was a trainer on the Tostan staff, helped villagers realize the respect and consideration Tostan holds for religious leaders. All materials are discussed with religious leaders before they are published and their ideas are not only taken into account, but often quoted as part of the educational sessions. This lends credibility to subjects covered in the program for participants.

When the Malicounda women decided to make a public declaration, Tostan invited the local religious leaders to attend the event and speak with the journalists. The women repeatedly referred to the opinion of the Imam who counseled them in making their decision. The television news journal showed the marabout and explained his position. This helped to influence others around the country.

When Demba Diawara, the Imam from the village of Keur Simbara started his campaign to end the practice among his own family in 10 villages near Joal, the fact that he is a religious leader and highly respected in the family and community made an enormous difference to the people he visited. He explained the position of Islam related to FGC and showed how continued fear of being attacked hy "spirits" for speaking of the negative consequences of the practice was contrary to the teachings of Islam. This seems to have been a major factor in the decision of these villages to end FGC on February 14, 1998.

At the Diabougou Declaration for 13 Bambara villages, a highly respected religious leader for the Bambara people in Senegal, Sidi Kounta, spoke to the participants at the meeting and explained that Islam did not require women to practice FGC. After having listened to the presentation by a local health worker on the dangers of FGC, he proclaimed that Islam was more interested in protecting people's health and promoting good health practices, not ones that could harm girls and women. His position was reinforced by other marabouts and Imams present at the meeting. Their opinions greatly influenced the participants' decision. 
A highly respected religious leader, Serigne Ibrahima $\mathrm{Ba}$, was present at the Medina Cherif Declaration on June 2 and 3. He made a powerful statement rejecting the idea that FGC was an obligation for Muslim women. This marabout hasweight in the Kolda region and his support of the women's decision to end FGC was a major factor in the defense of their decision.

\section{THE IMPORTANCE OF PUBLIC DECLARATIONS}

The public declaration of the women of Malicounda caused a national stir around the subject of Female Genital Cutting in Senegal. Here were village women who practice the tradition themselves, standing up before 20 journalists to announce why they had decided to end FGC in their community. The debate around the issue would never be the same. The Senegalese public now began looking deeper into the issue and started openly discussing and questioning FGC in the months that followed. New articles on FGC appeared in the newspapers, and several radio shows invited listeners to telephone in for the first time to give their viewpoints on the subject. Some people were relieved and happy to see the end of a controversial tradition that often leads to suffering; others were angry and suspicious that the women were "paid off" with money or projects.

When there was more positive media coverage on the Diabougou Declaration in February 1998 and it was reported that more than 8,000 villagers had now joined a movement to end FGC in their communities, the impact was even greater. Not just one village, but 12 other villages publicly declared an end to the tradition! During the same month, the President of Senegal announced the proposal for a law to abolish FGC in his weekly meeting of ministers. Once again there followed newspaper articles, TV coverage and radio broadcasts on the subject of FGC. Then in May, 1998 when the villagers in Kolda told Tostan of their decision to end FGC and asked for a meeting with all the villages concerned to make a common commitment, Tostan immediately agreed. Nonetheless, they met to discuss the importance of these public declarations. Was this really the best strategy to use in ending FGC? Should they continue to support this type of meeting or spend very limited financial resources on educational activities with new villagers? They were uncertain and hesitated.

Fortunately, during the month of June, Molly Melching received a letter from Mr. Gerry Mackie, a Junior Research Fellow at Oxford University in England who had read about the Malicounda and Diabougou Declarations in the International Herald Tribune. Mr. Mackie had written an article for "The American Sociological Review" in December 1996, arguing that because Female Genital Cutting is a practice necessary for intramarriage within a given ethnic group, it will only end when everyone decides to end the practice together. His thesis was based on an equivalent practice in China, female foot binding, which lasted for more than one thousand years but ended quickly in the beginning of the 20th century. In this article, Mr. Mackie brilliantly demonstrates that public pledges to abolish the practice are what brought an end to foot binding in China and what could bring an end to FGC in countries which practice it. Mr. Mackie writes: 
" $\mathrm{FGC}$ is a matter of proper marriage and family honor. An individual in an intermarrying group that practices FGC can't give it up unless enough other people do too. FGC is a certain kind of 'Schelling convention': what one family chooses depends on what other families choose. To understand, imagine that there is a group that has a convention whereby audiences (at the cinema, at plays, at recitals) stand up rather than sit down. Sitting has been forgotten. Standing is both universal and persistent. An outsider comes along and explains that elsewhere audiences sit. After the shock of surprise wears off, some people begin to think that sitting might be better, but it would be better only if enough other people sit at the same time. If only one person sits, she doesn't get to see anything on the stage. If only one family abandons FGC, their daughter doesn't get married, because only unfaithful women lack FGC. However, if a critical mass of people in the audience can be organized to sit, even just a column of people who are less than a majority, they realize that they can attain both the ease of sitting and a clear enough view of the stage. This critical mass then has incentives to recruit the rest of the audience to sitting, and the rest of the audience has incentives to respond to the recruitment. Similarly, if a critical mass of people in an intramarrying group pledge to refrain from FGC, then the knowledge that they are a critical mass makes it immediately in their interest to keep their pledges, and in their interest to persuade others to join in, and after persuasion makes it in everyone else's interests to join them. Without an understanding of the underlying mechanism, the abrupt end of such an entrenched practice by means of a mere public declaration would seem to be nearly miraculous.

"A peculiar characteristic of a convention like this is that even if each individual in the relevant group comes to think that it would be better to abandon the practice, no one individual acting on her own can succeed. Each person could come to think that sitting is better than standing, but any individual sitting on her own would only make herself worse off. Enough people have to sit at the same time. One way to do this is to declare a public pledge that marks a convention shift. Every family could come to think that FGC is wrong, but that is not enough, FGC would continue because any family abandoning it on its own would ruin the futures of its daughters. It must be abandoned by enough families at once so that their daughters' futures are secured."

Tostan and UNICEF rejoiced upon receiving this article which plausibly explained what had been happening in Senegal over the past year, gave scientific credibility to the process and pointed to the necessity of continuing with the public declarations when requested by the villagers. Later events and further interviews with our participants confirmed the validity of Mackie's hypothesis. 


\section{LESSONS LEARNED}

The breakthrough in ending Female Genital Cutting in 31 villages in Senegal has led Tostan to promote a strategy for ending FGC in other areas of Senegal as well as in other African countries. This strategy includes four essential steps:

1) Basic Education

2) Public Discussion

3) Public Declarations

4) Media Campaigns

For each step, Tostan has learned lessons that could be considered for future programs.

\section{BASIC EDUCATION}

Education is the basis for the villagers not only being able to make the decision to end FGC founded on pertinent health information, but also to defend and promote this decision. The villagers from Mampatim in the region of Kolda who signed the Medina Cherif declaration but did not first benefit from the education program stated: "It is necessary for us to go through the Tostan program as soon as possible because our friends and relatives are asking us why we joined in the Medina Cherif declaration. Although we understood when our relatives from Medina Cherif explained the negative health consequences to us, we are not ourselves able to explain this to others. The Tostan program will allow us to be able to do this."

Certain essential elements of the Tostan basic education program are key to the process of ending Female Genital Cutting:

-Tostan uses an integrated, holistic approach in the program. The program does not have the end of FGC as a specific objective;

-Tostan never tells villagers what to do, but presents credible facts and procedures for uninhibited deliberation where participants can make their own decisions;

-The facilitators do not condemn the participants or accuse them of being violent, uncivilized, brutal or barbaric; rather they are understanding and sympathetic about the importance of the tradition and the reasons for the women practicing it. They are particularly careful to never ask the women to stop, emphasizing that they are the ones who need to make decisions;

-Explicit arguments related to improving sexual pleasure for women were not helpful in ending FGC, particularly in public meetings; to the contrary, it made many women defensive and reactive. Tostan found it best to emphasize the negative health consequences and the right to the highest standard of health as the most effective arguments for discussions with men, women and children;

-Villagers learn other relevant information and skills in the program which help them in making important and profound changes in their communities: human rights, 
leadership, problem-solving, decision-making, negotiation, and confidence-building;

-The Tostan program emphasizes finding peaceful and non-aggressive solutions to community problems. The women feel comfortable with this approach and the men are more open and tolerant when included in the process;

-The program provides facilitator training needed for conducting the sessions in a participatory fashion, allowing for authentic dialogue and debate in the classroom;

-The program reinforces positive cultural values and traditions;

-The program allows for rehearsal and preparation of participants in presenting and defending information learned in the classroom through rolc-play, theater, song and poetry;

-Another important aspect of the program is the reputation that Tostan has in the villages for dependability, credibility and placing the village participant at the center of the program.

\section{PUBLIC DISCUSSION}

Important topics affecting the well-being of the community can not be limited to the classroom and need to be presented by the participants themselves for public debate and deliberation. Participants need skills for discussion of important issues with community members including traditional and religious leaders, their husbands and other men, women, and children. The presence of outsiders at these initial meetings is not desirable according to villagers interviewed. However, Tostan reinforced and facilitated public discussions by sending members of the same ethnic group, religious leaders, health agents and villagers who have already made the decision to end FGC to other villages. The Imam of the village of Mampatim in Kolda relates that he had already listened to radio programs broadcast from Guinca featuring influential Imams who denounced the tradition. "I was very worried to hear of the negative health consequences," he says, "but had no idea of what to do to bring an end to the practice in my village. Luckily, the villagers from Medina Cherif held a public meeting here to tell us of their decision to end FGC and we saw this as our opportunity to join in and stop ourselves."

Tostan has learned that during the public discussions, it is important to emphasize the following:

\section{Negative health consequences of FGC}

"We are not fighting against a tradition, we are fighting for girls' and women's health!" has been a popular slogan at the public meetings. During these meetings, personal testimonies of women, men and traditional cutters is very powerful. Often fellow villagers are unaware that certain health problems are linked to the practice of FGC and hearing of daughters and friends who have had serious health problems after the ceremony or during childbirth helps make people conscious of the dangers, often for the first time. Demba Diawara states that at the first meeting in a village, all the women will inevitably say there have never been any problems with FGC. He then gives examples of other women they know who have had problems and then one woman in the group will eventually say: "Oh! That happened to me too!"

"Once the door has opened, more and more stories come out!" he told us. 


\section{Religious opinions on FGC}

Inviting respected religious leaders to intervene in these meetings is one of the most important functions of the public meetings. Obviously, it is important to discuss the issues with the leaders before the meeting and include them in planning sessions.

Demba Diawara has also brought up traditional religious beliefs (taboos, spirits, etc.) relating to FGC and led debates on this with villagers. This has helped to demystify certain beliefs and superstitions that were keeping the women from talking about the subject.

\section{Presentation of previous declarations}

The villagers of Medina Cherif used the Diabougou Declaration which Tostan had translated into Pulaar at their meetings. This helped to show that they are not the only group discussing the consequences of this practice and making important decisions about ending it as a community.

\section{PUBLIC DECLARATIONS}

When a group of villages from the same ethnic group are thinking of ending FGC, it is important for them to meet to discuss the issue as an extended community. The two day meetings can be organized by the villagers themselves with some assistance from outside organizations to cover costs of transportation, food and lodging. In both the Diabougou and Medina Cherif seminars, the villagers chose who would do the presentations and also chose the health workers and religious leaders they felt were most convincing. For the Diabougou Declaration, the villagers invited the lawyer Sidiki Kaba, president of the Organization for Human Rights in Senegal, himself a Bambara, to discuss human rights in relation to the practice of Female Genital Cutting.

The government also sent representatives to these meetings including the Director of the Cabinet of the Ministry of the Family, Social Action and National Solidarity, Chiekh Tidiane Diop. He spoke of the strong position the government has taken concerning FGC and the new law to abolish FGC in Senegal. His presence was highly appreciated by the villagers.

Having a public health agent whom the villagers know and trust present at these meetings to make a brief and simple presentation as well as to answer questions is extremely important. Tostan also learned that it is preferable not to have the health worker present explicit drawings of sexual organs at these meetings. Such drawings are more acceptable in the classroom where the participants are accustomed to these type of diagrams.

The information officer of UNICEF, Henrictte Alavoc, also carefully selected members of the press to attend the declarations and prepared informational materials and briefing sessions before the trip. It is important that some of the radio broadcasters be of the same ethnic group and interview the participants in national languages. These radio programs can make a decisive impact on other communities around the country. Ms. Alavoe created press kits and a brochure on FGC that was distributed in large numbers. These materials were culturally sensitive and once again did NOT 
present sexual organs, blood or girls being cut or crying. Rather a positive image of happy mothers, fathers and children proclaimed they had chosen health and human rights over practicing FGC.

UNICEF also invited a delegation from Mali to attend the Medina Cherif declaration. The Malians were enthusiastic about the experience and called for future exchanges between the two countries.

During the public declarations, the women who had already undergone FGC and can do nothing about it now, were also assured that they will not be shamed or ridiculed in the future. As Demba Diawara notcs: "If this happens, it's the tongues that should be excised!" The older women interviewed told us this was particularly important for them.

Most important, participants felt that this was not an attempt to destroy tradition, it was a desire to promote and protect girls' and women's health as well as their human rights.

\section{MEDIA CAMPAIGNS}

The media has a decisive role to play in the process leading to the abandonment of FGC. Coverage of public declarations, interviews with religious leaders, health workers, and women and men who have already abandoned the practice, talk shows where the public can express their viewpoints and articles in local newspapers are excellent ways of provoking dialogue on the issue. It is particularly important to identify people who understand that certain of their own or their daughters' health problems are linked to FGC. Sharing their experiences with a large audience on the radio, in newspaper articles and on television can have a powerful effect on people who might otherwise defend FGC in the name of tradition. Courageous people such as Ourèye Sall who speaks openly of the near death of her daughter, Fatou Kiné Diawara who laments the psychological state of her great niece, D.B. who admits the death of girls during cutting ceremonies, D.D. who discusses how her sterility may be due to an infection following her operation and I.N. who deplores his wife's horrible suffering during the first weeks of their marriage, all helped to convince thousands of others that there are indeed real health dangers related to the practice of FGC.

It would nonetheless be beneficial to provide short training programs for newspaper, radio and television journalists to help them better understand the complexities of the issue and more effectively participate in the educational process.

Tostan believes that a national law prohibiting FGC can also be a deterrent when all of these three activities have taken place. In this way, social transformation comes about peacefully working for and not against those who practice FGC. As Gerry Mackie so aptly states: "The people who do FGC are honorable, upright, moral people who love their children and want the best for them. That is why they do FGC, and that is why they will decide to stop doing it, once a safe way of stopping it is found." 


\section{TOSTAN STAFF MEMBERS}

Molly Melching

Abdoulaye Thiam

Bilal Ndiaye

Dieynaba Dieng

Mohamed Basse

Maïmuna Kane

Malick Gueye

Meïssa Dieng

Ramata Dia

Khalidou Sy

Seydou Baldé

Malick Pouye

Madiakner Mboup

Cheikh Omar Ndiaye

Samba Sy

Magueye Ndiaye

Saliou Badiane

Ramatoulaye Diop

Mamadou Diallo

Abdoulaye Kandé

Ousmane Ndiaye

Cheikn Traoré

Oumar Nam
Abdourahmane Diallo

Abou Amel Camara

Abou Diack

Boussan Diaw

Guelel Djigo

Awa Fall

Mareem Dieng

Binta Thiam

Abdou Aziz Sy

Abdoulaye Baldé

Chiekh Diouf

Abdoulaye Cissé

Modou Gueye

Bara Kébé

Touty Dieng

Momadou Diouf

Mansour Sow

Djibi Sow

Moustapha Sall

Djibril Dramé

Ousseynou Traoré

Fatimata Barry 
